Agent-Based Computational

Transaction Cost Economics 
Publisher: Labyrint Publication

P.O. Box 662

2900 AR Capelle a/d IJssel

The Netherlands

Fax: $+31(0) 102847382$

Printed by: $\quad$ Ridderprint, Ridderkerk

ISBN 90-72591-79-8

Copyright (c) 2000 by Tomas B. Klos

All rights reserved. No part of this publication may be reproduced, stored in a retrieval system of any nature, or transmitted in any form or by any means, electronic, mechanical, now known or hereafter invented, including photocopying or recording, without prior written permission of the copyright owner. 
Rijksuniversiteit Groningen

\title{
Agent-Based Computational Transaction Cost Economics
}

\author{
Proefschrift \\ ter verkrijging van het doctoraat in de \\ Bedrijfskunde \\ aan de Rijksuniversiteit Groningen \\ op gezag van de \\ Rector Magnificus, dr. D.F.J. Bosscher, \\ in het openbaar te verdedigen op \\ donderdag 6 juli 2000 \\ om 16.00 uur
}

door

Tomas Benjamin Klos

geboren op 25 augustus 1970

te Apeldoorn 
Promotores:

Prof. dr. B. Nooteboom

Prof. dr. R.J. Jorna

Beoordelingscommissie:

Prof. dr. H.W.M. Gazendam

Prof. dr. N.G. Noorderhaven

Prof. dr. A. van Witteloostuijn 
Aan Marlies 


\section{Contents}

$\begin{array}{ll}\text { Preface } & \text { ix }\end{array}$

$\begin{array}{lr}\text { Introduction } & 1\end{array}$

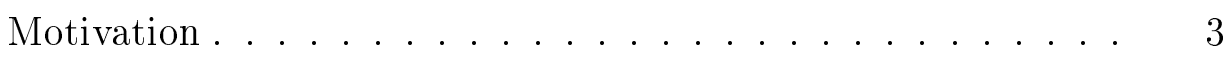

Organization of the Book ................ 4

1 Theoretical Background $\quad 7$

1.1 Transaction Cost Economics . . . . . . . . . . 8

1.1.1 Behavioral Assumptions ............ 11

1.1.2 Characteristics of Transactions ........ 12

1.1.3 The Argument . . . . . . . . . . . . . 15

1.2 Extensions . . . . . . . . . . . . . . . . . . 17

1.2 .1 Trust .................... 17

1.2 .2 Matching ................ 20

2 An Agent-based Approach 23

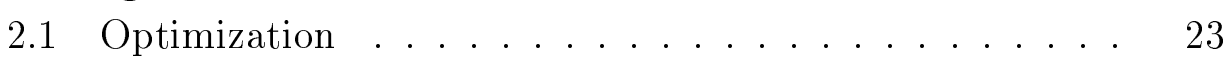

2.1.1 Economic Natural Selection . . . . . . . . 24

2.1.2 Objections against Optimization . . . . . . . . 25

2.2 Agent-based Computational Economics . . . . . . . . 35

2.2.1 Complex Adaptive Systems . . . . . . . . 38

$\begin{array}{lll}2.2 .2 & \text { Agent-based Computational } & \\ & \text { Transaction Cost Economics . . . . . . . . } 39\end{array}$ 
3 The Simulation Model $\quad 41$

3.1 The Main Loop . . . . . . . . . . . . . . 41

3.2 Preferences: Profit, Trust and Loyalty . . . . . . . . . . 43

3.2.1 Scores and Loyalty . . . . . . . . . . . . 44

3.2 .2 Profitability . . . . . . . . . . . . . . 46

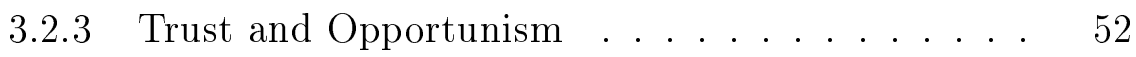

3.3 Matching ..................... 53

3.3.1 The DCR Algorithm . . . . . . . . . . . . 55

3.3.2 An Example Application . . . . . . . . . . 56

3.3.3 Matching Buyers and Suppliers ....... . 57

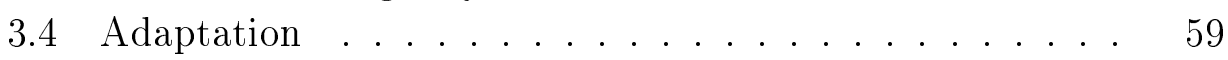

3.4.1 Choosing $\alpha$ and $\tau \ldots \ldots \ldots \ldots . \ldots . \ldots 59$

3.4 .2 Updating ................. 60

3.5 Summary ........................ 61

4 Results $\quad 65$

4.1 Priming the Model . . . . . . . . . . . . . 66

4.2 Adaptive Economic Organization . . . . . . . . . . 70

4.3 Optimal Outcomes? . . . . . . . . . . . . . . . . 74

4.4 Adaptive Agents . . . . . . . . . . . . . 78

4.5 Alternative Initialization . . . . . . . . . . 82

5 Discussion $\quad 85$

5.1 Conclusions . . . . . . . . . . . . 85

5.2 Discussion . . . . . . . . . . . . . . . 86

5.3 Further Research ............... 88

$\begin{array}{ll}\text { Appendices } & 91\end{array}$

$\begin{array}{ll}\text { A Genetic Algorithms } & 91\end{array}$

B The Simulation Program $\quad 93$

B.1 Agent-Based, Object-Oriented Programming . . . . . . 93

B.2 Specification .................. 94 
CONTENTS

C Parameters and Variables 103

$\begin{array}{ll}\text { Bibliography } & 105\end{array}$

$\begin{array}{ll}\text { Summary } & 113\end{array}$

Samenvatting (Summary in Dutch) 119 


\section{List of Figures}

1.1 Efficient boundary (adapted from: Williamson 1981a) . . 9

2.1 Outcomes in Miller's (1996) experiment . . . . . . . . 30

2.2 Tit-for-tat as a Moore machine .......... . 31

3.1 Buyers are assigned to suppliers or to themselves . . . 43

3.2 Efficiency due to scale and experience . . . . . . . 51

3.3 Flowchart of the simulation ........... 63

4.1 Initial score-differentials . . . . . . . . . . . . 72

4.2 Proportion 'made' (as opposed to 'bought') . . . . . . . 73

4.3 Buyers' profits . . . . . . . . . . . . . . . 75

4.4 Buyers' normalized profits . . . . . . . . . 76

4.5 Buyers' normalized profits in 25 individual runs . . . . . 77

4.6 The 12 buyers' adaptive learning in the space of $\alpha$ and $\tau \quad 79$

4.7 The 12 buyers' normalized profits and weighted average $\tau \quad 80$

4.8 Buyers' adaptive learning in the space of $\alpha$ and $\tau \ldots . \quad 81$

4.9 Different ways of initializing strengths . . . . . . . . . 82

4.10 Buyers' adaptive learning from various initial positions . 83 


\section{List of Tables}

1.1 Governance strucures and transactions . . . . . . . 16

2.1 The Prisoner's Dilemma . . . . . . . . . . . 28

3.1 Example preference-rankings . . . . . . . . 56

4.1 Parameters and variables used in the simulation . . . . 68

4.2 Initial score-differentials . . . . . . . . . . . 71

C.1 Parameters and variables allowed in the simulation ... 103 



\section{Preface}

At this point, I would like to thank a number of people who have worked with me on this thesis in one way or another. First of all, I want to thank Bart Nooteboom and René Jorna. Bart saw the potential of Agentbased Computational Transaction Cost Economics long before it was called that. I am grateful for his trust in my competence to carry out this project, which was sometimes even greater than my own. Working with him is so stimulating that the thought of doing that more often is almost enough to make me return to the academic world. As a cognitive psychologist, René's background is rather different than Bart's as an economist and mathematician; together they have made things really difficult-I mean interesting - for me; René's complementary perspective has been most valuable for me and for the project, and I thank him for his contributions. It consider it an important achievement that this thesis satisfies them both - a tangible result of our collaboration.

I want to thank Rob Vossen for all his contributions. It has always amazed me how he was able to give insightful comments and suggestions on topics I did not think he was familiar with. He also never got tired of supplying me with the necessary diversion. I also thank him and Bob Blaauw for being my 'paranymphs'. I would also like to thank Henk Gazendam, Niels Noorderhaven and Arjen van Witteloostuijn for their efforts as members of the dissertation committee and for the just-in-time delivery of their comments.

There have been many colleagues at the faculty of Management and Organization and various other faculties of the University of Groningen, who have contributed to my undertaking in various ways. In particular- 
and in alphabetical order-I would like to mention Maryse Brand, Hans van den Broek, Gerda Gemser, Constantijn Heesen, Vincent Homburg, Gjalt de Jong, Fieke van der Lecq, Delano Maccow, Han Numan, Gábor Péli, Wouter van Rossum, Michel Wedel, Wout van Wezel and Frans Willekens. Outside the University of Groningen, I have enjoyed and benefited from my contacts with Han La Poutré and David van Bragt at the Center for Mathematics and Computer Science in Amsterdam. Outside the Netherlands, Leigh Tesfatsion at Iowa State University and Kathleen Carley and John Miller at Carnegie Mellon University have been very helpful. I also want to thank Christina Dorfhuber and Curt Topper for putting me up (and putting up with me) during my visit to Carnegie Mellon University.

I am grateful to the Dutch Organization for Scientific Research (NWO), the Graduate School and Research Institute SOM, the Interuniversity Center on Social Science Theory and Methodology (ICS), and the Santa Fe Institute for their generous financial support that made it possible for me to attend various conferences and undertake several other travels and activities. I want to thank colleagues at those conferences, and especially the class of '97 of the Santa Fe Institute Summer School on Computational Economics.

Finally, I owe so much to Marlies that I find it hard to express this in words. I hope that dedicating this book to her makes it clear how much she means to me.

Tomas Klos

Groningen, May 2000 


\section{Introduction}

"It is the process of becoming rather than the never-reached end points that we must study if we are to gain insight."

(Holland 1992, p. 19)

This thesis deals with processes and outcomes of organizing, building on an economic organization theory, transaction cost economics. Organizing refers to the adoption of structural forms for coordinating activities: how are activities distributed and coordinated within and between firms? Which firms perform which activities and how are the interfaces between them organized? Transaction cost economics is an economic theory that analyzes outcomes of organizing directly: which organizational forms are the most appropriate, i.e. 'economic', under given circumstances? The hypothesis is that these are also the forms to be found in reality because firms not using these forms will not survive and will be forced to switch to the appropriate ones. In this thesis, a variety of arguments against this assumption are brought forward and a different approach is used to come up with statements about the organizational forms to be found in reality. Focusing on the process of organizing - and on outcomes only indirectly - this thesis develops a theory of 'adaptive economic organization'. Rather than from a rational analysis of which organizational forms are most appropriate for organizing different types of transactions, statements are derived from computer simulations of the process in which firms adaptively learn to organize transactions.

Transaction cost economics (Coase 1937, Williamson 1985) is concerned with the organization of 'transactions' of goods or services be- 
tween stages of activity, and yields propositions about which organizational forms are appropriate for which types of transactions. Simply put, two consecutive stages might be brought together within a single firm, using hierarchy to organize transactions between the stages; or the different stages could be distributed across separate, specialized firms, using the market to organize transactions between them. In the first case, the benefits from trade (specialization, economies of scale) are not fully exploited, but the coordination of the transaction is easier and therefore less costly, because both sides of the transaction fall under the supervision of a common superior, who can design and impose the terms of the transaction in a way that is optimal for the firm as a whole. In the second case, the parties on both sides of the transaction are specialized firms who may produce more economically, but they are also autonomous and may have conflicting interests, so that the terms of trade will be costly rather than easy to design and enforce in their mutual interest.

According to transaction cost economics (henceforth TCE), the decision between these alternatives is made by 'aligning' organizational form ('governance') with the attributes of the transaction to be organized in such a way that the total of production and organization costs is minimized, i.e. in an economic way. Given the characteristics of a transaction, certain organizational forms are more appropriate for organizing the transaction, in that they lead to lower total costs. The theory hypothesizes that the most appropriate organizational form will be used for organizing the transaction. It also assumes that individual economic agents are boundedly rational as well as potentially opportunistic. The first of these two behavioral assumptions means that it is very hard-if not impossible - to design the terms of a transaction between autonomous contracting parties in such a way that all possible future contingencies are covered. First of all, not all information about events in the future is available and secondly, were that information available, it is typically still impossible, due to limited capacity for processing information, to perform the task of designing an appropriate contract that prescribes optimal actions to be taken in the event of each contingency. The condition of bounded rationality could be a problem because of the second assumption (that people are potentially opportunistic), which says that 
people pursue their self-interest with guile. People can not be blamed for pursuing their self-interest, and the fact that they do is not a problem by itself, if all relevant information-including that obtained from the contracting partner - can be used to design measures to counter negative effects of the partner's pursuing his self-interest. The fact that people seek self-interest with guile means that they distort the truth and disguise and withhold facts, which makes designing counter measures more difficult and costly, or even impossible.

\section{Motivation}

Transaction cost theory contains a rational analysis of which organizational forms are optimal for different types of transactions, given that agents are boundedly rational and possibly opportunistic. It is then hypothesized that these optimal organizational forms are the ones to be found in reality: boundedly rational agents are hypothesized to use organizational forms that result from a rational analysis, which they are explicitly assumed to be unable to carry out. The argument underlying this (seemingly?) contradictory hypothesis - as well as many others in economic science more generally - is that suboptimal organizational forms are presumed to be selected out by market forces; agents using them allegedly do not survive this 'struggle for profit' (Friedman 1953). ${ }^{1}$ In economics, therefore, it is irrelevant whether or not people are able to determine what is optimal - their behavior will be consistent with that anyway, because if it is not, it will not survive. What is relevant, is that economists themselves are able to determine which behavior is optimal, because it gives them their hypotheses.

Putting it this bluntly may seem somewhat antagonistic and it is also not altogether fair. It really does not matter whether hypotheses about boundedly rational agents are derived from a rational, formal analysis

\footnotetext{
${ }^{1}$ This presumption is often illustrated with Friedman's (1953) example of a billiards player who may never even have heard of the laws of mechanics, but will play as if he applied them to every shot, because he would never win if he did not play in such a way.
} 
or otherwise. What is at issue here, is whether the 'economic natural selection' argument that relates TCE's rational analysis to its main hypothesis, holds and whether, therefore, TCE's analysis is even relevant for the study of economic organization. In this thesis, it is suggested that for a variety of reasons (discussed in more detail in Chapter 2), this is not the case. Essentially, the market is not completely efficient as a selection mechanism; an evolutionary selection process does not eliminate all forms of behavior based on trust and cooperation, like TCE suggests (Williamson 1985); finally, an evolutionary selection mechanism is not even appropriate in the first place. As discussed in Chapter 2, there are several reasons why biological and economic natural selection can not be compared.

In this thesis, a different approach is therefore proposed to generate hypotheses about economic organization. This alternative approach is agent-based: it regards multiple, boundedly rational agents in each others' contexts and in principle allows all forms of behavior - suboptimal as well as optimal (although it really can not be established what optimal is, once a multitude of co-dependent agents are included in a model). Reinforcement learning is then attributed to the agents, and the whole system of agents is simulated on a computer to find out which organizational forms the agents learn to adopt.

\section{Organization of the Book}

For this alternative approach, we borrow some elements from transaction cost economics, but not its analysis. Furthermore, some extensions are required in order to be able to incorporate the influence of the other agents in each individual agent's environment. This is the subject of Chapter 1 that describes the theoretical background for the research. In Section 1.1, TCE's behavioral assumptions are discussed along with the attributes that can be used for describing and classifying transactions. On the basis of that discussion, although it is not used in this thesis, the theory's analysis is reproduced for the sake of readers not familiar with transaction cost economics. Theoretical extensions required to include the 
influence of agents in the environment are discussed in Section 1.2.

The main deviation from TCE lies in the process-approach that was taken, as discussed above. This is set out in more detail in Chapter 2. Rather than focus on the optimal outcomes of transaction cost economic reasoning and hypothesize that these outcomes are found in reality, the approach taken in this thesis is to focus on the process of organizing in order to be able to explain, predict and manage the outcomes that result from such processes. In Section 2.1, it is explained why (transaction cost) economics is not able to do this and why we think it is necessary. Also, a method is proposed that makes possible the study of outcomes as the result of and in relation to the processes that lead to those outcomes. Individual, boundedly rational agents (firms) are confronted with problems of organization and are not given the apparatus of transaction cost economic logic to help them solve those problems. Instead, they are assumed (and therefore enabled) to organize adaptively, in a process of learning which organizational forms work well and which do not. This may or may not lead to their adopting transaction cost economic organizational forms - although the process is, in principle, not even assumed or required to ever settle down to a stable state in the first place-just like firms in reality rarely 'align perfectly'. Instead of searching for outcomes that firms may never use, therefore, for a variety of reasons discussed in the chapter, we propose to use computer simulations to model and reproduce the process by which agents adaptively search for satisficing - rather than optimal - organizational forms, to generate alternative hypotheses about which forms economic agents (come to) use.

The computer simulation model that is used is presented in Chapter 3. It includes a number of buyers and suppliers who interact with each other in a number of timesteps. In each timestep, the buyers are faced with the problem of organizing a particular transaction. They may organize it within their own firm, or in a relation with a supplier. All agents' choices together determine the 'payoff' that each of them receives. In subsequent timesteps, choices that yielded higher payoffs are more likely to be made again, while choices that returned lower payoffs are likely to be abandonded. The simulation model is described at a relatively abstract, implementation-independent level; the details of the 
actual implementation are described in Appendix B.

The results of experiments with the simulation model are presented and discussed in Chapter 4. A number of variables in the model were varied and the effect on the outcomes of the simulation are analyzed and discussed. Overall conclusions are drawn and discussed in Chapter 5, along with limitations of the current approach and suggestions for further research. 


\section{Chapter 1}

\section{Theoretical Background}

This chapter presents the theoretical background for the thesis. This theory deals with the organization of transactions that occur between successive stages of activity. For example, components have to be brought from where they are produced to where they are assembled into a finished product, iron ore or coal has to be transported from the mine to the smelter to the steel producer, and knowledge has to be transported from where it is created (using money) to where it is used (to make money). The phrase 'successive', by the way, is not used to suggest that only vertical relations are implied, but simply that one activity happens before another; these may be different activities at the same level between different firms (in cooperative $R \& D$, for example), yielding a horizontal relation.

In any case, goods and services have to be transferred from one stage to another. The main substantive theory used here is transaction cost economics, which says what the best structural form is for organizing such transfers. For example, both stages might be brought together within the bounds of a single firm - i.e. vertically integrated - or put in separate firms, using the market to organize transactions between them. A company might own its own $\mathrm{R} \& \mathrm{D}$ department, or outsource research work to a specialized institute. Depending on the characteristics of the transaction, some organizational forms are more appropriate than others. Transaction cost economics is about finding the most appropriate-i.e. 
the economic - organizational form for a given transaction.

Transaction cost theory is described in Section 1.1. The approach used in this thesis requires certain substantive extensions, described in Section 1.2. These will be shown to supplement transaction cost economics in a very natural way. Methodological issues, on the other hand, are discussed in Chapter 2, where objections are raised to the approach taken in TCE, and where the alternative approach that was taken in this research is presented.

\subsection{Transaction Cost Economics}

Transaction cost economics says which structural form should be used for organizing a given transaction. "A transaction occurs when a good or service is transferred across a technologically separable interface. One stage of activity terminates and another begins" (Williamson 1981a, p. 552 ). Rather than focus on individual stages of activity - viewing the firm as a production function to be optimized-TCE focuses on transactions between stages of activity and views the firm as one of the organizational forms that may be used to organize such transactions.

Figure 1.1 shows an example. The figure shows a firm whose technological core consists of three stages of production, S1, S2, and S3. These are the firm's core activities and - in the example - it 'always' performs those itself. Raw materials production is R, which, likewise, the firm has decided 'never' to perform itself, and distribution of finished products is D. This is not to say that the firm will indeed always perform each of the productive stages $\mathrm{S} x$ itself, but it will in the context of the example, in which this is not at issue. More generally, all such decisions about which activities a firm performs will eventually have to be justified in terms of transaction cost economic reasoning.

Each stage of production $\mathrm{S} x$ uses a component $\mathrm{C} x$, which has to be produced. The choice exists for the firm to produce the component itself (Cx-M for make) or to let a specialized outside supplier produce it ( $\mathrm{C} x-\mathrm{B}$ for buy). The same applies to distribution D, which is D-M if the firm owns distribution and D-B if the firm uses market distribution. Each of 


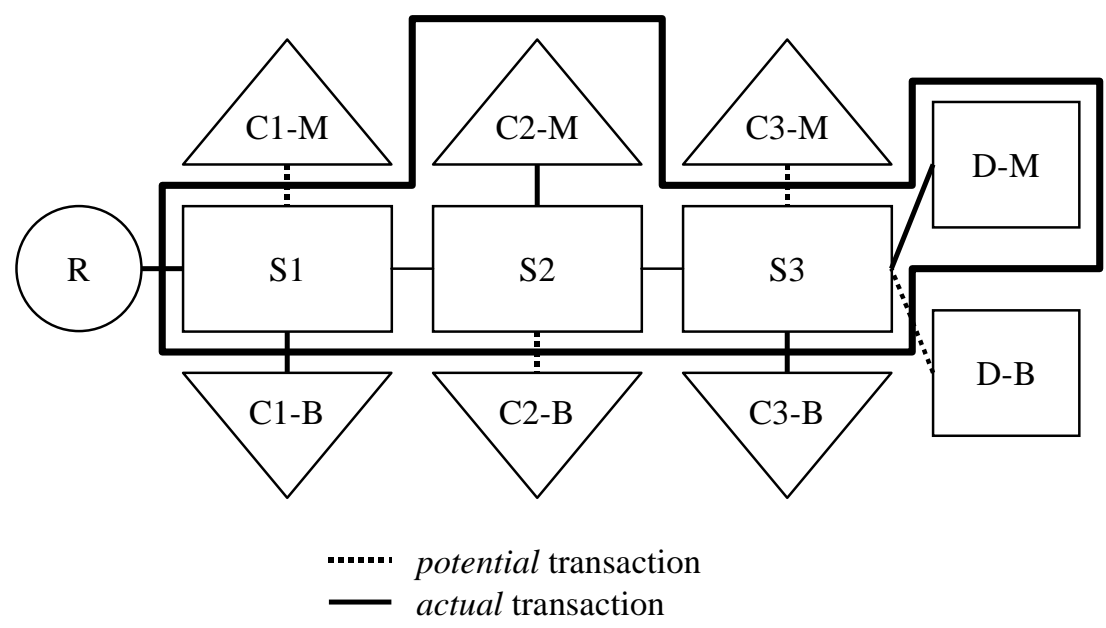

Figure 1.1: Efficient boundary (adapted from: Williamson 1981a).

the four transactions $\mathrm{C} x-\mathrm{S} x(x=1,2,3)$ and $\mathrm{S} 3-\mathrm{D}$ might be organized within, as well as across the firm's boundary, which is the thick black line. In this particular case, the decision has been made to make $\mathrm{C} 2$ and to also keep distribution in-house, and to buy components $\mathrm{C} 1$ and C3. Transactions $\mathrm{C} 2-\mathrm{S} 2$ and $\mathrm{S} 3-\mathrm{D}-\mathrm{M}$, therefore, are organized within the firm's boundary, while transactions $\mathrm{C} 1-\mathrm{S} 1$ and $\mathrm{C} 3-\mathrm{S} 3$ are organized across the firm's boundary, i.e. on the market.

Transaction cost economics is a theory about this mapping of organizational forms onto transactions. TCE originated in Coase's (1937) paper The Nature of the Firm, in which he set out "to discover why a firm emerges at all in a specialised exchange economy" (Coase 1937, p. 390 ); in other words, "in view of the fact that it is usually argued that coordination will be done by the price mechanism, why is such organisation necessary?" (1937, p. 388). Coase based his answer on the recognition that the transaction should be the unit of analysis and that firms and markets are alternative organizational forms that can both be used for organizing a transaction. According to Coase, then, firms exist because there are costs of using the price mechanism that market-organization 
relies on. ${ }^{1}$

Transacting on the market requires, for instance, that prices are established and that contracts are designed. Some or all of these costs can be reduced or even eliminated when firm- is substituted for marketorganization. Instead of having to conclude a separate contract for each transaction to tell the parties involved what to do under which circumstances, both parties agree to obey the directions of an entrepreneur or hierarchichally superior manager, who decides on those directions in the interests of the firm as a whole. Were the parties separate and autonomous, each would want to decide on the various terms of the contract in his own interests. The resulting costs of negotiating ('haggling') and designing contracts in this manner are transaction costs and some of them can be avoided by using firm-organization. This is how different organizational forms influence transaction costs, so the question "why co-ordination is the work of the price mechanism in one case and of the entrepreneur in another" (Coase 1937, p. 389) can be explained by relating characteristics of transactions to the costs of those transactions when organized using each possible organizational form. For different transactions, different organizational forms will best be able to economize on those costs, which is why organization will be the work of the price mechanism in one case and of the entrepreneur in the other.

Coase's work was carried further-among others ${ }^{2}$ and mainly-by Williamson $(1975,1985)$, who gives a thorough analysis of the characteristics of transactions and of the way they influence the abilities of different organizational forms to economize on the costs of transactions. Furthermore, Williamson included the effects of the characteristics of human decision makers within organizations on ex post transaction costs, next to the ex ante transaction costs that Coase (1937) focused on. Ex ante

\footnotetext{
${ }^{1}$ Coase received the 1991 Nobel Prize in Economics "for his discovery and clarification of the significance of transaction costs and property rights for the institutional structure and functioning of the economy" (quoted from the website of the Nobel foundation at http://www.nobel.se/).

${ }^{2}$ Olson (1965, p. 12), for example, also writes about "economic organizations that are mainly means through which individuals attempt to obtain the same things they obtain through their activities on the market".
} 
transaction costs are the costs that have to be incurred before a transaction can occur; partners have to search and find each other, and they have to negotiate a contract. Ex post transaction costs are the costs that have to be incurred once the transaction is underway and the agents have committed themselves to it; they have to monitor the partner to ensure that he keeps up his end of the bargain and respond to unforeseen circumstances that may arise. What follows is a description of transaction cost analysis that is based mainly on the writings of Williamson. Section 1.1.1 discusses behavioral assumptions, Section 1.1.2 characteristics of transactions, and Section 1.1.3 outlines transaction cost economics' main argument.

\subsubsection{Behavioral Assumptions}

Decision makers' characteristics are summed up in the two 'behavioral assumptions' that - in Williamson's rendering - underlie transaction cost economics, namely that agents are boundedly rational as well as potentially opportunistic. ${ }^{3}$ Bounded rationality refers to the fact that people (agents) are intendedly rational, but only limitedly so. So although economic agents may want to choose optimally, they are typically unable to gather as well as process all the information required to make such decisions. Information about future circumstances will always be incomplete and the agent's cognitive architecture is limited in various ways. Moreover, certain classes of decision making problems themselves can be proven to be insoluble - even with unlimited processing capacity. Think

\footnotetext{
'The term 'agent' is used to refer to economic entities - people as well as firms. A firm's 'behavior', like decision making, is considered to be a function of the behavior of the human agents within the firm; those individuals' personal characteristics, like trustworthiness and general attitude towards the world, affect the resulting firm behavior - Ring and van de Ven (1994) make the distinction between characteristics of decision makers 'qua persona' and 'qua organizational role'. Although we abstract away from the actual individuals within the firm and also from the politics of intra-organizational decision making, we do let certain personal traits re-emerge at the firm-level, as the outcome of some kind of - not explicitly modeled-aggregation across all of the firm's constituents. See (Masuch and LaPotin 1989) for a model in which this micro-macro link is modeled explicitly.
} 
of the game of chess for an example. These are some of the considerations that underly the assumption of bounded rationality; a complete treatment of the issue is beyond the scope of this thesis.

Opportunism is self-interest seeking with guile. This goes beyond simple self-interest seeking to include "calculated efforts to mislead, distort, disguise, obfuscate, or otherwise confuse" (Williamson 1985, p. 47). It is not assumed that every agent is opportunistic all the time, or that all agents are opportunistic in the same degree; just that some are more prone to opportunism than others, and that this is impossible, with certainty, to judge ex ante. Opportunism will be discussed in more detail and in relation to trust in Section 1.2.1.

Bounded rationality implies (ex ante) incomplete contracting and potential opportunism implies (ex post) moral hazard. Were rationality unbounded, then it would not matter that agents could possibly act opportunistically, because any circumstance in which they would, could be dealt with in the (comprehensive) contract. If, alternatively, there were no opportunism, then it would not matter which circumstances would occur, because they would always be responded to in an honest and cooperative manner. Real contracting problems only occur, therefore, when bounded rationality and the possibility of opportunism are both allowed for, which TCE does.

\subsubsection{Characteristics of Transactions}

The dimensions relevant for describing and classifying transactions are uncertainty, frequency and-most importantly-asset specificity. The analysis of the role of asset specificity is one of Williamson's (and TCE's) main contributions to the study of economic organization (Williamson 1971, Klein et al. 1978); it will therefore be discussed first.

\section{Asset specificity}

Asset specificity refers to the specialization to a transaction of assets that were invested in to support it. To the extent that assets are specific to a transaction, sustaining the transaction during the period in which returns 
on the investments are generated, is a necessary condition for generating those returns. An example is the construction of an iron-ore smelter near a steel production plant. The advantage of locating the smelter near the plant is that the molten iron can quickly be transported to the steel mill without having to be re-heated. The value of the smelter in this sense, however, is much lower for other transactions, i.e. transactions between the smelter and any other steel mill located farther away. In order to obtain returns on the investment in the smelter, therefore, the transaction with this particular steel mill has to continue for a particular period of time, and the investor in the smelter will want to set up a contract to guarantee the sale of enough molten iron during that period, so as to generate sufficient returns on his investment in the smelter. The dependence, however, works both ways, since the steel producer will want to guarantee the delivery of molten iron that he does not have to re-heat himself.

Another often-used example concerns the mould that a car-door manufacturer has to invest in to support his transaction with a car producer for whom he produces doors. The mould can only be used to produce car-doors for the cars that this particular car manufacturer produces, so the transaction between these two parties has to exist for as long as the car-door manufacturer needs, to generate the required returns on his investment in the mould. If the relation breaks prematurely, however, the car manufacturer will also experience problems in the supply of car-doors for his particular model.

Specialized assets allow products to be differentiated and profit margins to be increased (this is dealt with in more detail in Chapter 3). Specialized assets also generate production cost savings as compared to the use of 'general purpose' assets (a smelter located nowhere near the steel mill). Beside these positive effects on costs and returns, what is important about asset specificity, is the limited ability to redeploy such specialized assets outside the transaction in which they were invested, should the contract execution period be interrupted or terminated prematurely. This poses the dilemma that savings may result from investments in transaction specific, rather than general purpose assets, while costs have to be spent on a contract, to protect the period required for 
generating returns on the investments, from ending prematurely as a result of the partner's opportunism. Transaction specific assets effectively lock the parties involved in an exchange into one another, and give them a rationale for investing in (the governance of) the transaction itself, so as to guarantee the successful completion of the contract, lest investments in specialized assets be lost.

\section{Uncertainty}

Uncertainty can be exogenous or endogenous. Exogenous uncertainty refers to the possiblity that circumstances arise during the contract execution phase, that were not foreseen at the moment the contract was drawn up, and to which the parties will therefore have to adapt the contract. This is where endogenous or behavioral uncertainty comes into play, which has to do with the fact that, at such moments, the partner may behave opportunistically.

The relevance of uncertainty is that if there is much uncertainty, there are many situations that may occur and that would require the partners involved in a transaction to adapt to. This is very expensive, and there are also many opportunities for agents to behave opportunistically. In principle, the higher the uncertainty surrounding the transaction, the more appropriate it is to organize the transaction internally rather than on the market. Within the organization, uncertainty can more easily be reduced, since authority can be used to exercise control over the activities of different agents within the organization. When different firms are involved, it is much harder to guarantee that the different sides of the transaction live up to their end of the contract.

\section{Frequency}

As Coase (1937) already noted, the frequency with which a transaction occurs matters. If a transaction occurs very often, it may be worthwhile to establish a specialized organizational form (i.e. a firm) in which to organize it, so as to economize on the costs of concluding separate contracts for each transaction on the market. If a transaction only occurs 
rarely, it is probably best to organize that transaction with another firm, because otherwise the other end of the transaction would also have to be organized within the firm. Such investments can simply not be recouped when they are only used infrequently.

\subsubsection{The Argument}

According to Williamson, "the central problem of economic organization" (Williamson 1996, p. 153) is adaptation: of governance to transactions. Transaction cost economics relates governance forms to transactions in a discriminating - mainly transaction cost economizing - way. The economizing capabilities of different forms of governance depend on the attributes of transactions described above, given that agents are boundedly rational and potentially opportunistic. TCE looks mainly at transaction costs, but in general, the trade-off should be considered between costs of governance (transacting and organizing) and of production: "[a] tradeoff framework is needed to examine the production cost and governance cost ramifications of alternative modes of organization simultaneously" (Williamson 1985, p. 61).

Because of the first of TCE's two behavioral assumptions - that agents are boundedly rational-contracts are necessarily incomplete, so that before the end of the period during which the transaction needs to be sustained in order to gain returns on investments in specific assets (if any), unforeseen contingencies may arise to which the parties will have to adapt. However, when separate, autonomous firms are involved, then because of TCE's second behavioral assumption - that agents are potentially opportunistic - this adaptation can not be assumed to be cooperative (i.e. in their mutual interest), but will rather result in costly haggling over the distribution of the unforeseen gains or losses (Williamson 1981a). If no specific assets have been invested in, then both parties can go their own way, but if transaction-specific assets have been invested in, then organizing the transaction between separate, autonomous, potentially opportunistic firms, will lead to costs of safeguarding returns on those investments. If those costs become too high, because assets are very specific, then organizing the transaction within a single firm's hierarchy 
economizes on those costs, because in that case, both parties belong to the same firm and will be more likely to have the same interests (those of the firm); otherwise, a (hierarchichally superior) manager will decide in the best interest of the firm.

This reasoning lead Williamson (1979) to the mapping depicted in Table 1.1. If assets are not specific, then they can easily be redeployed in

\begin{tabular}{|c|c|c|c|c|}
\hline & \multicolumn{3}{|c|}{ Investment Characteristics } \\
\hline & & Nonspecific & Mixed & Idiosyncratic \\
\hline \multirow{2}{*}{ 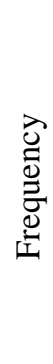 } & 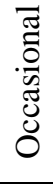 & $\begin{array}{c}\text { Market } \\
\text { Governance }\end{array}$ & $\begin{array}{r}\text { Trilateral } \\
\text { (Neoclassical }\end{array}$ & $\begin{array}{l}\text { Governance } \\
\text { Contracting) }\end{array}$ \\
\hline & 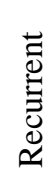 & $\begin{array}{l}\text { Classical } \\
\text { Contracting) }\end{array}$ & $\begin{array}{l}\text { Bilateral } \\
\text { Governance } \\
\quad \text { (Relational }\end{array}$ & $\begin{array}{c}\text { Unified } \\
\text { Governance } \\
\text { Contracting) }\end{array}$ \\
\hline
\end{tabular}

Table 1.1: Matching governance strucures with commercial transactions (adapted from: Williamson 1979).

another transaction. There is no need for specialized governance structures in this case, so, no matter what the frequency of the transaction, it can easily be organized on the market. Purchasing standard equipment or materials are examples of this type of transaction. When assets are specific in a non-trivial degree, there is an interest in seeing the contract through to completion. When such a transaction occurs only occasionally, setting up a specialized governance is too expensive, so a standard contract with the possibility of arbitrage by a third party such as a court should be used. When the transaction occurs frequently, on the other hand, investments in specialized governance are warranted, in the form of relational contracting. This can be in the form of bilateral governance of the transaction when asset specificity is not too high, but when it is, the benefits of specialization are not high enough to offset the cost of bilateral governance, so unified governance should be used in this case. 


\subsection{Extensions}

Although we agree with the usefulness of much of transaction cost economics' approach, there are two main points on which we disagree with it. These points are addressed in this thesis by means of an alternative approach, which we will argue will lead to better explanations and predictions of organization. The first is that, although TCE assumes that people are boundedly rational, its main hypothesis is that people will use those organizational forms that - given their and other people's bounded rationality - are aligned with the attributes of the transactions to be organized. The problem is that the alignment results from a fully rational analysis. So, it is hypothesized that boundedly rational individuals will behave as if they were rationally able to make this alignment. This issue and the way we deal with it is taken up in the next chapter.

The second problem we have with TCE lies in the fact that the market is suggested as one of the forms in which a given transaction can be organized, while the fact that a market has to be made before it can be used, is neglected. Someone who decides to use the market for organizing a transaction, will have to find a specific other firm to be on the other end of the transfer that the transaction is. Moreover, the decision is more appropriately framed as one among a number of alternative sources of supply, one of which is internal to the firm and some of which are external. Finding the most appropriate one among these alternative sources is a search problem, in which, even if it is assumed that the relevant characteristics of the internal source are known, alternative external sources (i.e. suppliers) differ among each other and there is more information available about some potential partners than about others. This issue is taken up in the current section. It will be treated under two headings, trust and matching, in Sections 1.2.1 and 1.2.2, respectively.

\subsubsection{Trust}

TCE's view on opportunism is based on the assumption "that some individuals are opportunistic some of the time and that differential trustworthiness is rarely transparent ex ante" (Williamson 1985, p. 64). In 
other words, since it is hard to tell who will be opportunistic and when, the possibility of opportunism is always reckoned with and measures to counter its effects are always necessary.

In regarding opportunism, it is instructive to make the distinction between room for and inclination towards opportunism (Nooteboom 1999b) and to consider that actual opportunism is a function of the two. In TCE, however, information about the potentially opportunistic party's inclination to behave opportunistically is not allowed to enter the analysis, simply because that would make it too complex (Williamson 1985, p. 59):

"[i]nasmuch as a great deal of the relevant information about trustworthiness or its absence that is generated during the course of bilateral trading is essentially private informationin that it cannot be fully communicated to and shared with others (Williamson 1975, p. 31-37) - knowledge about behavioral uncertainties is very uneven. The organization of economic activity is even more complicated as a result."

So, even though it is admitted that relevant information about trustworthiness is generated during the course of bilateral trading -information agents may use to reduce endogenous uncertainty - this information is not included in the analysis, because that would make the organization of economic activity to be explained too complicated. In this thesis, the suggested increase in the complication of the organization of economic activity is not admitted as a justification for not addressing it. On the contrary, it is proposed and subsequently shown that this complication can be dealt with using the appropriate apparatus. In particular, the consequences of incorporating relevant information about trustworthiness for the organization of economic activity will be explored by modeling 'the course of bilateral trading' explicitly and at the appropriate level-i.e., the level of the individual firms involved in bilateral trading. This allows us to incorporate the effects of the accumulation and subsequent use of 'relevant information about trustworthiness or its absence'. Furthermore, even if it is considered impossible to transfer this private knowledge, individuals will still use this private information about trustworthiness as 
input for their own decisions about the 'bilateral trading' they are involved in. Obviously, TCE does not go this way because that would require going down to the level of individual agents and their boundedly rational processing of the information. In this thesis, we will go that way.

The way in which the accumulation and use of relevant information is modeled, can be informed by theories of trust. Since "some individuals are opportunistic some of the time and (...) differential trustworthiness is rarely transparent ex ante" (Williamson 1985, p. 64), an agent's trustworthiness is equal to his not behaving opportunistically. In fact, an agent's trustworthiness is equal to his not wanting to behave opportunistically. This is where the distinction between room for and inclination towards opportunism (and that between exogenous and endogenous, or behavioral uncertainty) is relevant. This is also where the distinction between trust in intention and trust in competence can be explained (for a good overview of issues related to trust, see Nooteboom's (1999b, p. 24-35) discussion). In this thesis, we will be concerned only with trust in intention; agents are always assumed to be able to live up to other agents' expectations, so the question is always whether the agent wants to, rather than whether he is able to. If an agent's trustworthiness is equal to his not behaving opportunistically, then another agent's subjective interpretation of the probability of that trustworthiness, in turn, is that other agent's trust in the first agent; the second agent's subjective probability that something does not go wrong (Chiles and McMackin 1996, Dasgupta 1988, Gambetta 1988). It is interesting to see that transaction cost economics' main propositions correspond closely to those derived from a theory of trust (Deutsch 1973). In his 'trust problem in an exchange relationship'-modeled as a prisoner's dilemma (see Section 2.1.2) in which two players have the options to give or to retain their own item-Deutsch (p. 161) mentions "three fundamental ways to guarantee that an exchange will be reciprocated: (1) to employ arrangements that will make for simultaneity of giving and receiving in the exchange; (2) to use third parties; and (3) to use 'hostages' or 'deposits,' which will enable each person to commit himself to the exchange and to be convinced that the other person has also committed himself". The parallel with TCE's governance structures is obvious. To a large 
extent, both theories approach the same issues - just from different directions: TCE from the perspective of opportunism and Deutsch (1973) from the perspective of trust. In this thesis, they are both used in a complementary fashion.

\subsubsection{Matching}

The consequence of trust and of the fact that more relevant information about trustwortiness is generated during the course of some bilateral trading relations than others, is that agents have differential preferences for relations with different other agents. A convenient way of incorporating this fact is by using matching models (see (Roth and Sotomayor 1990) for an excellent introduction to and overview of matching theory). The seminal paper by Gale and Shapley (1962) uses marriage markets to illustrate the issues. ${ }^{4}$

Matching models are used to model and analyze situations where agents have to be assigned to other agents for certain interactions to proceed. For example, workers prefer working at some firms rather than at other firms, and firms will prefer some suppliers to others. The fact that agents will try to influence the outcome of the eventual assignment, has an effect on the outcome that results, and on its characteristics. This contrasts with standard economic theory where individual assignments are either not explicitly modeled but aggregated across, or assumed to be random or under the control of a central supervising agent (an auctioneer). When allowance is made for the fact that each agent will rather be involved with certain agents that with others, models can be made much more realistic, and predictions can be made for situations where this phenomenon occurs - for which many interesting situations qualify.

To get an idea of the range of possible applications, consider that Roth (1984) studied matching models of the market where medical students compete for internships at the best hospitals (and hospitals compete for the best medical students), Stanley et al. (1994) and Hauk (1997) applied

\footnotetext{
${ }^{4}$ Interestingly, the marriage metaphor has also often been used to analyze issues in relations between firms (Nooteboom 1999b, appendix 4.1).
} 
Gale and Shapley's (1962) model in studies of the prisoner's dilemma, Tesfatsion $(1997,2001)$ has studied trade networks and labor markets, and Sherstyuk (1998) examines production coalitions between differentially skilled agents. Hauk (1997) mentions matching in the context of search - gathering of information to be used as an input for the matching; issues of information gathering and adaptive search for trading partners are also addressed in the context of industrial buying of fish on the Marseille fish market by Weisbuch et al. (forthcoming) and by Kirman and Vriend (2001). This is precisely the context in which a matching model was used in the current study; the way this was done is described in the following chapter. 


\section{Chapter 2}

\section{An Agent-based Approach}

This chapter presents our approach to studying problems of economic organization. Next to the discussion on substantive extensions to TCE in Section 1.2, this entails a second deviation from the transaction cost economics approach. In short, we take issue with the focus - in economics in general and in transaction costs economics in particular-on optimal outcomes. This focus and our objections against it are discussed in the next section. A more appropriate way of studying economic organization is presented in Section 2.2.

\section{$2.1 \quad$ Optimization}

One of the pillars on which TCE's analysis rests is the assumption that people are boundedly rational (see Section 1.1.1). If this is not assumed, the argument falls apart because complete comprehensive contracting is then feasible. With the assumption in place, TCE's analysis is aimed at finding the most appropriate organizational form for each possible type of transaction, in the sense of being 'aligned' with the attributes of that transaction-as discussed in Section 1.1.3.

However, the theory then goes on to hypothesize that organizational structures are aligned with the attributes of transactions. TCE therefore, suggests a higher level of rationality. On the one hand, people are 
assumed to be boundedly rational, but on the other hand, they are hypothesized to behave they way they would if they were rationally able to design the governance structures that are most appropriate given that they are boundedly rational. In other words, boundedly rational people are hypothesized to use precisely those governance forms for organizing transactions that they would use if they were unboundedly rational in choosing or designing them.

\subsubsection{Economic Natural Selection}

When confronted with this contradiction, (transaction cost) economists will usually admit that people are indeed not fully rational, but they will go on to suggest that people will behave like they would if they were (Alchian 1950, Enke 1951, Friedman 1953). Full rationality implies the ability to determine what-i.c. which organizational form - is optimal, given the circumstances (of bounded rationality, for example). The argument is that since suboptimal behavior and suboptimal organizational forms do not survive in the selection process of markets, they will not be found in empirical research. Presumably, this is why it is allowed to hypothesize outcomes in which transactions are perfectly aligned with organizational forms, while those responsible for the alignment are at the same time assumed to be largely unable to perform the alignment.

The reason for using this argument is that it allows economists to use mathematics and other formal methods for modeling problems in economics and solving them for optimal equilibrium outcomes. Another reason is that, looking at it this way, economists do not have to explain why economic activity is organized the way it is and how it has come to be organized that way rather than some other way. As mentioned in the introduction, it is irrelevant whether or not people are able to determine what is best for them; what matters is that economists are able to do that.

Apparently, this is preferred over taking the assumption of bounded rationality all the way, which effectively means allowing for an infinite array of outcomes consistent with more or less rational behavior, ranging from full rationality to full stupidity, so to speak. This would mean 
that models would be much more complex and difficult to analyze and that hypotheses would be much less straightforward to derive from those models. This is obviously a much more difficult task but, because of the seriousness of the objections discussed below, it is the one that was undertaken in the research described in this thesis - not that it was carried out completely, by the way. Only a small step was taken towards more realistic models; the decision-making situation is a very simple one. The main contributions to a more realistic study of economic organization are that (1) individual, boundedly rational agents are studied in each other's context, in which (2) they adaptively learn to make their own decisions while (3) influencing the consequences of each other's decisions.

\subsubsection{Objections against Optimization}

The evolutionary argument is used by economists to justify their search for optimal outcomes, by stating that suboptimal behavior is not relevant because it will not survive the selection process on markets. The economic natural selection argument is flawed on several accounts. Our objections against it are divided in those against the presumed effectiveness of the evolutionary selection process on the one hand, and against the appropriateness of the evolutionary model on the other hand.

\section{Objections within the Evolutionary Model}

First of all, the economic natural selection argument depends on the effectivess of markets in terms of weeding out suboptimal behavior. There are several reasons why this effectiveness may not be as high as it needs to be. If the argument is that it is only the best behavior that survives in a population, then the first and obvious objection is that economic natural selection does not yield the best conceivable (as resulting from a rational analysis), but merely the best present in the population (Winter 1964). Which behavior survives depends on the behaviors present in the population to begin with, and not on the analysis. The implication is that the population of agents itself should be part of the analysis.

A related point is that if the optimal behavior is not present in the 
population to begin with, it should be able to enter the population. Entry barriers may prevent this and thus protect incumbents and not put the pressure on them that forces them to behave in an optimal manner. Zero profits and price that equals marginal costs are only equilibrium outcomes under free and costless entry, while positive profits are often observed. Entry, however, is only the first phase of the general process in which optimal behavior enters the population and then spreads through it.

In the second phase, even if the optimum is present in the population to begin with or is able to enter the population, a mechanism has to be at work to transfer this optimal behavior from one agent in the population to the next. In biological evolution, the process of reproduction performs this task, but do organizations reproduce? It may be argued that an organization's genetic material is transferred to the organization's descendants in the form of organizational memory. Descendants are then the same organization at later moments in time. It is, however, hard to imagine how it could be transferred to other organizations, which it needs to if it is ever going to spread throughout the population, which, in turn, it needs to do if hypotheses based on rational analyses are ever to be confirmed. Especially tacit organizational knowledge is hard to transfer, because it has to be made explicit first, or be transferred in imitation which requires physical proximity. Why would organizations do that and transfer the knowledge that makes them successful to competing firms? Besides, if there is some imitative process at work, then what may be observed and imitated is behavior, and not necessarily the underlying knowledge and rules derived from it that make organizations successful.

Another reason why suboptimal behavior may survive, is that it is often not in direct competition with organizations behaving in a superior manner. Not all billiards players always win; they are still able to make a living if they do not always encounter stronger players. Different cultures exist in different parts of the world, where different ways of doing business exist (de Jong 1999). Because these groups are separated from each other geologically or otherwise, their differences can remain. Globalization and the internet, however, make competition more international, which puts pressure on some regions as different ways of doing business may invade them. Evolutionary game theory deals with these issues; see (Nooteboom 
1997) for an analysis of whether, in these kinds of models, opportunism will ever go away.

What these objections mean for transaction cost economics is that its analysis may not be helpful in designing hypotheses about economic organization. For example, Williamson (1985, p. 64-65) states that "[o]ne of the implications of opportunism is that 'ideal' cooperative modes of economic organization, by which I mean those where trust and good intentions are generously imputed to the membership, are very fragile. Such organizations are easily invaded and exploited by agents who do not possess those qualities", which clearly indicates his thinking in terms of an evolutionary model. As a consequence, such 'high-minded' organizational forms are immediatedly rendered nonviable. However, if this hypothesis is based on an evolutionary argument, then, as suggested by Koopmans (1957) long ago, its validity should be tested by modeling the evolutionary process explicitly. ${ }^{1}$ What Koopmans probably did not have in mind, but what is possible today, is to model the evolutionary process explicitly by simulating it on a computer, using a so-called genetic algorithm (see Appendix A, and see (Holland 1975) for the original publication and (Goldberg 1989) for a good general introduction). Miller (1996) did just that and found that an evolutionary process does lead to a high level of cooperation and trust in the population, which supports the view that the evolutionary metaphor does not support TCE's hypotheses.

In Section 2.2, an alternative approach is suggested for coming up with hypotheses about economic organization. This approach does not only use additional theoretical insights besides TCE, as discussed in Section 1.2 , but it is also not based on an evolutionary metaphor. In the current section, it has been argued that the evolutionary metaphor does

\footnotetext{
${ }^{1}$ See Blume and Easley (1998, p. 23), who "view [their] analysis as showing that Koopmans' cautionary remarks about the use of natural selection as the basis for profit maximization are correct. We show that it is simply not appropriate to argue for profit maximization on the basis of natural selection and then replace natural selection by profit maximization in either static or dynamic equilibrium analysis. It may be that profit maximizing behavior is a useful hypothesis, but the usefulness of natural selection as a defense of profit maximization is very limited".
} 
not support hypotheses consistent with rational optimization. It would be possible to use a genetic algorithm and derive other hypotheses from the evolutionary approach, but that is not what is attempted here, because the evolutionary approach itself is considered inappropriate. This is discussed in the next section.

\section{Objections against the Evolutionary Model}

I have raised these objections earlier (Klos 1997, Klos 1999), in relation to Miller's (1996) experiments mentioned earlier. They will be discussed here again, to guide the discussion at hand. Miller used a genetic algorithm to evolve a population of strategies for playing the repeated prisoner's dilemma, which is also an often-used model of inter-firm relations (see, e.g., Axelrod 1984, Hill 1990, Parkhe 1993). The prisoner's dilemma (PD) is a game that models the conflict between individual and collective interest. Two players both have to choose between cooperating or defecting (acting opportunistically), without knowing the other player's choice. Both players then receive a payoff that depends on both players' choices. Table 2.1 shows these payoffs, where $T$ stands for the tempta-

\begin{tabular}{cccc} 
& & \multicolumn{2}{c}{ Player II } \\
& & $\mathrm{C}$ & $\mathrm{D}$ \\
Player I & $\mathrm{C}$ & $(R, R)$ & $(S, T)$ \\
& $\mathrm{D}$ & $(T, S)$ & $(P, P)$
\end{tabular}

Table 2.1: Prisoner's Dilemma if $T>R>P>S$ and $2 R>T+S$ (for the Repeated PD).

tion to defect when the other player cooperates, $R$ stands for the reward a player receives when he cooperates when the other player also cooperates, $P$ stands for the punishment both players receive when they both defect and $S$ stands for the sucker's payoff for the player who cooperates when the other player defects.

The payoffs show that each player is better off by defecting irrespective of whether the other player cooperates (because $T>R$ ) or defects 
(because $P>S$ ). If the game is repeated, this grim perspective disappears because the possibility then opens up to make game-play reactive to previous moves, allowing players to punish defection and reward cooperation in the previous move, for example. This is only the case when the game is repeated indefinitively, however, because if the game has a known number of repetitions, backward induction makes defection the optimal choice in each round. Both players then know that the other player will defect in the last round, so they will both defect in the last round. This makes defection in the second-to-last round the rational choice as well, and so on until the very first round. This backward induction argument does not work if the game has an unknown or infinite number of rounds.

Miller (1996) used a population of 30 strategies and measured each strategy's fitness per generation as the average payoff per move (APM) across 150-round repeated PD's against the 30 strategies in the population (including itself). After this round-robin tournament, the 30 strategies were ranked by decreasing fitness. Miller used an elitist scheme in which the top 20 strategies proceeded to the next generation unchanged and 10 new strategies were created in each generation, using 2-point crossover conditional upon a $60 \%$ crossover-probability and bitwise mutation on the offspring conditional upon a $0.5 \%$ mutation probability. This means that 5 consecutive times, 2 strategies were selected from the entire previous population and, conditional upon a $60 \%$ probability, crossed with each other at two loci, after which each bit in each of the two resulting offspring was subjected to a $0.5 \%$ probability of being flipped (from 0 to 1 or vice versa).

Miller's (1996) experiments were replicated in (Klos 1999), ${ }^{2}$ and are presented in Figure 2.1. This figure shows the proportion of different types of outcomes averaged over the 150 rounds of the game and over all the games in the whole population in each generation and, in addition, over 40 runs of the experiment. It shows that, under selective pressure, it is in fact not the "ideal' cooperative modes" that are "easily invaded and exploited by agents who do not possess those qualities" (Williamson

\footnotetext{
${ }^{2}$ Because Miller's (1996) experiments were compared to my own experiments in which I used 36 agents, I replicated Miller's experiments with 36 strategies as well, with the same relative size of the elite.
} 


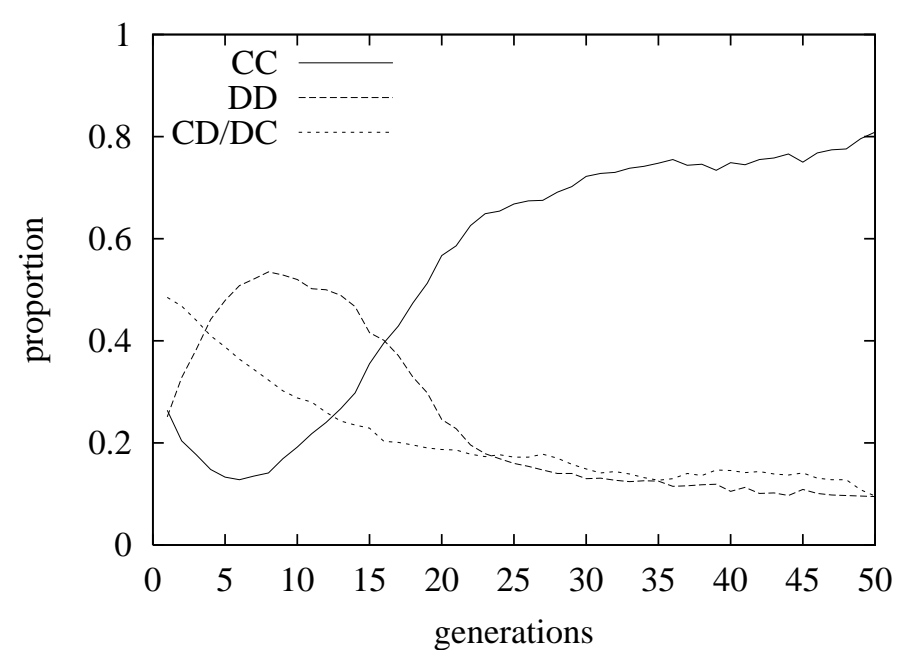

Figure 2.1: Outcomes in Miller's (1996) experiment.

1985, p. 64-65). Rather, those cooperative modes are the ones that survive in the long run. The (interesting) implications of these results for transaction cost economics are not derived here, but the focus is rather on the criticism I have on the evolutionary approach itself (cf. Klos 1999).

The main objection is that a genetic algorithm is essentially an instrument of optimization. Even though it is not guaranteed to find an optimum, it is the next best thing to optimizing when that is not possible analytically because of the complexity of a model. To this end, evolution as modeled in a GA and implemented, for example, by Miller, operates at the population level. Candidate solutions are usually represented as strings, often binary. These can be interpreted as points in a multidimensional search space. Miller (1996), for example, represented RPD strategies as Moore machines - a kind of finite state machine (FSM) which he coded as strings of bits. Figure 2.2 shows the famous strategy 'tit for tat' as a finite state machine. This strategy was invented by Anatol Rapoport and made famous in Axelrod's (1984) tournaments. It cooperates in the first round of the game and then mirrors the opponen- 


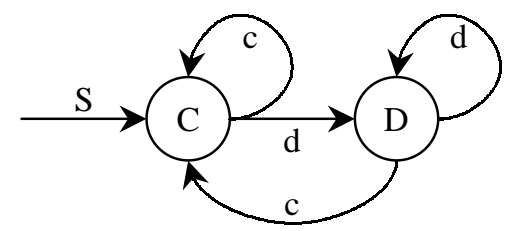

Figure 2.2: Tit-for-tat as a Moore machine.

t's previous move in subsequent rounds. In general, a Moore machine consists of (1) a set of internal states (the circles in Figure 2.2), one of which is designated to be (2) the starting state (labeled 'S'), (3) an output function that maps each internal state onto an output, i.c. a choice between the alternative actions $\mathrm{C}$ and $\mathrm{D}$ (the uppercase characters inside the circles) and (4) a transition function that maps each internal state onto a next state (designated by arrows in Figure 2.2) for each of the opponent's possible actions (the lowercase arrow labels). Miller (1996) used machines with a maximum of 16 internal states, which he coded as strings of 148 bits. $^{3}$

Each possible strategy can be seen as a point in a 148-dimensional space. Each strategy is a solution to the problem of being successful in a repeated prisoner's dilemma. This success, of course, depends on the strategy played against, so Miller let the strategies co-evolve, which means that their fitness and therefore chances of survival are determined in part by the other strategies in the population. This was achieved by calculating fitness as the average payoff per move in games against all strategies in the population in the current generation. Fitnesses can be thought of as values on the $149^{t h}$ dimension, as a fitness-landscape on the original search space. ${ }^{4}$ The objective is to find the 148 -dimensionsal

\footnotetext{
${ }^{3}$ Because 4 bits can represent 16 different numbers, it takes 4 bits to designate the starting state. For each of the 16 states, it takes 1 bit to specify the value of the output function ( 0 for $\mathrm{C}$ and 1 for $\mathrm{D}$ ) and 4 bits to specify each of the two values of the transition function (one for the opponent's cooperation and one for his defection). This means it takes a total of $4+9 \cdot 16=148$ bits.

${ }^{4} \mathrm{It}$ is easier to visualize the fitness-landscape as the third dimension on a 2dimensional search space. The objective is then to find the highest peak in the fitness-landscape. The point in the 2-dimensional search space corresponding to that
} 
point with the highest fitness. It is obviously a very hard problem to determine what the best strategy is, and there probably is not even a best strategy for all circumstances, i.e. against all possible opponents. A genetic algorithm can very well be used for these kinds of problems that can not be solved analytically. Instead of trying to optimize an unknown finess-function, or calculate the fitness of all possible points in the space, in each of a sequence of generations it samples a limited number of solutions in the search space in parallel, and uses information about the performance of those different solutions to direct search towards promising regions of the search space in the next generation, when it explores those promising regions further.

The properties that make a GA successful, however, are the very same properties that make it inappropriate for modelling individual agents' adaptive behavior. Most importantly, notwithstanding the effects of communication and reputation, individuals do not have access to information about the performance of all the strategies they did not use themselves; they only have access to their own experience for guiding their search, and maybe those of a limited number of other agents, like the ones they interact with directly. These objections can be illustrated by considering what a GA-model means when viewed from the perspective of an individual in the population. Some very strong assumptions are made - all too often only unconsciously. ${ }^{5}$ These assumptions follow from modellingdecisions made to let the GA function efficiently and effectively, but they are not realistic from the individual agent's perspective. ${ }^{6}$

peak is the solution to the problem.

${ }^{5}$ See also Vriend's (1998) experiments, who also confronted the results from a genetic algorithm (which implements what he calls 'social learning') with individual agents' 'individual learning'. His conclusions is that the "lesson to draw here is that the computational modeling choice between individual and social learning algorithms should be made more carefully, since there may be significant implications for the outcomes generated" (1998, p. 11, emphasis added).

${ }^{6}$ Whether or not this is a problem, depends on what the GA is used for, of course. When it is used with the intention to solve a hard problem, then it does not matter that these assumptions are implausible from the perspective of the members of the population - which it does when the GA is used as a representation of individual adaptive learning. One could, out of curiosity for example, use a GA with the intention 
1. First of all, all the agents in the population interact with all other agents in the population, while people typically only interact with a limited number of others, namely those who are physically, culturally, emotionally, or otherwise close to them. This was done because it directs the GA's search towards strategies that perform well in general, rather than just against a small number of fixed strategies (as in Axelrod's (1987) experiments, for example), which the population would then specialize to.

2. Secondly, and more importantly, the decision to change a strategy is not taken by the agent using the strategy but by the parameters that regulate the GA's operation. For example, the 20 top performers are forced to keep their strategy, and the 10 worst performers are forced to change their strategy. Even apart from the specifics of this elitist scheme, the decision to change a strategy is simply not taken by the agent himself, while, reasonably, it should be. Instead, it is taken on the basis of a comparison of the agent's performance and all other agents' performance, whereas, in relation to the first point, comparison with only those somehow 'close' to the agent would be more appropriate. This mirrors the fact that the GA is not about agents but about strategies; the GA searches for optimal strategies, irrespective of what agents using strategies would do.

3. Thirdly, when comparing an agent's performance to other agents' performance, those other agents' experiences in all their games are taken into account, most of which the agent did not partake in himself. Experiences are assumed to be transferable from one agent to the next. This is an important mechanism that makes the GA successful, but from the perspective of the individual agent, it means

to replace or supplement TCE's rational analysis in a model that can not be solved analytically, but then it should not be claimed that the outcome of the GA is a good hypothesis of what people actually do in situations characterized by that model. It could be used "as a benchmark against which to assess the performance of more realistically modelled social learning mechanisms" (Tesfatsion 2001, p. ??). 
that he not only has access to the experiences of all other agents in the population, but also that those are relevant to his own situation.

4. Finally, when creating new strategies, old strategies from the whole population are used, while, in relation to the first and second points above, any imitative process would more likely be based on those close to the agent. Moreover, the agent would never even be able to perceive other agents' strategies, but only their behavior in mutual games, as generated by their underlying strategies. Because the GA operates on strategies, this is not a problem; at the level of the population of 'solutions', all strategies are visible and can be manipulated in the search for better ones.

In (Klos 1999), these considerations led me to design a different setup for modeling agents' adaptive social behavior, in which all agents are located in the cells of a grid, interact only with their immediate neighbors on the grid and themselves decide on changing their strategy on the basis of their own comparison of their own performance with only their immediate neighbors' performance.

Others have also noticed some of these considerations. In another application of a GA-derived from a follow-up (Stanley et al. 1994) on an early version of Miller's (1996) experiments (Miller 1989)-Tesfatsion (2001, p. ??), for example, notices that

"[a]n important caution is in order here, however. The information that work suppliers and employers are currently permitted to have access to in the evolution step is substantial: namely, complete knowledge of the collection of strategies used by agents of their own type in the previous trade cycle loop, ranked by fitness. The evolution step is thus more appropriately interpreted as an iterative stochastic search algorithm for determining possible strategy configuration attractors than as a social learning mechanism per se. The resulting welfare outcomes will be used in subsequent work as a benchmark against which to assess the performance of more realistically modelled social learning mechanisms." 
The point is that we are not interested in 'strategy configuration attractors', but in 'more realistically modelled social learning mechanisms'. On the one hand, what Tesfatsion (2001) and other economists using genetic algorithms are doing, is going down to the level of individual agents. I agree that we should do this, even though it makes models much more complex, as discussed in Section 2.1.1. But on the other hand, what they use genetic algorithms for is to look for equilibria, 'strategy configuration attractors', and optimal outcomes in those more complex models once again, because their models can not be solved analytically. This is precisely what I have argued earlier that we should not be doing, which is why, in the next section, I propose a form of learning at the level of the individual, analogous to the model in (Klos 1999).

\section{$2.2 \quad$ Agent-based Computational Economics}

The approach taken in this thesis operates at the level of individual, boundedly rational, adaptive agents. They may still search a space of solutions like the 148-dimensional space Miller (1996) created, but they do so by adapting on the basis of their own personal experiences. A number of such agents are allowed to interact with each other and adapt their behavior on the basis of their experiences in those interactions. The behavior that emerges from these interactions may not be optimal at the population level, but it will be at the level of the agent, at least to the extent that the agent's bounded rationality lets him establish that.

This approach falls under the heading of 'Agent-based Computational Economics' (ACE), "the computational study of economies modelled as evolving systems of autonomous interacting agents" (ACE-website): ${ }^{7}$

"A central concern of ACE researchers is to understand the apparently spontaneous formation of global regularities in economic processes, such as the unplanned coordination of

\footnotetext{
${ }^{7}$ http://www.econ.iastate.edu/tesfatsi/ace.htm
} 
trade in decentralized market economies that economists associate with Adam Smith's invisible hand. The challenge is to explain how these global regularities arise from the bottom up, through the repeated local interactions of autonomous agents channeled through socio-economic institutions, rather than from fictitious top-down coordination mechanisms such as imposed market clearing constraints or an assumption of single representative agents."

This approach is used more and more often to study problems in economics-problems that can not be solved analytically, because the search space is too large or because the function to be optimized is unknown. ${ }^{8}$ The essence of this approach is to model individual agents explicitly and to focus on the process in which they interact with each other and adapt their behavior on the basis of their experiences in those interactions. Economic phenomena can then be studied as the outcomes that emerge from actual (simulated) interactions between individual, boundedly rational, adaptive agents. Whether an interaction takes place between any two given agents is left for them to decide. What the agents subsequently do in that interaction is their own - possibly sub-optimaldecision, that they make on the basis of their locally available, incomplete information and as a result of their own (cognitively-limited) processing of that information.

These processes and the outcomes that emerge from them are considered more interesting and useful than equilibria deduced from models employing representative agents, auctioneers or anonymous, random matching, etc., models that require very limiting assumptions in order for formal derivations to go through. As Schelling (1978, p. 26) puts it, "[t]here is nothing particularly attractive about an equilibrium. An

\footnotetext{
${ }^{8}$ Examples include the problem of being successful in the repeated prisoner's dilemma (Klos 1999, Miller 1996, Stanley et al. 1994), in social dilemmas (Glance and Huberman 1994) as well as on final-goods markets (Albin and Foley 1992, Vriend 1995), stock markets (Arthur et al. 1997), industrial markets (Péli and Nooteboom 1997), whole-sale markets (Kirman and Vriend 2001, Weisbuch et al. forthcoming), labor markets (Tesfatsion 2001), and spatial political models (Kollman et al. 1992, Miller and Stadler 1998).
} 
equilibrium is simply a result. It is what is there after something has settled down, if something ever does settle down. The idea of equilibrium is an acknowledgement that there are adjustment processes". Still, even if it is considered interesting to know what the equilibrium in an economic system is, then there are still several reasons for taking up alternative lines of inquiry, such as the study of out-of-equilibrium adjustment processes - for example by means of computer simulations, as in this thesis.

First of all, an equilibrium may be very hard or even impossible to find, or 'compute' (cf. the work at the UCLA Center for Computable Economics $\left.{ }^{9}\right)$. All that is left, then, is to study out-of-equilibrium dynamics. Secondly, there may be very many equilibria so that investigating how the system evolves may provide information about which of those equilibria are more probable, likely or otherwise interesting than others. This is what evolutionary game theory is about. Thirdly, and relatedly, as stated by David (1985), ${ }^{10}$ "it is sometimes not possible to uncover the logic (or illogic) of the world around us except by understanding how it got that way". Fourthly, it is possible to study equilibria as the result of and in their relation to out-of-equilibrium dynamics. Much of the focus on equilibrium in economics has been forced onto economists by the difficulty of studying anything else - that is, by the absence of appropriate tools for studying anything other than equilibrium, like the more interesting adjustment processes mentioned by Schelling (1978). Holland (1992) describes how it has recently become possible to study complex adaptive systems using computer simulations and states that, now that it's possible, "[i]t is the process of becoming rather than the never-reached end points that we must study if we are to gain insight" (1992, p. 19). Finally, if one wants to intervene in a process with the intention of reaching a desired outcome, one needs to understand how the process that leads to the outcome, does so, and what the effects of measures taken now, are on the outcome obtained later (Nooteboom 2000).

\footnotetext{
${ }^{9}$ http: //cce.sscnet.ucla.edu/

${ }^{10}$ This often-cited paper provides the main example of 'path dependence' (the lockin to the QWERTY typewriter configuration), on which much work by Brian Arthur and others at the Santa Fe Institute (http://www.santafe.edu) is based.
} 
One needs positive knowledge about the way the system develops, which might be revealed by computer simulations - or by longitudinal empirical studies, but those are often not feasible in studies of managament and organization. Besides, in empirical research it is impossible to observe the effects of measures not taken, while computer simulations can always be re-run under different settings; these are the traditional advantages of computer simulations. Epstein and Axtell (1996) refer to these artificial societies using the term 'CompuTerrarium', in which social structures can be grown 'in silico'.

\subsubsection{Complex Adaptive Systems}

ACE is the specialization to economics of the basic Complex Adaptive Systems (CAS) paradigm. There are two important aspects of CAS.

\section{Complex Systems ...}

A complex adaptive system (CAS) "is a complex system containing adaptive agents, networked so that the environment of each adaptive agent includes other agents in the system" (Holland and Miller 1991, p. 365). This paradigm seems to fit very well the case of transaction cost economics, where, according to a recent statement by the founding father of transaction cost reasoning, Coase (1995, p. 245)

"[t]he analysis cannot be confined to what happens within a single firm. The costs of coordination within a firm and the level of transaction costs that it faces are affected by its ability to purchase inputs from other firms, and their ability to supply these inputs depends in part on their costs of coordination and the level of transaction costs that they face which are similarly affected by what these are in still other firms. What we are dealing with is a complex interrelated structure."

Holland (1992) and Holland and Miller (1991) suggest to study economic systems as complex adaptive systems. The CAS approach appears 
to be ideally suited to deal with Coase's (1995) observation, which is what is attempted in the research described in this thesis.

\section{... and Adaptive Agents}

An agent in a Complex Adaptive System (CAS) is adaptive if "the actions of the agent in its environment can be assigned a value (performance, utility, payoff, fitness, or the like); and the agent behaves in such a way as to improve this value over time" (Holland and Miller 1991, p. 365; see also (Vriend 1995)). In the context of economic organization, this means that agents adaptively choose organizational forms in such a way that their performance, as dependent upon their choice of structural form for organizing transactions, improves over time.

The assumptions of bounded rationality and potential opportunism, combined with the condition of asset specificity are all three needed as conditions for the existence of firms, i.e. conditions under which the market looses (some or even all of) its advantage because of increasing transaction costs. Although necessary, these conditions are not necessarily sufficient for the existence of firms. TCE says that under these circumstances firms may exist, but it does not explain how they come into existence: it specifies the conditions under which firms have a comparative advantage over markets, but not what is required for this advantage to be translated into the actual emergence of firms. As in (Axtell 1999), this is an issue that is addressed in this thesis by means of agent-based computational modeling - it can not be done within TCE's conceptual framework. It can be done if one looks at individual agents and their micro-motives (Schelling 1978) and the way those change over time in response to the agents' experiences.

\subsubsection{Agent-based Computational Transaction Cost Economics}

In the research described in this thesis, the ACE methodology was applied to issues of economic organization. Economic organization is studied from the bottom up (cf. Epstein and Axtell 1996); the resulting distri- 
bution of economic activity across different organizational forms emerges from processes of interaction between these agents, as they adapt future decisions to past experiences. The system may or may not settle down and if it does, the resulting equilibrium may or may not be transaction cost economic.

Individual, boundedly rational economic agents are simulated in a computational model, along with the transaction they may organize between each other (cf. Albin and Foley's (1992), Vriend's (1995) and Weisbuch et al.'s (forthcoming) approach). As in Vriend's (1995, p. 205) model, "market interactions depend in a crucial way on local knowledge of the identity of some potential trading partners". The agents themselves decide whether they want to make or buy; the option to outsource, however, really just consists of a number of suppliers to outsource to. A market has to be 'made', before it can ever used as a governance form (Vriend 1995, Vriend 1996, Weisbuch et al. forthcoming). Rather than rely on standard, anonymous random matching devices, these decisions are also explicitly incorporated in the model. Agents are assumed to have differential preferences for different potential trading partners (Weisbuch et al. forthcoming). The actual agents and the actual transactions are incorporated in the model and the agents adaptively search suitable structural forms for organizing their transactions. 


\section{Chapter 3}

\section{The Simulation Model}

This chapter presents an agent-based computer simulation model to investigate issues of economic organization in the manner proposed in the previous chapter. As described in Section 2.2.2, this means creating a population of artificial adaptive agents and investigating the organizational regularities that emerge from the interactions they initiate between them and from which they receive the feedback they use to adapt their behavior. Section 3.1 describes the model at a global level. Subsequent sections will elaborate on different elements of the model, as described in Section 3.1.

\subsection{The Main Loop}

The model involves two types of agents that simulate firms. There are firms that sell products on a final-goods market. In order to produce this product, they need certain inputs or components. They can either produce the components themselves, or acquire them on an intermediategoods market by outsourcing component-production to specialized suppliers. We focus on this intermediate-goods market, and call the two types of firms buyers and suppliers.

Buyers need to decide on the form they use for organizing the transaction between the production and the assembly of components. We as- 
sume that they assemble their product themselves, and that they choose between in- and outsourcing component-production. As discussed in the previous chapter, we model their boundedly rational, adaptive decisionmaking process explicitly. This decision-making is boundedly rational because the agents use only limited information and information-processing capacity when making decisions. Rather than perform exhaustive analyses, the agents use an internal model of their decision-making environment to estimate the consequences of different courses of action. On the basis of this assessment, they make a choice. The choices of all the agents together yield an outcome that each of them uses for adapting his internal model so that in the future it will generate better predictions. Computer simulations of this co-adaptive process are used to find out where it leads under different circumstances: which courses of action do the agents learn, while the other agents are also learning? Does the process lead to transaction cost economic outcomes?

The agents develop differential preferences for other agents. Each supplier has preferences for different buyers and each buyer has preferences for different suppliers, including himself - a buyer supplies to himself when he makes rather than buys, so he also has a certain preference for himself as a supplier. If there is no supplier for whom a buyer has a higher preference than he has for himself, then he makes his own components. If there are one or more suppliers for whom the buyer has a higher preference than he has for himself, he will try to set up or continue a relation with one of those suppliers. The buyer will outsource to that supplier if he succeeds and make his own components if he does not. The way the agents establish their preferences is described in more detail in Section 3.2.

Once established, all agents' preferences are used to assign agents to each other. This assignment is done by executing a so-called 'matching algorithm', which is discussed in Section 3.3. When the algorithm has finished, each buyer is either matched to a supplier or to himself, as illustrated in Figure 3.1. Suppliers that are matched to one or more buyers (suppliers 1 and 3 in Figure 3.1) produce for and deliver to those buyers, while buyers that are not matched to a supplier (buyer 2 in Figure 3.1) produce for themselves. Finally, all buyers sell their product on the 


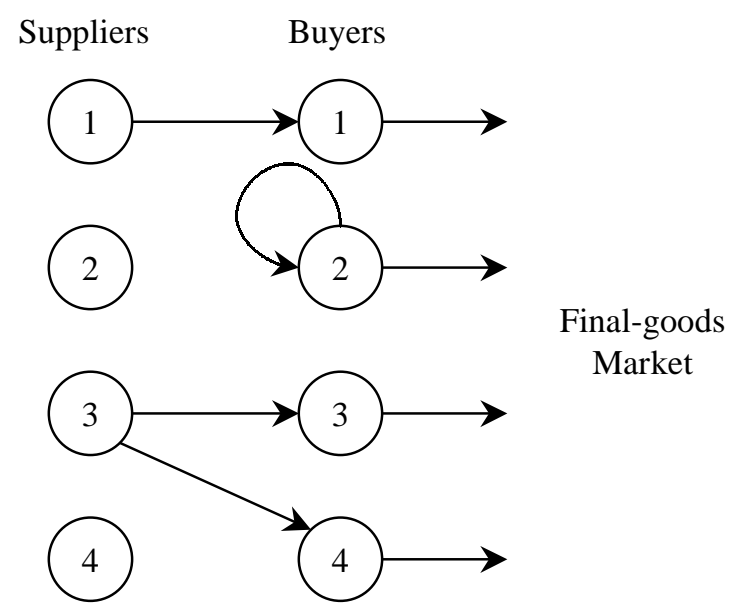

Figure 3.1: Buyers are assigned to suppliers or to themselves.

final-goods market. This gives them a profit, which they share with their supplier, if they have one. All agents then use the profit they obtained for updating their internal model, which may cause them to change their preferences. In general, the updating leads to the construction of internal models that cause the agents to make decisions that generate high profits, and to avoid decisions that lead to low profits. This process of adaptation is discussed in Section 3.4. The final section (3.5) summarizes the model by means of a flowchart of the simulation; details about the simulation program can be found in Appendix B.

\subsection{Preferences: Profit, Trust and Loyalty}

The agents have preferences for each other that are based on 'scores' they assign to others: the higher the score an agent assigns to another agent, the greater the agent's preference for being matched to that other agent. Such a score is a function of expected profit, in the sense of the product of potential profit and the probability of realizing that potential. Since potential profit is only realized when the other agent does not behave opportunistically, we call an agent's subjective assessment of this proba- 
bility his trust in the other agent. Furthermore, when calculating scores, the agents can assign differential weights to potential profit vs. trust. In addition, an agent can be loyal to his current partner by increasing that current partner's score as compared to the scores of alternatives. To the extent that an agent is loyal, he does not prefer alternative partners even though, absent loyalty, he assigns strictly higher scores to them.

This interpretation of agent $i$ 's trust in $j$ as $i$ 's subjective probability that $j$ will not behave opportunistically, is in line with the literature on trust (Deutsch 1973, Gambetta 1988) as well as with TCE, as explained in Section 1.2.1. Note that we are not claiming that trust plays a role, but there are strong indications from the literature on buyersupplier relations that it does. We allow agents to take trust into account (i.e. to assign a positive weight to it relative to potential profit) in calculating scores, and then simulate their adaptive decision-making process to find out whether or not they do. Similarly, we are not claiming that agents should be loyal, but we allow them to be, and then investigate whether or not they learn to be. Also note that our definition of trust means that trust in intentions rather than in competence is implied here, as the complement of opportunistic behavior (see Section 1.2.1 and Nooteboom 1999b). We are interested only in trustworthiness as the absence of opportunistic behavior, just like TCE is. In our model, it is therefore never possible for agents to be unable to do what is expected of them; they can only be unwilling to do so.

\subsubsection{Scores and Loyalty}

Each agent $i$ assigns a score to all the agents $j$ he can possibly be matched to. For a supplier this means assigning scores to all buyers and for a buyer it means assigning scores to all suppliers and to himself. The score that an agent $i$ assigns to another agent $j$ expresses the profit agent $i$ expects to make in a relation with agent $j$. This expected profit is equal to the potential profit inherent in the relation between agents $i$ and $j$, multiplied with agent $i$ 's subjective probability that agent $j$ will not behave opportunistically but will let agent $i$ realize this potential profit - this subjective probability is agent $i$ 's trust in agent $j$. 
We let agents calculate scores as the product of potential profit and trust, because we want the two factors to interact: if either the potential profit inherent in a relation between agents $i$ and $j$, or $i$ 's trust in $j$ is zero, then the score that $i$ assigns to $j$ has to be zero as well-there would be no reason for $i$ to interact with $j$ in either case. ${ }^{1}$ In addition, as explained above, we are not claiming that trust should be important, but we want to investigate whether the agents learn to consider it important. Therefore, we allow agents to attach different weights to profitability versus trust and let them adapt the weights they use. The simplest functional form that satisfies these two criteria is the Cobb-Douglas functional form, so we specify:

$$
s_{i}^{j}=\left(p_{i}^{j}\right)^{\alpha_{i}} \cdot\left(t_{i}^{j}\right)^{1-\alpha_{i}},
$$

where

$$
\begin{aligned}
s_{i}^{j}= & \text { the score that } i \text { assigns to } j, \\
p_{i}^{j}= & \text { the profit } i \text { can make as a result of coordinating the } \\
& \text { transaction with } j, \\
t_{i}^{j}= & i \text { 's trust in } j, \\
\alpha_{i} \in[0,1]= & \text { the weight that } i \text { attaches to } p_{i}^{j} \text { relative to } t_{i}^{j}, \text { i.e. the } \\
& \text { 'profit-elasticity' of the scores that } i \text { assigns. }
\end{aligned}
$$

This specification implies that score is equal to profitability if $\alpha_{i}=1$ and equal to trust if $\alpha_{i}=0$. Note that agent $i$ 's trust has subscript $j$, while $\alpha$ only has subscript $i$ : while agent $i$ may trust other agents in different degrees, he uses the same value for $\alpha$ to calculate all those other agents' scores. Agent $i$ 's experiences in one relation carry over to the weight he assigns to profitability versus trust in other relations.

As explained above, the agent not only assigns differential weights to another agent's profitability versus his trust in that other agent, but he may also be loyal to his current partner, if he has one. This is implemented as a variable $\tau \in[0,0.5]$ that is added to the current partner's score. Even when an agent assigns strictly higher scores to other agents, he will not have a higher preference for those other agents than for his

\footnotetext{
${ }^{1}$ This also expresses the fact that it is not claimed here that trust has any value for its own sake, when there is no profit to be made.
} 
current partner, as long as the difference between the scores he assigns to those other agents relative to his current partner does not exceed the threshold $\tau$. Just like in the case of $\alpha$, we are not claiming that the agent should be loyal and use a high value for $\tau$. We are merely allowing agents to use different values for $\tau$ and we will investigate which values the agents learn to use.

The next two sections (3.2.2 and 3.2.3, respectively) describe how profitability and trust are determined.

\subsubsection{Profitability}

Buyers and suppliers have different capabilities and bring different ways of generating profit to a relation. Essentially, a buyer may increase returns, while a supplier may decrease costs; both contributions have a positive influence on the profit that can be made in a relation between them. A buyer's potential to generate profits in a relation is a function of his position on the final market - where he is a seller-as expressed in product differentiation. A supplier's potential to generate profits for a buyer is determined by his efficiency in producing for the buyer. The agents involved in a transaction are assumed to share the profit they make between them.

\section{Product Differentiation}

Differentiated products yield a higher profit than standardized products. With standardized products one can only compete on price and under free and costless entry to the market, this drives price down to marginal cost, as proposed in standard micro-economics. Differentiated products, on the other hand, allow for positive profits.

Products as well as consumers can be located as points in a multidimensional 'product characteristics space' (Lancaster 1966). The location of a product represents the bundle of characteristics that it offers and the location of a consumer represents that consumer's 'ideal product'. In geometrical terms, the distance between the two determines the cost that the consumer who buys the product has to incur in order 
to 'transport' the product to his own location. In psychological terms, when there is a distance between the product and the user, the user has to settle for 'less' than his ideal product and will be unwilling to pay as high a price for it as he would be willing to pay for his ideal product. In general, consumers will buy the product which has the lowest total of price plus cost of transportation to their own location, or in other words, "consumers (...) are prepared to pay more for variants that are better suited to their own tastes" (Anderson et al. 1992, p. 1).

Firms that sell differentiated products therefore have some degree of 'market power': they can raise the price for which they sell their product and thus make a profit, without losing all of their customers to competitors as with standardized products. In particular, they will retain those customers whose distance to the product is so small that the price increase over competitors is smaller than the extra transportation cost to the nearest competing product variant. This degree of market power will be expressed in a buyer-specific variable $d_{i} \in[0,1]$ that determines the returns to the buyer when he sells his products. Specifically,

$$
r_{i}=1+d_{i}
$$

where

$$
\begin{aligned}
& r_{i}=\text { the returns for buyer } i \text { from selling a product and } \\
& d_{i}=\text { the differentiation of buyer } i \text { 's products. }
\end{aligned}
$$

These returns increase with the differentiation of his product, i.e. with the extent to which his product corresponds to consumers' ideal products, relative to his competitors products.

\section{Efficiency and Asset Specificity}

Each buyer produces and sells one product per timestep, for which he needs one component. The production of this component, whether conducted by a specialized supplier or by the buyer himself, requires assets to be invested in. In principle, 1 unit of assets is required to produce 1 product, but increasing efficiency may decrease this amount. 
We will assume that only a specialized supplier can enjoy efficiencyadvantages, which is why this exposition on efficiency only applies to suppliers-buyers always produce with efficiency 0 . The assets that a supplier invests in are either 'specific' to the buyer for whom he produces or they are 'general-purpose'. Since "asset specificity is never valued by itself but only because demand is thereby increased in design or performance respects" (Williamson 1981a, p. 558), we will assume a relation between the degree in which the supplier's assets are specific to the buyer for whom he produces, and the differentiation of that buyer's product.

The rationale is that, if a buyer $i$ 's product is differentiated $\left(d_{i}>\right.$ $0)$, then, relative to consumers' tastes, $i$ 's product is different from his competitors' products. Assets invested in to produce $i$ 's product can then not easily be switched to the production of those competitors' (different) products. In other words, those assets are then specific to the production of $i$ 's product. On the other hand, if products are not differentiated but standardized, then assets invested in to produce the product for one buyer can easily be switched to producing products for other buyers. The simplest way to model this relation, is to assume that

$$
k_{j}^{i}=d_{i}
$$

where $k_{j}^{i}$ is the specificity of supplier $j$ 's assets to buyer $i$. The more differentiated a buyer's product is, the more specialized to that buyer are the assets that a supplier invests in to produce components for that buyer's product.

As shown in Figure 3.1, each buyer is either assigned to a supplier or to himself. A supplier, on the other hand, may supply to multiple buyers, which enables him to increase his volume of production and generate scale economies, but only in his use of general-purpose (non-specific) assets. The supplier's assets that are specific for the various buyers he produces for, can not be substituted for one another by definition, and can therefore also not be added together to generate scale-economies. Those specialized assets are subject to an experience effect, however. This means that, over time, the supplier gets more efficient in using buyer-specific assets for each specific buyer he produces for. 
These two efficiency-effects (scale and experience) are implemented as follows. For each of the buyers that a supplier $j$ produces for, he invests in 1 asset, which is divided in a part that is specific for the buyer, and a part that is not specific for this or any other one particular buyer. The proportion of the asset that is specific for buyer $i, k_{j}^{i}$, is $d_{i}$ (equation 3.3); the remainder is general purpose. The total of general purpose assets required is

$$
g_{j}=\sum_{i=1}^{I}\left(1-d_{i}\right) m_{j}^{i}
$$

where

$$
\begin{aligned}
g_{j}= & \text { general purpose assets required by supplier } j, \\
I= & \text { the total number of buyers in the simulation }(J \text { is the } \\
& \text { total number of suppliers }), \text { and } \\
m_{j}^{i}= & 1 \text { if supplier } j \text { produces for buyer } i \text { and } 0 \text { otherwise. }
\end{aligned}
$$

As described above, both specific and general purpose assets are subject to efficiency-effects. The supplier's accumulation of general purpose assets is subject to a scale-effect, and the supplier's continuous use of buyer-specific assets is subject to an experience-effect. Positive efficiency means that a supplier needs less than the total of 1 asset to produce the component for one buyer. Specifically, supplier $j$ requires only $k_{j}^{i}\left(1-e_{l, j}^{i}\right)$ instead of $k_{j}^{i}$ specific assets, where $e_{l, j}^{i}$ is supplier $j$ 's efficiency due to experience (or learning-by-doing) in producing for buyer $i$, and only $\left(1-k_{j}^{i}\right)\left(1-e_{s, j}\right)$ instead of $\left(1-k_{j}^{i}\right)$ general purpose assets, where $e_{s, j}$ is supplier $j$ 's efficiency due to scale. Supplier $j$ 's costs of producing the component required by buyer $i$ are therefore

$$
c_{j}^{i}=k_{j}^{i}\left(1-e_{l, j}^{i}\right)+\left(1-k_{j}^{i}\right)\left(1-e_{s, j}\right),
$$

where 
$c_{j}^{i}=$ supplier $j$ 's costs of producing a component for buyer $i$,

$k_{j}^{i}=$ specific assets required by supplier $j$ to produce for buyer $i$ (equation 3.3),

$e_{l, j}^{i}=$ supplier $j$ 's efficiency due to experience (the $l$ stands for learning) in using assets, specific for buyer $i$,

$g_{j}=$ general purpose assets required by supplier $j$ (equation 3.4),

$e_{s, j}=$ supplier $j$ 's scale-efficiency.

Both the scale- and the experience-effect are modeled using essentially the same function.

$$
y=\max \left[0,1-\frac{1}{f x+1-f}\right]
$$

where

- for the scale effect, $f$ takes the value of the parameter scaleFactor, $x=g_{j}$ (see equation 3.4) and $y=e_{s, j}$,

- for the experience effect, $f$ takes the value of the parameter called learnFactor, $x$ is the number of consecutive timesteps that supplier $j$ has supplied to buyer $i$, and $y=e_{l, j}^{i}$.

To illustrate, this function is represented graphically in Figure 3.2 for different values of $f$. The graph shows that a supplier can be more scaleefficient than a buyer producing for himself only if the scale at which the supplier produces is larger than the maximum scale at which a buyer might produce for himself: the graph is positive only for more than 1 general purpose assets. Furhermore, a supplier's buyer-specific learningefficiency is 0 in their first transaction, and only starts to increase if the number of transactions is larger than 1, which implements TCE's fundamental transformation, according to which (Williamson 1981b, p. 1548),

"[w] hat may have been (and commonly is) an effective largenumbers-bidding situation at the outset is sometimes transformed into a bilateral trading relation thereafter. This obtains if, despite the fact that large numbers of qualified bidders were prepared to enter competitive bids for the initial 


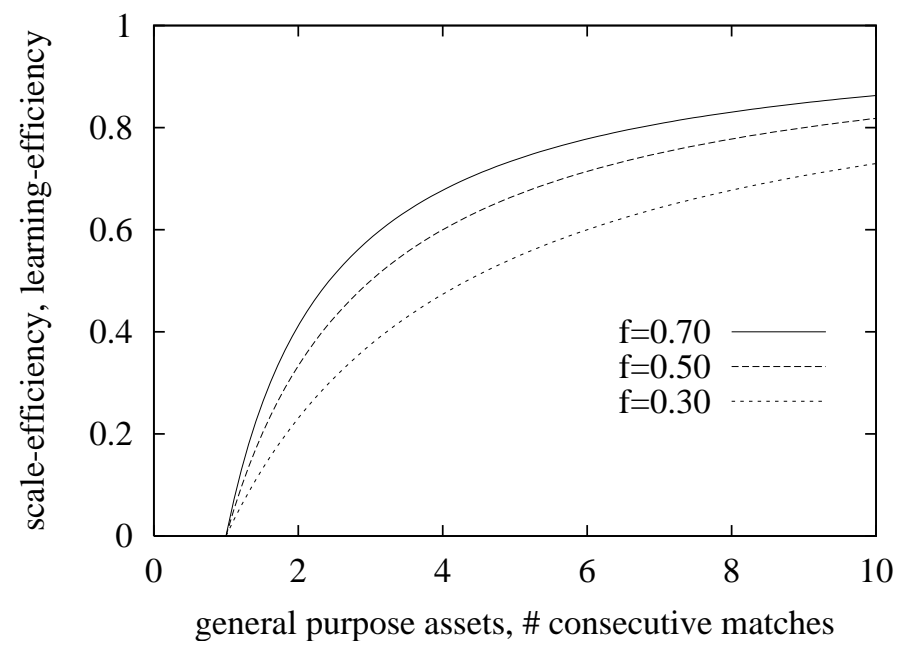

Figure 3.2: Efficiency due to scale and experience.

contract, the winning bidder realizes advantages over nonwinners at contract renewal intervals because nontrivial investments in durable specific assets are put in place (or otherwise accrue, say in a learning-by-doing fashion) during contract execution."

In the current model, the emphasis is put on the second option mentioned (between brackets). The first option was attempted in an earlier version of the model, but implementing it required too many assumptions about the depreciation of investments. Returning to this issue is one possibility for future work.

Above, we have assumed that a buyer is not able to increase his own efficiency in producing components. First of all, although a buyer can be his own supplier, he is not allowed to produce for and supply to other buyers. He can therefore never generate economies of scale. Furthermore, it is assumed that the experience effect that works for a supplier is related to synergy between the buyer's and the supplier's contribution to their transaction. This precludes the buyer from generating this effect when he produces for himself. 
To sum up, the profit that can potentially be made in a transaction between a buyer $i$ and a supplier $j$ is shared equally by the agents involved:

$$
p_{i}^{j}+p_{j}^{i}=\left(1+d_{i}\right)-\left(d_{i}\left(1-e_{l, j}^{i}\right)+\left(1-d_{i}\right)\left(1-e_{s, j}\right)\right) .
$$

The first part specifies returns (see equation 3.2) and the second part specifies costs (see equations 3.5 and 3.3).

\subsubsection{Trust and Opportunism}

In the model, opportunism means that an agent may break a 'relation', i.e. a sequence of timesteps in which that agent transacted with another agent, without taking that other agent's situation into account. An agent's trust in another agent is interpreted as that agent's subjective probability that the other agent will not behave opportunistically. Following Gulati (1995), we will assume that trust increases with the duration of a relation: as a relation lasts longer, one starts to take the partner's behavior for granted, and to assume the same behavior (i.e. commitment, rather than breaking the relation) for the future. In the model, this increase over time is implemented using a variation of equation 3.6. Additions are 'memory' and a base-level of trust. An agent $i$ 's trust in another agent $j$ depends on what that trust was at the start of their current relation and on the past duration of their current relation:

$$
t_{i}^{j}=t_{\text {init }, i}^{j}+\left(1-t_{\text {init }, i}^{j}\right)\left(1-\frac{1}{f x+1-f}\right)
$$

where

$$
\begin{aligned}
t_{i}^{j} & =\text { agent } i \text { 's trust in agent } j, \\
t_{\text {init } i}^{j} & =\text { agent } i \text { 's initial trust in agent } j, \\
x & =\text { the past duration of the current relation between } \\
& \text { agents } i \text { and } j, \text { and } \\
f= & \text { a parameter that takes the value of trustFactor. }
\end{aligned}
$$

Technically, a base-level of trust is desirable to keep trust from becoming 0 : if $\alpha=1$, the exponent on trust $(1-\alpha)$ is 0 , but $0^{0}$ is undefined. 
Theoretically, Hill (1990) also assumes that a certain proportion of the population will never be opportunistic, so that proportion may be taken as the agents' minimum probability-assessment that their partner will not be opportunistic; another interpretation is that this reflects a certain elementary decency in the population.

If an agent $j$, involved in a relation with an agent $i$, breaks their relation, then this is interpreted as opportunistic behavior and $i$ 's trust in $j$ decreases; in effect, $i$ 's trust drops by a percentage of the distance between the current level and the base-line level of trust; it stays there as $i$ 's new initial trust in $j, t_{\text {init, } i}^{j}$ until the next time $i$ and $j$ are matched, at which point it may start to increase again.

\subsection{Matching}

The process required to assign buyers to suppliers or to themselves, respectively, can be generated by executing a so-called 'matching algorithm'. A match is an assignment of an agent to another agent. A matching algorithm produces a set of matches (a matching) on the basis of agents' preference rankings over other agents. Each agent has to have a strict ranking of all the agents he may be matched to on the basis of his preference for being matched to each of those agents. Besides a preference ranking, each agent maintains a 'minimum tolerance level' that determines which other agents are 'acceptable', namely those agents that are somehow 'better' than the agent's minimum tolerance level; agents will not (want to) be matched to other agents they deem unacceptable. Finally, each agent has a maximum number of matches he can be involved in at any one time (a quota).

The algorithm used is Tesfatsion's (1997) deferred choice and refusal (DCR) algorithm, which extends ${ }^{2}$ Gale and Shapley's (1962) deferred acceptance algorithm. ${ }^{3}$ The DCR algorithm is used with some qualifi-

\footnotetext{
${ }^{2}$ To be precise, the DCR algorithm allows both sides of the market to be coincident, overlapping or disjoint, and it also allows arbitrarily specified offer and acceptance quotas.

${ }^{3}$ These algorithms produce stable matchings, which are matchings that have no
} 
cations. First of all, and most importantly, unlike the DCR algorithm, buyers are allowed to be matched to themselves, in which case they are their own supplier. Each buyer includes itself as one of the alternatives in its preference ranking, and suppliers not ranking higher than the buyer are unacceptable. This effectively endogenizes the buyer's preferences for different organizational forms; a buyer prefers to remain single (and 'make') rather than 'buy' from an unacceptable supplier. The argument is that buyers on industrial markets don't necessarily need a supplier to make a profit; they can choose to make rather than buy what they need. On final goods markets, the agents on both sides of the market are qualitatively different from one another: consumers are individual people but firms are groups of individuals; people can not do certain things that organizations can do. On industrial markets, the agents on both sides of the market are firms, so that a buyer-firm may perform the same functions as a supplier-firm - albeit less efficiently because the buyer does not specialize in performing those functions - and thereby economize on the costs of coordinating the transaction with the supplier-firm; determining whether the buyer-firm should or should not perform a function itself is at the heart of transaction cost economic reasoning.

Secondly, only disjoint sets of buyers and suppliers are allowed, so that there are no agents that can be buyer as well as supplier. So, although buyers may be their own supplier, they can not supply to other buyers. Finally, we allow different agents to have different quotas - i.e. different maximum numbers of matches allowed at any moment in timebecause different buyers and suppliers are likely to want different numbers of partners.

blocking (pairs of) agents, i.e. (pairs of) agents who can (bi- or) unilaterally improve upon their actual situation under the matching by - rather than to their actual match-being matched to (each other or) themselves. The DCR algorithm was used because it provides a way of assigning agents to each other, not because it produces stable matchings; in the current application, stability is just a side-effect. 


\subsubsection{The DCR Algorithm}

The DCR algorithm works as follows. Buyers may have one or more suppliers and suppliers may have one or more buyers; each buyer $i$ has an offer quota, $o_{i}(\geq 1)$ and each supplier $j$ has an acceptance quota, $a_{j}(\geq 1)$. Before the matching, all buyers and suppliers establish a strict preference ranking over all their alternatives. The algorithm then proceeds in a finite number of steps.

1. In the first step, each buyer sends up to a maximum of $o_{i}$ requests to its most preferred, acceptable suppliers. Note that the algorithm structurally favors the agents that send the requests; buyers seem more plausible than suppliers in that respect. Because the buyers typically have different preference rankings, the various suppliers will receive different numbers of requests.

2. The suppliers first reject all requests received from unacceptable buyers. Then, each supplier 'provisionally accepts' up to a maximum of $a_{j}$ requests from his most preferred acceptable buyers and rejects the rest (if any).

3. Each buyer that was rejected in any step fills its quota $o_{i}$ in the next step by sending requests to $\left(o_{i}\right.$ minus the number of outstanding, provisionally accepted, requests) next-most-preferred, acceptable suppliers that he has not yet sent a request to.

4. Each supplier again rejects requests received from unacceptable buyers and provisionally accepts the requests from up to a maximum of $a_{j}$ most preferred, acceptable buyers from among newly received and previously provisionally accepted requests and rejects the rest. As long as one or more buyers have been rejected, the algorithms goes back to step 3 .

The algorithm stops if no buyer sends a request that is rejected. All provisionally accepted requests are then definitely accepted. An exampleapplication of this matching algorithm is presented below. 


\subsubsection{An Example Application}

For an example of the operation of the matching algorithm, consider Table 3.1, which lists randomly generated preference rankings of 5 buyers

\begin{tabular}{cccccc} 
& \multicolumn{5}{c}{ supplier } \\
\cline { 2 - 6 } buyer & 1 & 2 & 3 & 4 & 5 \\
\hline 1 & 4,2 & 5,1 & 2,4 & 1,1 & 3,1 \\
2 & 1,4 &,- 2 &,- 1 &,- 2 &,- 5 \\
3 & 3,1 &,- 4 & 4,2 & 2,4 & 1,3 \\
4 &,- 3 &,- 5 &,- 5 & 1,3 & 2,2 \\
5 &,- 5 &,- 3 &,- 3 &,- 5 &,- 4 \\
\hline
\end{tabular}

Table 3.1: Example preference-rankings in Gale and Shapley's (1962) format. Buyer 1 ranks supplier 4 first, 3 second, 5 third, etc. Supplier 1 ranks buyer 3 first, 1 second, 4 third, etc.; a '-' means 'unacceptable'.

over 5 suppliers and vice versa. In addition, the buyers were placed at randomly generated positions on their own rankings (expressing their tolerance level) and suppliers whose ranking was not higher than the buyer's own ranking are not acceptable and therefore not listed.

If all agents are allowed only one partner $\left(o_{i}=a_{j}=1\right)$, the algorithm produces the following steps. Note that these steps do not correspond to timesteps in the simulation. In each timestep, the complete algorithm is executed until it stops.

1. Buyers 1, 2, 3 and 4 send requests to their most preferred suppliers, i.e. 4, 1, 5 and 4, respectively. The suppliers that receive only one request accept those provisionally, while supplier 4 rejects the request from buyer 4 and provisionally accepts the request from buyer 1 .

$\begin{array}{rrrrrr}\text { buyers } & 1 & 2 & 3 & 4 & 5 \\ \text { suppliers } & 4 & 1 & 5 & \end{array}$

2. Buyer 4 sends a request to its next most preferred supplier, 5, who accepts buyer 4's request and rejects buyer 3's already provisionally 
accepted request, because supplier 5 prefers buyer 4 to buyer 3 .

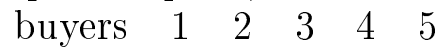

suppliers $4 \quad 1 \quad 5$

3. Buyer 3 now sends a request to its next most preferred supplier, 4, which is rejected, because supplier 4 prefers its already accepted buyer (1) to buyer 3 .

$\begin{array}{rrrrrr}\text { buyers } & 1 & 2 & 3 & 4 & 5 \\ \text { suppliers } & 4 & 1 & & 5 & \end{array}$

4. Buyer 3 now sends a request to the next supplier on its list, which is supplier 1, who accepts that request and rejects buyer 2's request, which he had previously accepted provisionally.

$\begin{array}{rrrrrr}\text { buyers } & 1 & 2 & 3 & 4 & 5 \\ \text { suppliers } & 4 & & 1 & 5 & \end{array}$

5. Buyer 2 has no more acceptable suppliers so no buyer sends another request, which stops the algorithm.

$\begin{array}{rrrrrr}\text { buyers } & 1 & 2 & 3 & 4 & 5 \\ \text { suppliers } & 4 & & 1 & 5 & \end{array}$

Buyers 1, 3 and 4 are now matched to suppliers 4, 1 and 5, respectively, while buyers 2 and 5 are matched to themselves. The algorithm is also able to handle cases where $o_{b}$ and/or $a_{s}$ are greater than 1. For example, the reader may verify that buyers $1,2,3$ and 4 will be matched to suppliers (3 and 4), (1), (1 and 5) and (4 and 5), respectively, when $o_{i}=a_{j}=2$.

\subsubsection{Matching Buyers and Suppliers}

In our model of buyer-supplier interaction, the matching algorithm is applied in each timestep of the simulation. At the start of each timestep, each agent chooses a value for $\alpha$ and for $\tau$ and calculates other agents' scores. Scores are calculated on the basis of suppliers' scale-efficiency in the previous timestep; only after the matching does it become clear to how many and which buyers each supplier is actually matched, and what the real extent of his scale-efficiency is. Expectations of the supplier's 
position on each buyer-specific learning curve, on the other hand, will already be accurate before the matching - assuming, of course, that the relation makes it through the matching.

The agents rank their alternatives on the basis of these scores: a higher score means a higher preference for being matched to this alternative. ${ }^{4}$ For a supplier this means ranking all buyers and for a buyer this means ranking all suppliers and himself. A buyer calculates his own score using efficiency $=0,{ }^{5}$ trust $=1$ and $\alpha=1$, and he is not loyal to himself. Remember that trust in intention rather than in competence is implied, so the buyer can and does completely trust himself. Trust is therefore not relevant, so $\alpha=1$; eventually, the buyer is always only interested in profit, which is also why a multiplicative specification for determining scores was used. The buyer uses this own score as his minimum tolerance level; the buyer is rather matched to himself than to suppliers whose score is not higher than the buyer's own score. Those suppliers are therefore unacceptable for the buyer. Each buyer's offer quota is set to 1 while each supplier can have more than 1 buyer.

This concludes the specification of all parameters that have to be set before the matching algorithm can proceed, which it does in every timestep of the simulation. Because the agents' preferences may change from each timestep to the next, the outcome may be different in each timestep than in the previous or the next. In particular, preferences may change because the agents' trust in each other changes, as described in Section 3.2.3, or because the agents change the value they use for $\alpha$ and/or $\tau$. The way they adapt these values is discussed in the next section.

\footnotetext{
${ }^{4}$ Draws from randomdistributions are used to settle the ranking of alternatives with equal scores.

${ }^{5} \mathrm{~A}$ buyer is not allowed to produce for and supply to other buyers (his competitors), so he can not generate scale-economies. Learning-by-doing is also not possible for the buyer, because savings resulting from this are assumed to be related to the advantage due to the cognitive distance between the buyer and his supplier (cf. Nooteboom's (1992) external economies of cognitive scope, and the simulations by Péli and Nooteboom (1997)).
} 


\subsection{Adaptation}

As explained in Section 2.2.1, an agent in a Complex Adaptive System (CAS) is adaptive if "the actions of the agent in its environment can be assigned a value (performance, utility, payoff, fitness, or the like); and the agent behaves in such a way as to improve this value over time" (Holland and Miller 1991, p. 365). The adaptive character of the artificial agents in the model refers to the possibility for the agents to change the value they use for $\alpha$ and $\tau$ from each timestep to the next, which may lead to changes in the scores they assign to different agents and to different preference rankings. The agents use reinforcement learning to adaptively search the space of possible combinations of values for $\alpha$ and $\tau$.

\subsubsection{Choosing $\alpha$ and $\tau$}

Each agent can use several possible values for $\alpha \in[0,1]$ and for $\tau \in$ $[0,0.5]$. To each of these values, each agent assigns a 'strength', ${ }^{6}$ which expresses the agent's confidence in the success of using that particular value; the various strenghts always add up to constants $C_{\alpha}$ and $C_{\tau}$, respectively. The idea is that the strength of values that lead to high performance increases, which leads to a higher likelihood that those values are going to be used again, and vice versa. This is Thorndike's law of effect; the mechanism is also called reinforcement learning.

At the start of each timestep, each agent chooses values to be used for $\alpha$ and $\tau$ in calculating scores. The choice between the different possible values is probabilistic with selection probabilities equal to relative strenghts, i.e. strengths divided by the total of strenghts, $C_{\alpha}$ and $C_{\tau}$, respectively. Imagine a wheel of fortune with as many slots as there are values, with the size of each slot proportional to the values' strenghts: the value with the highest strength has the largest slot, the value with the second highest strength has the second largest slot, etc. At the start

\footnotetext{
${ }^{6}$ See (Arthur 1991, Arthur 1993, Kirman and Vriend 2001, Lane 1993) for discussions and applications of these so-called 'classifier systems' to models in economics; good general introductions are (Booker et al. 1989), (Goldberg 1989) and (Holland et al. 1986).
} 
of each timestep, each agent spins his roulette wheels (one for $\alpha$ and one for $\tau$ ) and uses the values for $\alpha$ and $\tau$ the wheels stop at.

\subsubsection{Updating}

The strengths of the values that were chosen for $\alpha$ and $\tau$ at the start of a particular timestepe are updated at the end of that timestep, on the basis of the agent's performance during that timestep, which is assumed to be related to the values used for $\alpha$ and $\tau$. Updating means that the agent adds the profit obtained during the timestep to the strength of the values. After this, the strengths are renormalized to sum to $C_{\alpha}$ and $C_{\tau}$ again (see (Arthur 1993) for a discussion of this learning mechanism). This is done by multiplying each of them with the ratio $C /(C+$ profit $)$, where $C=C_{\alpha}, C_{\tau}{ }^{7}$ At this point, as an output of the simulation, each agent $i$ 's weighted average value for $\alpha_{i}$ (the 'profit-elasticity' of the scores that $i$ assigns) and for $\tau_{i}$ ( $i$ 's loyalty) is calculated:

$$
\text { w.a. } \alpha_{i}=\sum_{\alpha_{i}=0, \ldots, 1} \alpha_{i} \cdot \operatorname{strength}\left(\alpha_{i}\right)
$$

and similarly for w.a. $\tau_{i}$. This indicates where $i$ 's emphasis lies: because the value with the highest strength pulls the weighted average in its direction, the emphasis lies on low values for $\alpha$ if the weighted average $\alpha_{i}$ is low and vice versa, and similarly for $\tau$. Each agent explores the fitnesslandscape on his own two-dimensional problem space, with $\alpha$ and $\tau$ as dimensions. The weighted averages indicate where the agent is located in his problem space. It is important to realize that agents are always located at one of the 25 points on the 2 -dimensional grid, but that this is hard to visualize, which is why weighted averages are used as indications. What makes it a difficult problem is not the fact that the problem space

\footnotetext{
${ }^{7}$ In the simulation, the $C$ 's are not actually constant, because the profit obtained is simply added to the previous strength. The roulette wheel increases in size, but slot sizes remain proportional to relative strengths, so the effect is the same as with renormalization. This was done because with longer runs of the simulation, some relative strenghts tended to become so small, that they caused a runtime error in the program.
} 
is large, but the fact that the fitness-landscape is not static, because it is coupled to other agents' choices.

\subsection{Summary}

This section will summarize the main points of the simulation as a reference guide, by means of the flowchart in Figure 3.3. This figure shows how the main loop is executed in each of a sequence of discrete 'timesteps'. This sequence is called a 'run', which itself may be repeated a number of times, to average out the influence of draws from random distributions on the results. The number of timesteps in a run and the number of runs in an experiment are parameters set by the user of the program.

In the step 'Initialize simulation', certain parameters are set for the simulation as a whole. The number of buyers and suppliers has to be specified, as well as the number of runs and the number of timesteps in each run. The program's random number generator is seeded and finally, the agents are instantiated (created) and given a number for identification. At the start of each run, each of the agents is initialized. For example, the agents' profits (from the previous run) are re-set to zero and the agents' trust in other agents is re-set to an initial value, which is a parameter in the simulation. After this agent-initialization, the actual simulation starts, consisting of a sequence of timesteps as described above.

In each timestep, before the matching takes place, each agent chooses values for $\alpha$ and $\tau$ to calculate scores with (see Section 3.4.1), calculates scores (see Section 3.2), and ranks alternative partners on the basis of these scores. Then, the agents are matched by the matching algorithm (see Section 3.3) and for each pair of agents, their situation after the matching is compared to what it was before the matching. Any one of three events may have occurred: ${ }^{8}$

Start: two agents start a relation if they are matched to each other by

\footnotetext{
${ }^{8}$ If two agents are matched to each other neither before nor after the matching, then there is, of course, no event in a relation's life-cycle that this corresponds to.
} 
the matching in a certain timestep, while they were not matched before the matching.

Continue: two agents continue a relation if they are matched to each other by the matching in a certain timestep, while they were also matched to each other before the matching. If a relation continues, the agents' trust in each other increases, as does $e_{l, j}^{i}$, supplier $j$ 's efficiency due to his experience in using assets which are specific to buyer $i$ (see Section 3.2.2).

Break: a relation breaks if, while two agents were matched to each other before the matching in a certain timestep, either the buyer did not send a request to the supplier or he did, but the supplier rejects the request. If a relation breaks, the trust of the agent who did not break the relation in the agent who did, decreases, and the supplier's efficiency due to his experience with the buyer drops to 0 .

After the matching, suppliers that are matched to a buyer produce for and deliver to that buyer, while suppliers that are not matched do nothing; buyers that are not matched produce for themselves. Then, the buyers sell their products on the final-goods market - whether produced by their supplier or by themselves. They share the profit they make with their supplier, if they have one. Finally, all agents use that profit to update the strenghts of the values they used for $\alpha$ and $\tau$ (see Section 3.4.2). 


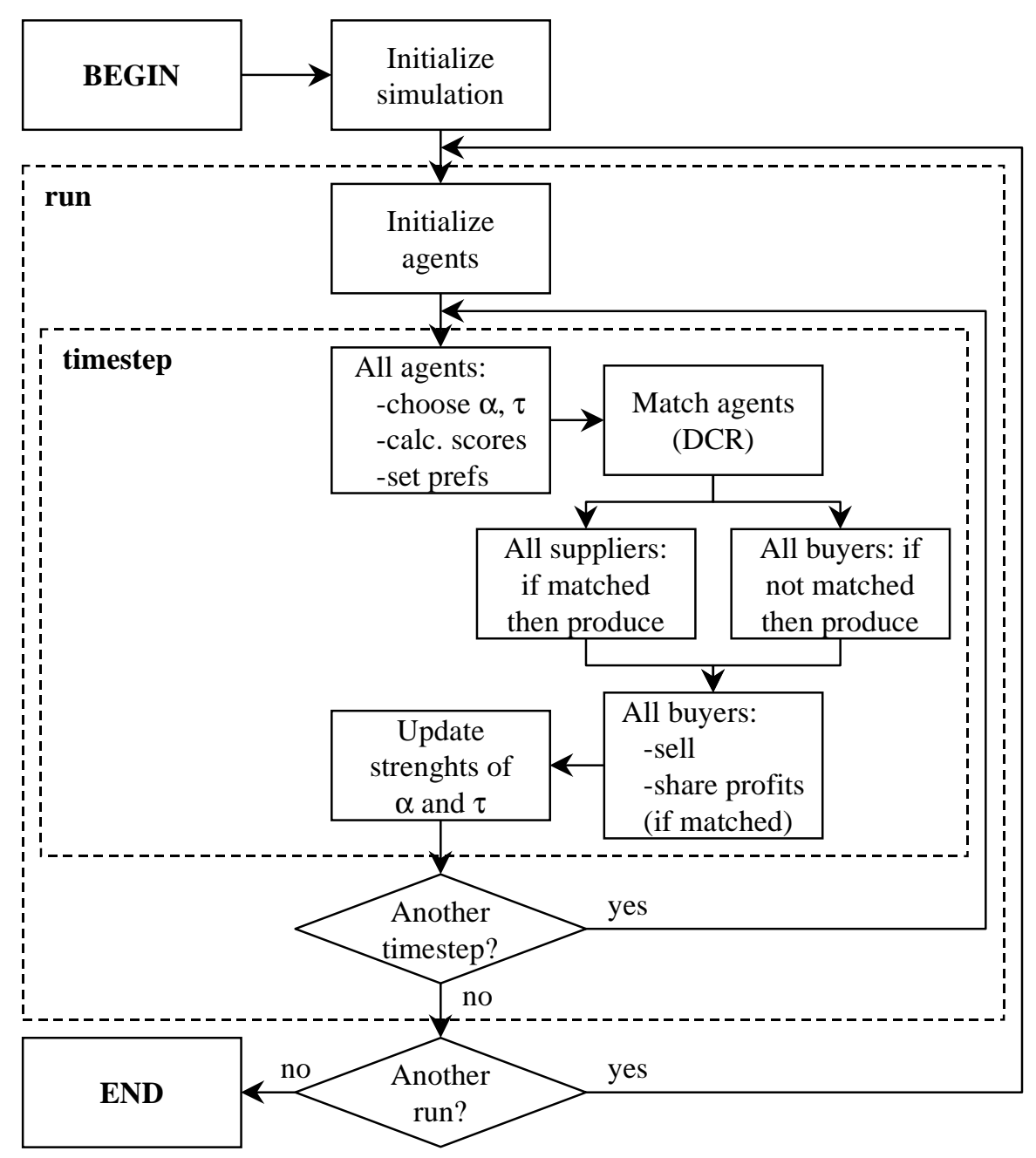

Figure 3.3: Flowchart of the simulation. 


\section{Chapter 4}

\section{Results}

What we now have is an artificial society in which we can 'grow' social structures (Epstein and Axtell 1996). This particular virtual laboratory or CompuTerrarium captures situations where problems of economic organization can be solved, by choosing among different structural forms for organizing transactions.

It was developed to investigate (the outcomes of) the process in which multiple, boundedly rational agents adaptively learn to make this choice. The focus is on this process, because that is believed to be necessary to be able to explain and predict which organizational forms are used for different transactions. It is not considered relevant to do a rational analysis of which forms should optimally be used, for the reasons explained in Chapter 2. If one wants to allow for the information generated during the course of bilateral exchanges to play the role it deserves and, consequently, for trust and differential preferences to develop (which one has to do for the reasons given in Chapter 1), then one has to model those bilateral exchanges and the individual agents involved in them. Here, it has been chosen to do so by building the agent-based model described in Chapter 3 and simulating the model on a computer.

Several issues are addressed in this chapter. First of all, the model was primed (Section 4.1). Before a model can be used, the extent has to be established to which changes in the parameters and the structure of the model cause changes in the results. If the results are highly sensitive, 
then they are not very robust and conclusions can not be drawn from them with much confidence; if, alternatively, the results are not sensitive to changes in the parameters, then those parameters do not 'work'. The same holds for changes in the architecture of the model. The difference with experimental variables is that if results are not sensitive to- do not depend on - changes in those, then this is a result. A model can be used to answer the question of what the influence on the results is of a change in one or more experimental variables; the answer 'none' is as interesting an answer as other answers are.

Results from the first series of experiments with the model are reported in Section 4.2. This experiment allowed an initial test of the plausibility of the model, which was assessed by examining whether a particular (undisputed) result from TCE would emerge. This is the relation between increasing asset specificity and more insourcing relative to outsourcing.

With confidence in the sensitivity and plausibility of the model, the two main points of criticism of TCE can be examined, one with respect to TCE's assumption rather than investigation of optimal outcomes (Section 4.3), and the other with respect to the role of trust and loyalty next to opportunism (Section 4.4). Finally, we leave the comparison and confrontation with TCE behind and move to experiments that our model does and TCE does not allow and for which there is, therefore, no way to make a comparison with TCE. An initial exploration of some more of these dynamics of the model was started in Section 4.5; in fact, towards the end of this thesis, the real work of systematically exploring the model developed here is just about to begin. This illustrates how the emphasis in this thesis has been on developing the approach and a suitable model, rather than on applying it.

\subsection{Priming the Model}

The simulation model described in Chapter 3 did not come about instantly; it was developed over the course of a period of time. During the development of the model, results were constantly generated, and con- 
clusions from those results were fed back into the model-development. ${ }^{1}$ From the perspective of the current version of the model, this has resulted in a number of decisions concerning the construction of the model and the setting of parameters. Apart from giving interesting insights into the model and what it represents in its own right, this 'sensitivity analysis' has led to the parametersetting for an initial set of experiments as listed in Table 4.1. The complete list of parameters and variables is given in Table C.1 in Appendix C, along with the value range allowed for each. Some of the changes made to the model over the course of its development are discussed below. The parameter-setting in Table 4.1 was used in the experiments reported in Section 4.2.

Each simulation run involves 12 buyers and 12 suppliers and lasts for 500 timesteps. At several locations in the model, numbers are drawn from pseudo-random number generators. For example, such draws are necessary to settle the ranking of alternatives to which equal scores are assigned, as explained in Section 3.3.3. They are only required for practical purposes, however; they have no meaning in themselves. In establishing the preference-ranking, it does not matter which of two or more agents to whom the same score was assigned is placed higher on the ranking; what matters is that the ranking is established. Simply using the numbers that identify agents to solve this problem would lead to agents identified by lower numbers to gain a systematic (dis-)advantage over agents identified by high numbers, so the assignment is randomized. Another example is that, in selecting values for $\alpha$ and $\tau$, each agent needs to draw two pseudo-random numbers. It is irrelevant which particular number it is; what matters is that values for $\alpha$ and $\tau$ are chosen and which values

\footnotetext{
${ }^{1}$ The roots of the model can be traced back to one I worked on with John Miller and Kathleen Carley while I visited Carnegie Mellon University in early 1996. Results from previous versions of the model were presented at the 1997 workshop on Computational and Mathematical Organization Theory in San Diego, at the Society for Computational Economics' 1998 and 1999 annual conferences on Computing in Economics and Finance in Cambridge (UK) and Boston, respectively and at the European Association for Evolutionary and Political Economy's 1998 annual conference in Lisbon, and were published as SOM Research Reports 97B53 and 99B41, (Klos and Nooteboom 1998), and (Klos and Nooteboom 2001). The results presented here have not yet been presented or published elsewhere.
} 


\begin{tabular}{rlr} 
& parameter/variable & $\begin{array}{r}\text { value used } \\
\text { (cf. Table C.1) }\end{array}$ \\
\hline general & number of buyers, $I$ & 12 \\
& number of suppliers, $J$ & 12 \\
& number of runs, $R$ & 25 \\
& number of timesteps, $T$ & 500 \\
& number of values for $\alpha \in[0,1]$ & 5 \\
& number of values for $\tau \in[0,0.5]$ & 5 \\
& renormalization constant $C_{\alpha}$ & $3 d_{i}$ \\
& renormalization constant $C_{\tau}$ & $3 d_{i}$ \\
& baseTrust, $b$ & 0.3 \\
& initTrust(subject) & 0.75 \\
& trustFactor & 0.5 \\
\hline per & differentiation, $d_{i}$ & 1 \\
\hline buyer $i$ & offer quota, $o_{i}$ & 3 \\
per & acceptance quota, $a_{j}$ & 0.5 \\
supplier $j$ & scaleFactor & 0.5
\end{tabular}

Table 4.1: Parameters and variables used in the simulation.

are chosen more often than others. It would also have been possible to simply pick the value with the largest strength, but that would leave the agents too little room for exploration, because the first value chosen may then be chosen forever thereafter. The point is that pseudo-random numbers can be used to solve problems, but they do have an effect on the results. In order to diminish this influence, each run is repeated a number of times (25), and results are (sometimes) presented as averages across those 25 runs (and across all agents). In other cases, the focus is on the individual run or on the characteristics of the individual agents involved. 


\section{Learning}

The speed of learning of the reinforcement learning algorithm that the agents use depends on the size of the renormalization constant, relative to the increases, and on the number of available alternatives to choose from (cf. Arthur 1993). Strengths are increased with realized profit, which depends on product differentiation, among others. For this reason, the renormalization constants have also been made dependent on the value used for $d$. In particular, three times the value of $d$ was used to initialize the strenghts of the different values for $\alpha$ and $\tau$; when $d=0.35$, for example, $C_{\alpha}=C_{\tau}=1.05$. Each possible value was assigned a strength equal to the appropriate value of $C$ divided by the number of strengths, i.e. the number of values for $\alpha$ and $\tau-5$ in the experiments. Initially, fixed values were used for $C$, but this resulted in a learning process whose sensitivity to changes in the experimental variable, $d$, varied with $d$. Because increases in strengths consist of realized profit, lower increases occurred in experiments with lower values for $d$; the agents did not get the opportunity to explore, but locked in to the region in the problem space they were plugged into at the start of the simulation.

Furthermore, only values between 0 and 0.5 were allowed for $\tau$, because higher values had too high an influence on the results. If there are 5 possible values between 0 and 1 , then choosing either one of the three highest values results in a score-advantage of the current partner of at least 0.5. This is an advantage that alternative partners can almost never surpass, which means that agents very often stick to their first partner, into which situation the simulation then locks in. Using only values for $\tau$ between 0 and 0.5 gives the agents room to experiment with different values without getting locked into their initial situation.

\section{Initial Trust}

Furthermore, each agent's initial trust in another agent was set at 0.75. It needs to be this high, because otherwise suppliers can never be more attractive than a buyer considers himself. Initially, suppliers enjoy no economies of scale or experience, so buyers have to be attracted to them 
by trusting them highly and by weighting profitability relatively low. If initial trust is not set high enough, buyers never prefer suppliers and nothing ever happens in the simulation.

It could be argued that the buyers should foresee suppliers' scale economies and have a higher preference for them on that basis. The observation above has wider implications, however. The issue is that the advantages of the market in terms of scale-economies that TCE assumes do not come about instantly and only under certain circumstances. Time has to be allowed for these advantages to build up and this observation also forces one to allow for the fact that sometimes they do not even build up at all. More generally, studying economic systems at the level of individual agents and the relations among them focuses attention on the way these kinds of micro-motives influence macro-behavior (Schelling 1978).

\section{Quota}

Finally, each buyer's offer quota was fixed at 1, and each supplier's acceptance quota was set to 3, which means that each buyer has a supplier or he does not, in which case he supplies to himself, and that each supplier can supply to a maximum of 3 buyers. In previous experiments with each supplier $j$ 's acceptance quota $a_{j}$ set to the total number of buyers $I$, the system quickly settled in a state where all buyers buy from the same supplier. For this reason, suppliers were only allowed a maximum of three buyers. This limits the extent of the scale economies that suppliers can reach - the consequences of this decision are elaborated on below.

\subsection{Adaptive Economic Organization}

In a first series of experiments, the aim was to test whether the model was able to reproduce the relation between increasing asset specificity and more insourcing relative to outsourcing. This would lend credibility to the model, because it is a known relation that is also used in TCE. Because asset specificity is related to product differentiation, the value of 
$d$ was varied in 6 experiments: $d=0.25,0.35, \ldots, 0.75$. Before going to the results, however, it is worthwhile to consider what may be expected from the simulations.

The experimental variable 'differentiation' of the buyers' products is tied to the specificity of the assets that suppliers invest in to support their production for those buyers. Initially, therefore, the buyers are confronted with the score-differentials given in Table 4.2, and repre-

\begin{tabular}{crrrrr} 
& \multicolumn{5}{c}{$\alpha$} \\
\cline { 2 - 6 }$d$ & 0.00 & 0.25 & 0.50 & 0.75 & 1.00 \\
\hline 0.25 & 0.50 & 0.23 & 0.06 & -0.05 & -0.13 \\
0.35 & 0.40 & 0.17 & 0.01 & -0.10 & -0.18 \\
0.45 & 0.30 & 0.11 & -0.04 & -0.15 & -0.23 \\
0.55 & 0.20 & 0.03 & -0.10 & -0.20 & -0.28 \\
0.65 & 0.10 & -0.04 & -0.16 & -0.25 & -0.33 \\
0.75 & 0.00 & -0.12 & -0.22 & -0.30 & -0.38 \\
\hline
\end{tabular}

Table 4.2: Difference between suppliers' initial scores and a buyer's own score $(=d)$ for different values of differentiation and of the buyer's $\alpha$.

sented graphically in Figure 4.1. The values in Table 4.2 are calculated as follows. The score that a buyer $i$ assigns to a supplier $j$, is (see Section 3.2$)$ :

$$
\operatorname{score}_{i j}=0.5\left(d_{i}+d_{i} e_{l, j}^{i}+\left(1-d_{i}\right) e_{s, j}\right)^{\alpha_{i}} \cdot t_{i}^{j(1-\alpha)} .
$$

Note that the buyer's profit in a relation with a supplier is only half the total profit that is made in the relation. The score that buyer $i$ assigns to himself is equal to $d_{i}$, because that is his profit when he makes and he uses $\alpha=1$ to calculate his own score (see Section 3.3.3 for the reason for this). The values in the table give the difference between these two, in the first timestep of the simulation, when all these values are the same for all buyers.

As differentiation increases, the number of distinct values for $\alpha$ that yield a net score-advantage for suppliers - which they need for buyers to consider them acceptable-decreases, so we may expect less outsourcing 


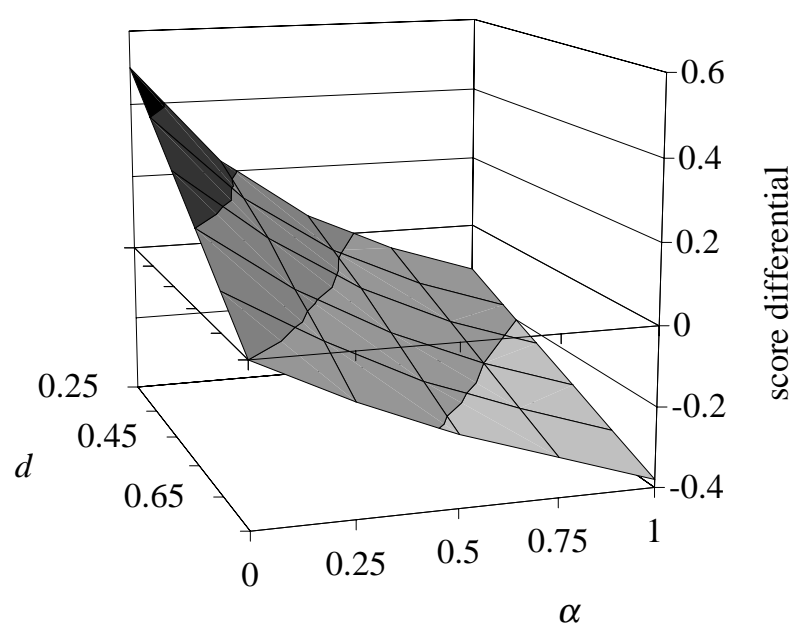

Figure 4.1: Score differentials in Table 4.2. This graph shows the advantage to suppliers in the first timestep of the simulation for different combinations of $d$ and $\alpha$.

when differentiation increases. If $d=0.75$, there is no value for $\alpha$ that gives suppliers a net advantage so we may expect no outsourcing at all in that case. ${ }^{2}$ Notice that for any $d<0.75$, no matter how much smaller, the suppliers do have a net advantage which, as soon as matches occur, may increase when suppliers' economies of scale and experience increase as they supply to more than 1 buyer and in longer-lasting relations. The situation in Table 4.2, therefore, is likely to shift in favor of suppliers as time progresses. In general, then, we would expect more making (and less buying) when differentiation is increased in the different experiments. This corresponds to TCE's predictions about this relation. We would also expect the proportion outsourced to increase over time in each individual run. Note that while the second prediction can not be compared to TCE, because time is involved, the first prediction corresponds to TCE, as derived from the characteristics of the relations between several variables uses in TCE, that were also incorporated in our agent-based simulation

\footnotetext{
${ }^{2}$ In initial runs of the experiment, this was confirmed, which is why the experiment $d=0.75$ is not reported.
} 
model. This does not mean that we would predict optimal outcomes to emerge or that we can even assess what those are, but just that some of the characteristics of the outcomes we predict will correspond to the outcomes TCE would predict. Also note that the type of model we use allows us to make hypotheses about the sequencing of events. Knowledge generated this way leads to the understanding about how processes lead to outcomes that is necessary to design interventions in processes with the purpose of influencing outcomes (cf. Nooteboom 2000, see Section 2.2)

The proportion of economic activity under hierarchichal (as opposed to bilateral) governance in the different experiments is shown in Figure 4.2. Each line represents one experiment, corresponding to a value

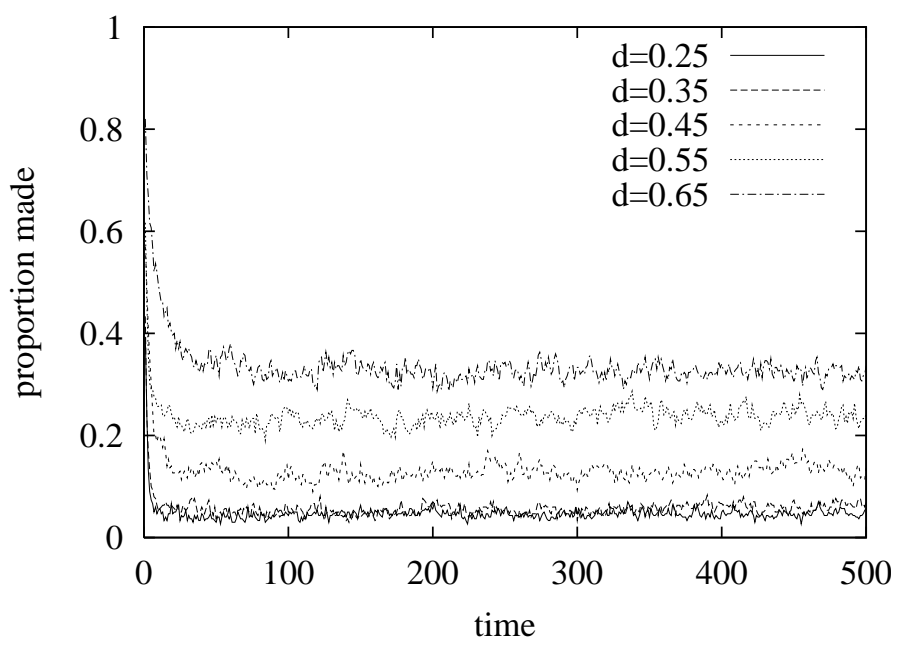

Figure 4.2: Proportion 'made' (as opposed to 'bought').

for $d$. The graph shows the proportion of all production that is carried out by the buyers rather than by suppliers, averaged across 25 runs. As expected, the proportion made is higher when differentiation is high than when it is low. Also, the proportion made decreases initially, which was also expected, because the advantage to outsourcing only increases over time from the initial values given in Table 4.2, as explained above. In addition, for lower values of differentiation, there are more immediate returns to outsourcing, because suppliers can generate scale economies 
right away. For higher values of differentiation, outsourcing is only preferred as relations last longer and suppliers are able to generate economies of learning in the production for individual buyers. This is apparent as the slower decrease in the proportion made for higher values of differentiation than for lower values, where the gains from trade due to economies of scale can be reaped right away; it takes time for long-lasting relations (which are the prime source of outsourcing-advantage when differentiation is high) to prove their worth. It also takes time for buyers to find a partner to build up the long-lasting trust relation with that they need for generating economies of learning.

This is a second occasion on which we can point to the importance of market-making: a market has to be made before it can be used, and the process in which it is made by the participants involved has important characteristics of its own. When $d$ is low, economies of scale are important and it matters whether or not a situation arises in which a small number of suppliers each supply to a large number of buyers. The buyers a supplier supplies to may differ from each timestep to the next-what matters is the number of buyers involved. When $d$ is high, economies of learning are important and the identity rather than the number of buyers involved matters. This is the situation when the more efficient structures can only be built on time.

\subsection{Optimal Outcomes?}

With confidence in the model on the basis of the plausibility test in the previous section, we are now able to confront our model with TCE. Recall that there were two main points of criticism. The first is that TCE uses a rational analysis to predict what boundedly rational agents will do, and the second is that TCE ignores the role of trust next to opportunism. The first of these issues is addressed in this section; the second in the next section (4.4).

A model was constructed that involves individual agents. They are confronted with problems of organizing and given a decision-making apparatus and the ability to adapt their decision-making behavior to what 
they perceive to be successful. This allows us to investigate whether the optimal outcomes that TCE hypothesizes will in fact arise. We have chosen to do this by studying the buyers' profits. These profits in each of the experiments, again averaged across the 12 buyers and across 25 runs of each experiment, are shown in Figure 4.3. This figure shows that

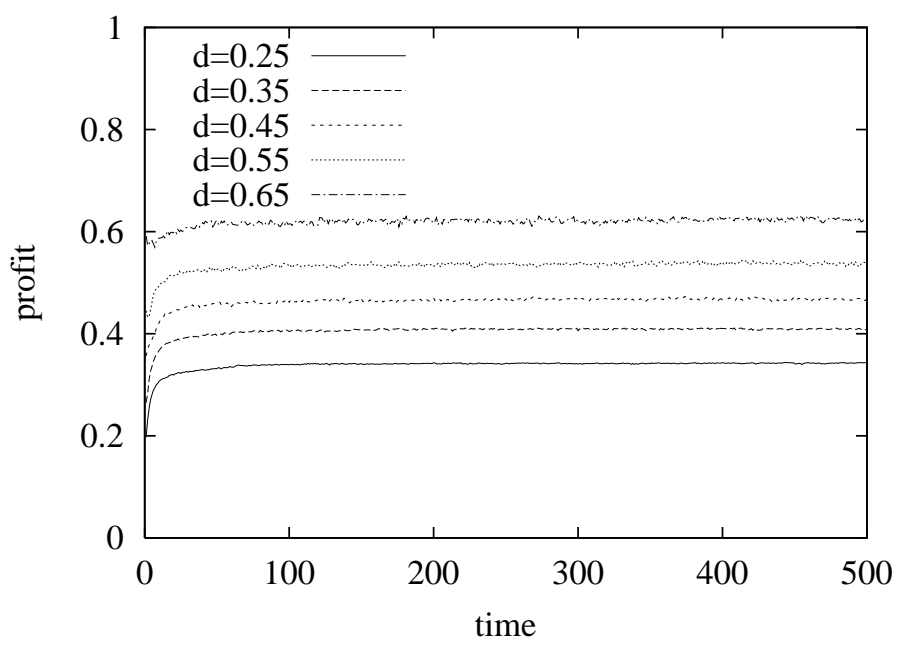

Figure 4.3: Buyers' profits.

buyers do better when differentiation is high, but they also obtain higher absolute returns in that case- profits are a function of differentiation. The picture can be made clearer and experiments can be compared when this phenomenon is compensated for. This can be done by normalizing profit, i.e. by dividing the buyers' profits by the maximum profit they can potentially make in each experiment, which also depends on the current value of differentiation. The maximum attainable profit is the profit a buyer makes when he outsources to a supplier with whom he has an infinite relation (in order to generate maximum economies of learning) and who supplies to an infinite number of buyers (in order to generate maximum economies of scale). The latter factor, however, is limited by the fact that the suppliers' acceptance quota is set to 3 , as mentioned above. When this is taken into account and each buyer's profit is divided by his profit in an infinite relation with a supplier with 3 buyers, Fig- 
ure 4.4 emerges - notice that the $y$-axis was re-scaled to $0.5-1$ to make

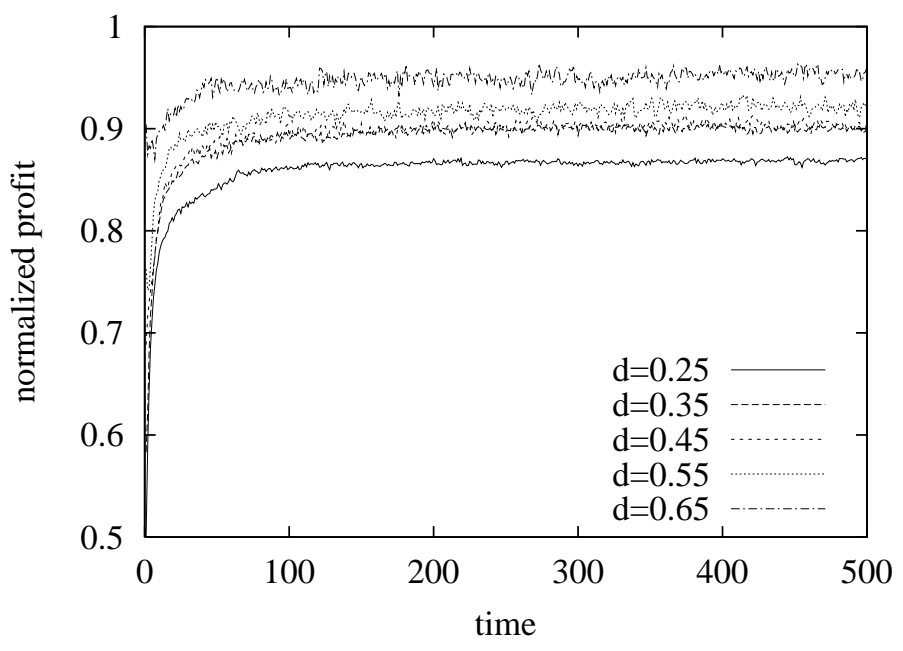

Figure 4.4: Buyers' normalized profits.

these results clearer.

If differentiation is higher, the buyers are organizing closer to their optimum. In all cases, the gains from trade defined in the model dictate that the optimum is to outsource. Even though the proportion outsourced is highest when differentiation is low (Figure 4.2), the buyers are furthest away from their optimum in that case! The reason is that it is not just outsourcing that is required, it also matters which supplier is outsourced to - this has to be a supplier that supplies to 2 other buyers at the same time, so as to be able to attain the maximum scale efficiency in the denominator of the ratio that normalized profit is. This is especially important when differentiation is low, because asset specificity is then low as well, so there are relatively many general purpose assets on which scale economies operate. The optimum can therefore be defined as a situation in which the 12 buyers together outsource to 4 suppliers, each of whom supplies to 3 buyers. This is not a common network configuration, as witnessed by Figure 4.5, which shows the buyers' normalized profits in each of the 25 individual runs of the first experiment $(d=0.25)$. In some of the runs, the required network configuration emerges, but in 


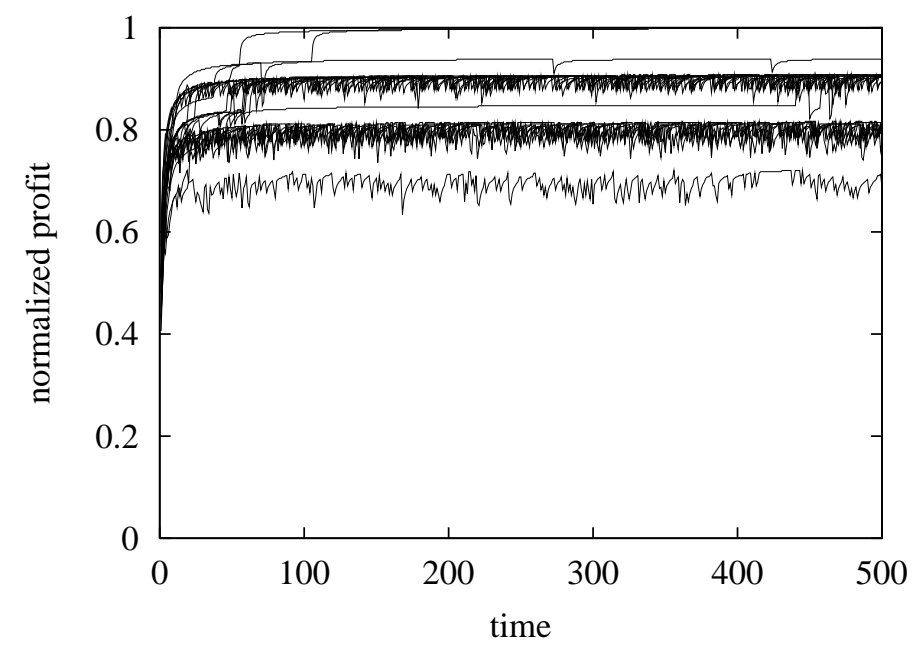

Figure 4.5: Buyers' normalized profits in 25 individual runs of experiment $d=0.25$.

most runs it does not. Average normalized profits stabilize at several levels; lower levels corresponding to more suppliers being involved and less scale economies being generated on the whole. At the highest level, reached in only 2 out of 25 runs, the 12 buyers outsource to 4 suppliers (with their maximum of 3 buyers each) and no buyer makes anything. The average across these 25 experiments (approximately 0.87 ) is the line ' $d=0.25$ ' in Figure 4.4.

When $d$ is higher, buyers organize closer to the optimum. While the optimum - in terms of efficiency - always dictates outsourcing, these buyers outsource less and still organize closer to the optimum. The reason is that the advantage to outsourcing is lower when $d$ is high than when $d$ is low, because although there are more profits to be made, they also have to be shared with the supplier. In addition, it takes time for the market's advantage to materialize, and the buyers are also more dependent upon their supplier. A break in a relation has serious consequences in this case, because the economies of learning that the supplier has built up are lost, and can only be rebuilt in time. When $d$ is low, on the other hand, any supplier is as good as the next, in this respect, just as long 
as he also supplies to several other buyers. When $d$ is high, the buyers are more in control of their own performance when they make than when they outsource.

\subsection{Adaptive Agents}

The second point of criticism of TCE, next to its assumption rather than investigation of optimal outcomes that was addressed in the previous section, is how it ignores the fact that trust and loyalty may build up between individual agents. It does this because it would be too complex to include the influence of information generated during the course of bilateral exchange. Fortunately, we now have a model of invididual agents and concrete bilateral exchanges, that allows us to do precisely that. These results are discussed in the current section.

The buyers adapt the value they use for $\alpha$ and $\tau$. As explained in Section 3.4.2, the weighted averages of $\alpha$ and $\tau$ for each agent indicate the emphasis they put on other agents' profitability vs. their trust in those other agents and on their own loyalty. The agents' learning can be represented as an adaptive walk across the fitness-landscape on the multidimensional problem space that is defined by $\alpha$ and $\tau$. Such adaptive walks are illustrated in Figure 4.6. This figure shows the combinations of weighted averages for $\alpha$ and $\tau$ (see equation 3.9) on the $x$ - and the $y$-axis, respectively, that each of the 12 buyers in experiment $d=0.25$ maintains through time. Each agent starts at coordinates (w.a. $\alpha$, w.a. $\tau$ ) $=(0.5,0.25)$ in the center of the graph; this is the average when $C_{\alpha}$ and $C_{\tau}$ are distributed evenly across the 5 possible values allowed - in $[0,1]$ for $\alpha$ and in $[0,0.5]$ for $\tau$. Although they all start at the same position, the agents follow different trajectories through the problem space. At the start of those, the agents take relatively large steps through the problem space, in search for better performance. These large steps are possible initially, because the strengths associated with the different values for $\alpha$ and $\tau$ and therefore the probabilities of each of these possible values being chosen, are still more or less equal. The large steps occur because each agent's environment still changes radically from each timestep to 


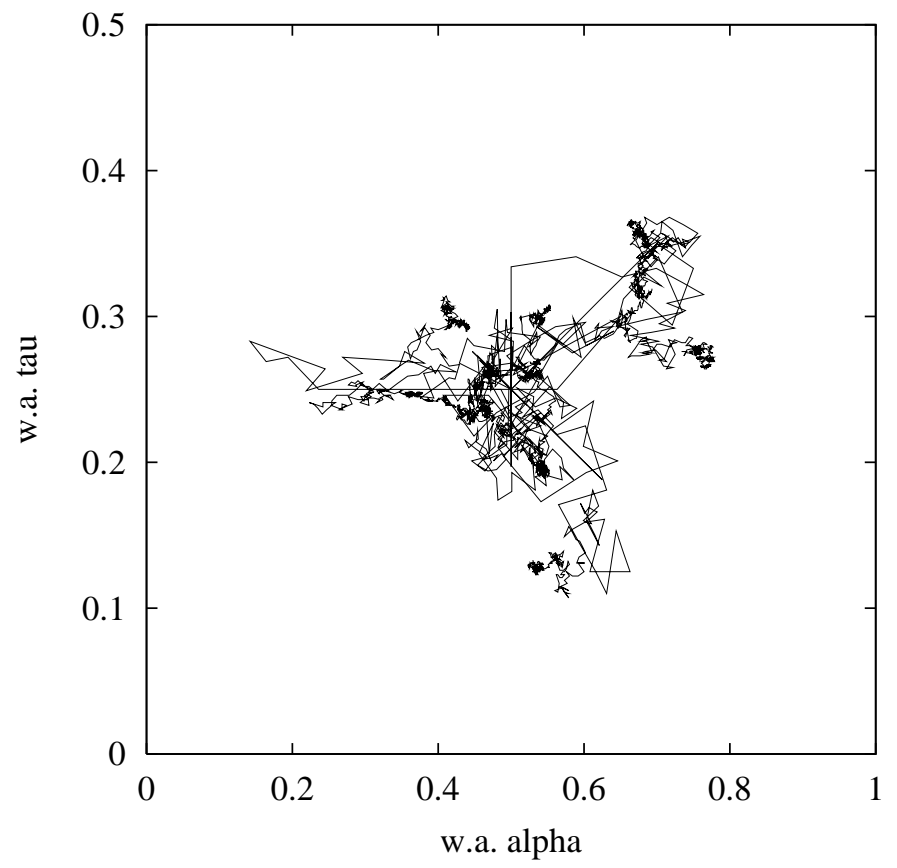

Figure 4.6: The 12 buyers' adaptive learning in the space of $\alpha$ and $\tau$ in the first run of experiment $d=0.25$.

the next. As the agents form progressively better internal models of their environment, their behavior becomes less erratic and the steps they take from each timestep to the next become smaller.

The three different types of trajectories in Figure 4.6 suggest that there may be locations in the space that attract the agents. Before firm conclusions can be drawn about those, however, the system should be studied more carefully and using the appropriate apparatus. What can already be noted is that it is apparently possible for different agents to develop different behaviors, while all of them still progress to higher levels of performance. This is indicated, for example, in Figure 4.7, which shows the plot of the 12 buyers' profits and their weighted average $\tau$, in the same run as depicted in Figure 4.6. The performance that an agent obtains depends not only on his own behavior, but also on the behavior of the 


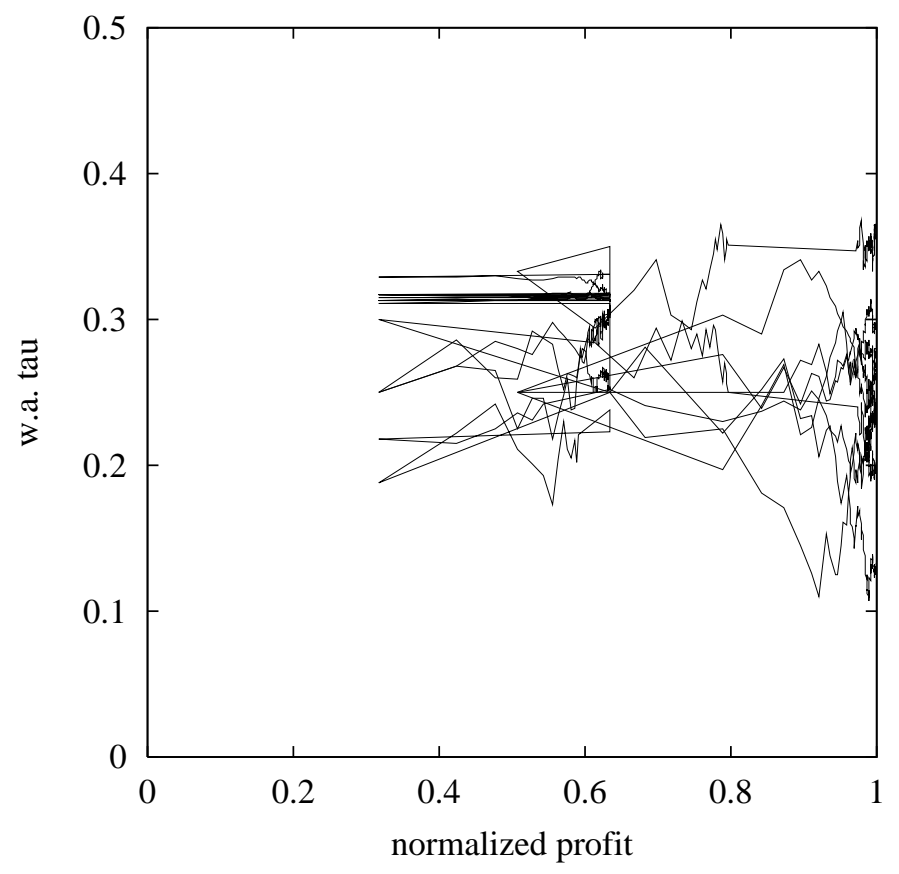

Figure 4.7: The 12 buyers' normalized profits and weighted average $\tau$ in the first run of experiment $d=0.25$.

other agents in the system. The system could be though of as annealing over time, leading to a state in which the agents are all attuned to one another. The extent to which such a state is stable to 'invasion' by other types of agents is the subject of current work.

In Figure 4.8, the graphs for the individual buyers in Figure 4.6 (taken from the first run of experiment $d=0.25$ ), are averaged and compared to the averages across the other 24 runs of the experiment. Note that a great deal of information is lost in this aggregation. It can easily be seen how averaging sweeps all the variation at the level of the individual agents (as illustrated in Figure 4.6, for example) under the rug. Because the trajectories that the individual agents follow through time lead away from the starting point in the center of Figure 4.6 in different directions, averaging inevitably leads to values around the center. In order to vi- 


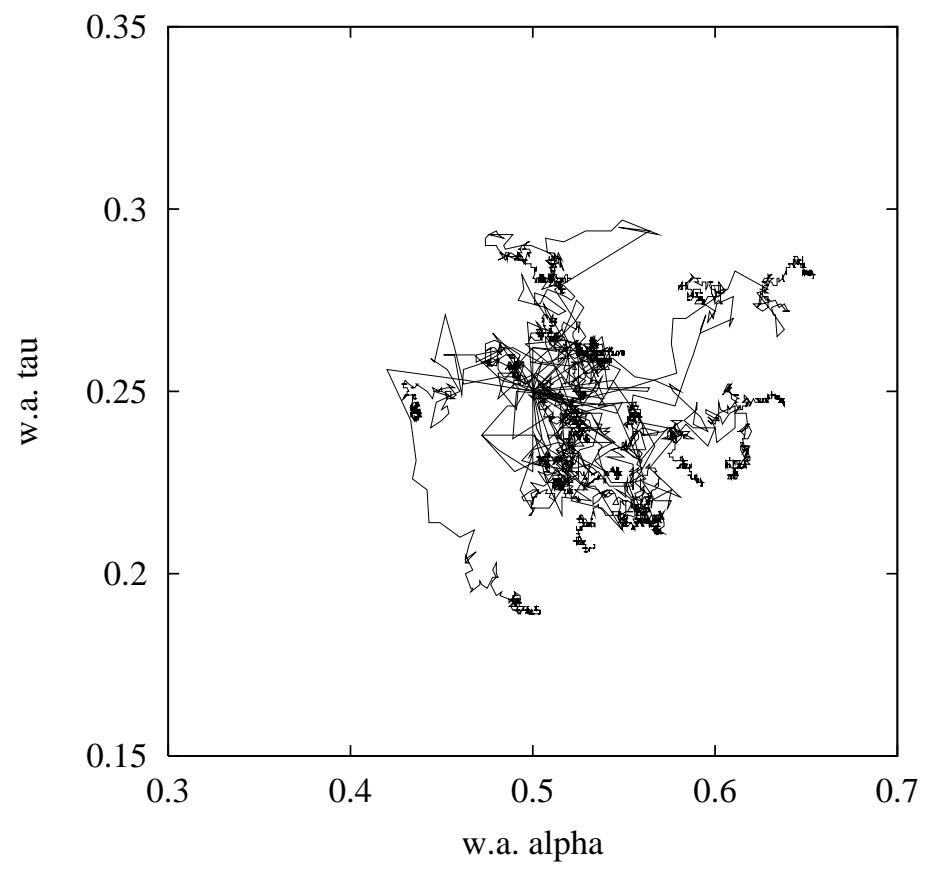

Figure 4.8: Buyers' adaptive learning in the space of $\alpha$ and $\tau$ in each of 25 runs of experiment $d=0.25$.

sualize roughly the same amount of variation as in Figure 4.6, it was necessary in Figure 4.8 to rescale both the axes. The center of the search space was kept in the center of the graph, the $x$-axis was rescaled from $0-1$ to $0.3-0.7$ and the $y$-axis from $0-0.5$ to $0.15-0.35$. It would be interesting to find out in more detail precisely which global regularities emerge from the individual agents' motivations and how, but to systematically analyze the enormous amounts of data generated at the level of the individual agents would constitute a new line of inquiry by itself. The current research has aimed at the development of the agent-based computational approach to transaction cost economics issues; systematic exploation is beyond the scope of this thesis. 


\subsection{Alternative Initialization}

In previous sections, the plausibility of the model has been tested and results from the model have been analyzed in the areas of the two points of criticism of TCE. We are now ready to leave TCE behind altogether and to start exploring the dynamics of the model in their own right. A final series of experiments has therefore explored the dynamics in the simulation when different 'worlds' are created, as a setup to more elaborate testing of hypotheses concerning systems of innovation (Nooteboom 1999a). These different worlds are defined in terms of the initialization of the strengths of the different values for $\alpha$ and $\tau$. Figure 4.9 shows how the
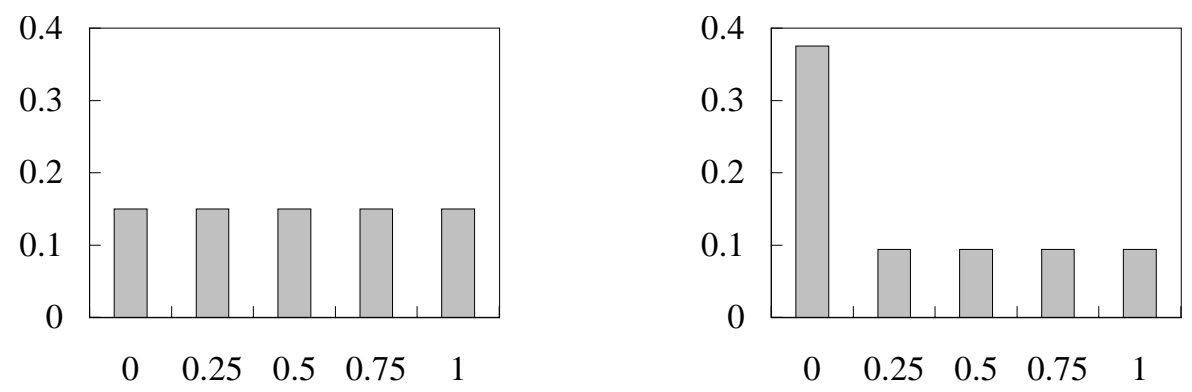

Figure 4.9: Different ways of initializing strengths.

strengths for the 5 possible values for $\alpha$ were initialized in the experiment $d=0.25$ reported above (on the left) and in the some of the experiments with $d=0.25$ reported below (on the right). When $d=0.25$, $C_{\alpha}=C_{\tau}=3 d=0.75$. In the previous experiments, this total was distributed evenly over the 5 possible values for $\alpha$, yielding absolute (relative) initial strenghts of $0.15(0.20)$ - for $\tau$, the same holds, except that 5 values between 0 and 0.5 were used, as explained above (Section 4.1). In the following experiments, the emphasis was either put on small or on large values for $\alpha$ and $\tau$. Half of $C_{\alpha}$ and $C_{\tau}$ was assigned to one extreme value, and the other half was distributed evenly across the remaining 4 values, as illustrated in the right-hand picture in Figure 4.9. Because relative rather than absolute strengths are used, the initial weighted average for low $\alpha$ is $0 \cdot 0.5+(0.25+0.5+0.75+1) \cdot 0.125=0.3125(0.6875$ for 
high $\alpha$ ) and $0.15625(0.34375)$ for low (high) $\tau$. Rather than at $(0.5,0.25)$ as above, the co-adaptive dynamics in the agents' problem spaces start at the four combinations of low and high weighted averages for $\alpha$ and $\tau$.

Figure 4.10 shows the buyers' adaptive walks in their search space of

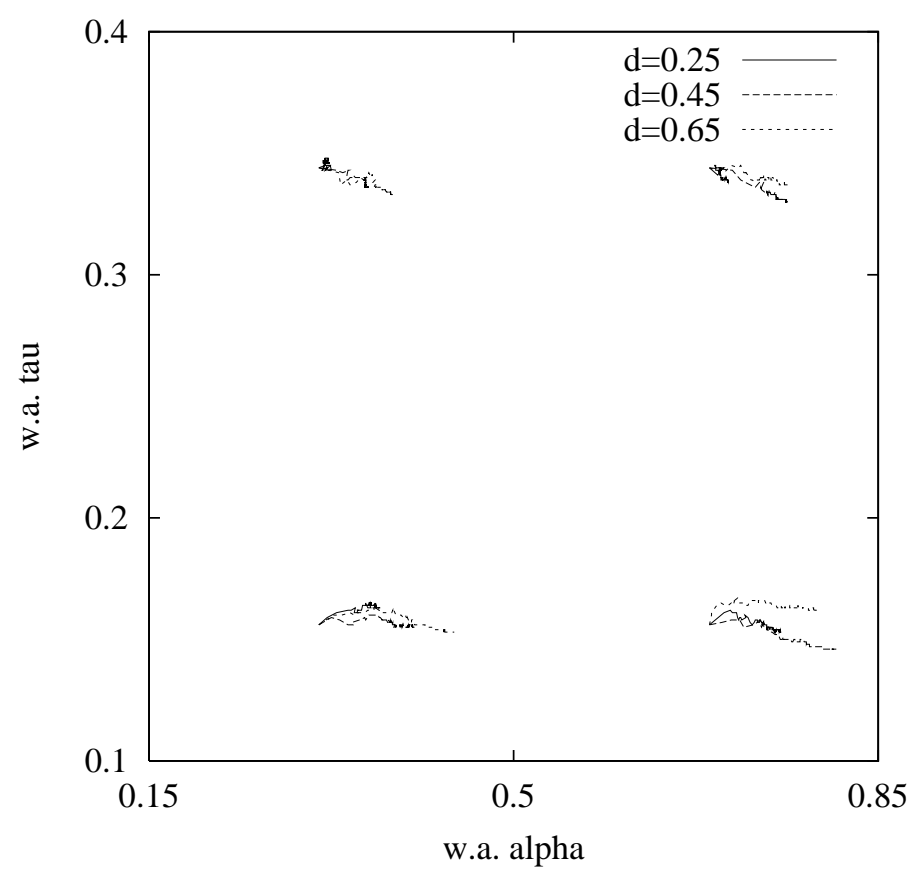

Figure 4.10: Buyers' adaptive learning in the space of $\alpha$ and $\tau$ in different experiments, starting from different initial positions.

weighted average $\alpha$ and $\tau$, averaged across all buyers in the population and across the 25 runs of each experiment. When analyzing the fact that the trajectories that the agents follow lead to higher values of $\alpha$, the following observation has to be taken into account. In all cases, outsourcing is more profitable than insourcing, no matter what the degree of product differentiation - it just takes time for this advantage to materialize when $d$ is high compared to when it is low, because when $d$ is high, higher profits are obtained as a result of economies of learning, which only increase over time. In order for buyers to outsource more and to become more 
profitable, therefore, suppliers have to become more attractive than buyers consider themselves, which means that buyers have to assign higher scores to suppliers than they do to themselves. The point is that if trust is higher than profitability, then low values for $\alpha$ yield the highest scores, while if trust is lower than profitability, the highest scores are obtained with high values for $\alpha$. The fact that the agents seem to be learning to use higher values for $\alpha$ indicates that trust increases more slowly than profitability. This also explaines why, over time, the agents learn to use higher values for $\alpha$ when $d$ is higher, since increases in profitability are more dependent on the passage of time in that case. In addition, it explains why the agents learn to use higher values for $\alpha$ when $\tau$ is low than when it is high, since if $\tau$ is low, there is more switching and less trust builds up, so buyers need to focus on suppliers' profitability rather than on their trust in them in order to consider them attractive.

Figure 4.10 shows the high-level trend in the trajectories of the individual agents. However, even more information than in Figure 4.8 is lost as compared to the plot for the individual agents (Figure 4.6). Individual agents wander about their own search space that is coupled to other agents' search spaces in a non-linear fashion. This 'process of becoming' at the level of the individual agents needs to be studied in order to gain insight into why agents behave the way they do. 


\section{Chapter 5}

\section{Discussion}

\subsection{Conclusions}

Experiments with the model show that important processes of marketmaking are overlooked in TCE. There, the market is proposed as a structure that can be used to organize transactions, while it is ignored that a market has to be made before it can be used. Efficient outcomes are assumed rather than investigated. With the simulation model presented in Chapter 3, however, outcomes can be investigated and understood as the result of the processes that lead to them. In addition, the experiments have shown the need for an analysis at the level of individual agents in order to gain real insight.

In particular, efficient outcomes arise only rarely; many more situations can and do arise than just the optimal ones. It takes a far greater deal of coordination to generate an optimal outcome than individual, boundedly rational adaptive agents are able to achieve among them. Absent a central coordinating agent, it was shown that it is more likely than not that a group of autonomous agents does not 'find' an optimal configuration. Individual agents build up long-lasting trust relations with others that stand in the way of the market's evolution to optimal configurations where economies of scale are fully exploited the way TCE assumes.

More generally, it has to be recognized that the process in which a market is made by the participants involved has important charac- 
teristics of its own. There have been several occasions where this has proved important. In particular, the importance of the fact that marketmaking takes time is higher when the advantage of the market depends on economies of learning than when it depends on economies of scale. On the other hand, the fact that the particular market that is made is just one of many possibilities and that they are not all equally efficient is more important when the advantage of the market depends on economies of scale than when it depends on economies of learning. These are considerations that standard TCE does not incorporate, so that it can never be able to explain some of the phenomena we have found and that are considered relevant in the explanation of organization.

While these conclusion force us to dismiss the (transaction cost) economics approach on the one hand, we now have an alternative approach that can be used to advantage for investigating issues of economic organization and many others, as demonstrated by the wider ACE-population. ${ }^{1}$ Global organizational regularities can be 'grown' and examined as the product of decentralized interactions among individual agents. Even though the experiments in the previous chapter have only scratched the surface of the possibilities, the usefulness of the approach has been demonstrated. Many more options remain to be investigated (see Section 5.3), but first, the current approach and model are put in some perspective.

\subsection{Discussion}

In the introduction, it was mentioned that all possible behavior-within the multi-dimensional space of possibilities set up in Chapter 3, that iswould be allowed. It was also mentioned, however, that the structure of the model makes it impossible to determine what the optimal behavior is. ${ }^{2}$ For all we know, the agents may actually have been behaving

\footnotetext{
${ }^{1}$ See the listing of ACE-researchers on the ACE-website at:

http://www.econ.iastate.edu/tesfatsi

${ }^{2}$ The optimum in the sense of each supplier supplying to his maximum number of allowed buyers and generating 'maximum' economies of scale is not behavior; it
} 
optimally. Notwithstanding the criticism of genetic algorithms given in Chapter 2, a GA can be used to estimate what the optimum is, as precisely the kind of useful benchmark that was suggested in (Klos 1999) and by Tesfatsion (2001, see Section 2.1.2). However, even though a GA was not employed here, results from experiments explicitly comparing a GA with individual learning as implemented in the current model (see also Klos 1999, Vriend 1998) do seem to support the conclusion that introspective, individual-based learning does not allow agents to reach levels of performance consistent with population-level evolution as implemented by a GA. Even though the loop has not been closed in this thesis, therefore, it may still be concluded that optimal forms of organization will often not be used and that the process-modeling approach applied in this thesis can yield important insights into the forms of organization that are used and into the reasons those forms rather than others are used. Additional experimentation can also give insights relevant for normative assessments of how to reach particular outcomes.

There are some elements of the model that deserve some discussion. First of all, what does the stability of matches resulting from the DCR algorithm imply about the relations between agents in our model? In other words, how plausible is it that only relations occur that are part of a set of stable matches? The DCR algorithm was used as a means to assign buyers to suppliers or to themselves and not because it yields stable matches, but it does nonetheless. In fact, the matching algorithm was only implemented because of dissatisfaction with the previous, custommade 'assignment algorithm' (Klos and Nooteboom 1998). A matching algorithm provides a neat way of performing this alignment, while the previous version was somewhat 'messy' and required a lot of additional assumptions that are already dealt with in the DCR algorithm.

Another point concerns opportunism, trust and loyalty. Opportunism does not really include 'guile', which is part of its definition. In our model, opportunism is defined as breaking a relation, i.e. a sequence of consecutive matches. If this is considered simple self-interest seeking,

specifies an optimal outcome, not which agent-behavior is required for them to attain that outcome. 
there is no real guile involved. A method for including guile, along with real transaction costs is suggested below. Furthermore, trust has a baselevel, while loyalty does not. An agent's loyalty can easily be zero, while other agent's trust in that agent can never be zero, even though zero loyalty does not mean that the agent automatically breaks the relation, but just that he does not value the relation intrinsically. More generally, trust and loyalty are specified quite differently in our model. This is due to path dependence; the model was specified initially with just trust, profit and $\alpha-\tau$ was incorporated later.

\subsection{Further Research}

It is clear that the surface of possibilities has only been scratched in this thesis. Many more options for extending the model and for further experimentation have been opened up, however. Some options are discussed below.

\section{Guile}

One may argue that the agents' behavior when breaking a relation, although self-interest seeking, does not include guile. In TCE, opportunism is defined as self-interest seeking with guile. Here, trust is trust in (good) intentions, as the complement of opportunism, which is bad intentions; trustworthiness is the absence of opportunistic behavior. An obvious extension of the model would include guile in the modeling of opportunistic behavior. This could be accomplished by letting agents, when they are matched, appropriate some of the returns from investments in specific assets. They could do this with a certain probability that would increase with the amount of these appropriable returns. Other agents' trust would then come to imply their subjective interpretation of the probability that another agent does not appropriate such returns, while another agent's breaking a relation is then relegated to simple self-interest seeking and goes unpunished in terms of trust. This allows contracts to be included in the model: an agent would want to invest in a contract to the extent 
that he does not trust his partner. This is a very straightforward way of including transaction costs. Trust would then be a way of economizing on transaction costs and this would allow an investigation of when trust pays and of how stable it is in a society of self-interest seekers.

\section{Adaptive Differentiation}

The buyers could be allowed to adapt the location of their product, in a very literal sense searching a landscape on a multi-dimensional space, namely the product characteristics space (Lancaster 1966, see Section 3.2.2). They could experiment with different values for $d_{i}$, the differentiation of their product. More differentiated products would require more specialized assets to be invested in and would allow costs to be saved by setting up long term relations. The question is then whether different agents focus on different market-segments and what effect this has on the relations they have with their suppliers.

\section{Multiple Components}

A more general version of the model would allow for the possibility of multiple components per product and for multiple sources per component. A buyer may then be matched to the same or to different suppliers for the production of the various components; a single supplier may attain economies of scope in the production of different components for the buyer (see Williamson 1981b, note 18, p. 1547), whereas multiple suppliers may gain (external) economies of cognitive scope in their production for the buyer (cf. Nooteboom 1992, Péli and Nooteboom 1997).

\section{Internal Organization}

In a more complete model, the assumption that buyers calculate their own scores using trust $=1$ may be interpreted as the trust they really have in (the intentions of) their own organization. This issue refers to problems of monitoring inside organizations and principle-agent theory. The organization needs to be broken up into its constituent components, just like economic systems have been broken up into individual firms 
in this thesis. An organization consists of multiple individuals and the organization's behavior needs to be explained as the result of the individuals' behavior within the organization (cf., for example, Masuch and LaPotin 1989, and Cyert and March's Behavioral Theory of the Firm).

\section{Durable Specific Assets}

With respect to TCE's fundamental transformation, the emphasis in the current model was put on the second option mentioned (between brackets) in Section 3.2.2. As mentioned there, the relative effects of investments in durable specific assets have been investigated using a previous version of the model, but that became too complex because of all the assumptions that had to be made regarding depreciation of assets. The issue is important though: a proper implementation allows dependence due to possible loss of specific investments to be modeled, and allows an investigation of the effectiveness of different regimes for the distribution of ownership and risk of specific investments. This is important because it brings the model closer to transaction cost economic models and therefore allows a more rigorous comparison of the performance of both types of models. 


\section{Appendix A}

\section{Genetic Algorithms}

A genetic algorithm (GA) is a computational technique that simulates evolution in the search for solutions to complex problems. These are ploblems with large spaces of potential solutions, characterized by nonlinearities. This means there is no linear relation between the performance of solutions as classified along the dimensions used for characterizing them. If there were linear relations, the optimal solution could easily be found by a simple hill-climbing algorithm. A GA assesses the performance of different solutions in parallel and uses the information about how different solutions perform to direct the search towards promising areas of the search space. Adapting the search is done by simulating evolutionary processes.

In particular, a GA works as follows. A population of potential solutions is created randomly and the algorithm then proceeds in a sequence of generations. In each generation, each of the solutions in the population is tested on the problem and given a fitness-score that expresses how well the solution performed in terms of solving the problem. When all solutions have been tested, poorly performing solutions are thrown away and a new generation is created by allowing highly successful solutions from the previous generation to reproduce. Two genetic operators are often used for this purpose: crossover and mutation. Crossover means that two solutions, often represented as strings of bits, are laid side by side, after which a point on the strings is chosen randomly and the substrings 
on the left (or right) of that point are swapped between the two strings. Mutation means that the offspring are changed slightly, usually by flipping bits (from 0 to 1 or vice versa) with a very low probability. Two offspring are created in this way that inherit features from each parent which ensures exploitation of features that made parents successful, but features of different parents are recombined and mutated for the purpose of exploration of new possibilities.

The original publication on genetic algorithms is (Holland 1975). More accessible introductions and handbooks are (Goldberg 1989) and (Davis 1991). Classic examples of applications of genetic algorithms to problems in social science include (Axelrod 1987) and (Miller 1996). 


\section{Appendix B}

\section{The Simulation Program}

\section{B.1 Agent-Based, Object-Oriented Programming}

The simulation was developed in the general-purpose, object-oriented programming language SIMULA (Birtwistle et al. 1973). The objectoriented paradigm is very well suited for agent-based modeling (see, e.g. McFadzean and Tesfatsion 1999, Epstein and Axtell 1996), and for realworld modeling in general, which was the philosophy underlying the development of SIMULA as the first object-oriented language. Although the original language (SIMULA I) was a SIMUlation LAnguage, the second and final version, SIMULA 67 (nowadays just called SIMULA), is a general-purpose language, and the acronym now stands for SIMple Universal LAnguage. Object-oriented technology 'simulates' the real-world, which gives it several desirable properties. Object-oriented programs are modular; the modules are described in classes. These serve as 'templates' for the creation (instantiation) of objects, which represent actual objects in the real world. Classes consist of declarations of data (properties, attributes) and methods (behavior) that operate on those data. Subclasses may be defined that inherit the data and methods of the superclass, and may be re-defined or supplemented with data and methods specific for the subclass. Objects may also send messages to other objects. Object- 
oriented programming thus consists of specifying classes. If a program is run, the objects interact with each other by sending messages.

\section{B.2 Specification}

The program consists of blocks at different levels. A block begins with 'Begin' and ends with 'End;'. Within a block, declarations go before statements. The global structure of the program is as follows (comments start with '!' and end with ';').

\section{Begin Program}

2. Class agent;

3. Begin

4. !declaration of variables;

5. !declaration of procedures;

6. End Class agent;

The program starts with the declaration of the class agent (line 2). It contains a number of data (variables) and methods (called procedures in SIMULA).

setAlpha This is the procedure that chooses a value to be used for $\alpha$, using a roulette wheel selection process. The wheel is divided like a pie in as many parts as there are possible values for $\alpha$, with the size of each part proportional to the relative strength of the associated value for $\alpha$, i.e. the appropriate value's strength divided by the total of all strenghts. The roulette wheel is spun like a wheel of fortune and the value for $\alpha$ at which the wheel stops is the one that is chosen.

setTau This is a procedure equivalent to the previous one that chooses a value to be used for $\tau$.

updateAlphaWeights (alphaUsed,payoff) This procedure is called for updating the strength of the value used for $\alpha$ (alphaUsed). This 
is done by adding the value of payoff to the appropriate value's current strength.

updateTauWeights (tauUsed, payoff) This is a procedure equivalent to the previous one that is used for updating the strength of the value used for $\tau$.

7. agent Class buyerAgent;

8. Begin

9 . . . .

10. End agent Class buyerAgent;

11. agent Class supplierAgent;

12. Begin

13. ....

14. End agent Class supplierAgent;

The class agent is used as a prefix in the declaration of two more classes buyerAgent (1. 7) and supplierAgent (1. 11), so that those two classes 'inherit' the class agent's data and procedures. These may be supplemented with data and methods declared within the subclass, to further specify subclasses and differentiate them from each other and from the superclass. In addition to the data and methods inherit from the class agent, the class buyerAgent contains the following procedures:

calculateSupplierScores This procedure calculate scores of suppliers and of the buyer himself as Cobb-Douglas functions of profitability and trust, as described above in Section 3.2.

increaseTrust (subject) This increases the buyer's trust in subject on the basis of the number of times they have been matched.

decreaseTrust (subject) This decreases the buyer's trust in subject.

buyerProcess If the buyer is not matched then he makes, and he sells his product in any case. The suppliers' equivalent supplierProcess is executed before the buyers', so if a buyer is matched to a supplier, that supplier will already have produced for him. 
Next to the procedures inherited from the class agent, the class supplierAgent contains the following procedures.

calculateBuyerScores This procedure calculates the scores the supplier assigns to each buyer.

determineScaleEfficiency Depending on the number of buyers he is matched to and the differentiation of their products, the supplier determines the scale-efficiency in using general-purpose assets.

climbLearningCurve(subject) On the basis of the number of times they have been matched before, the supplier calculates his efficiency due to learning-by-doing in using subject-specific assets.

increaseTrust (subject) This procedure increases the supplier's trust in subject on the basis of the number of previous times they have been matched.

decreaseTrust (subject) This procedure decreases the supplier's trust in subject.

produceFor (subject) Based on the differentiation of buyer subject's products and the supplier's scale- and subject-specific efficiency, the supplier produces for subject.

supplierProcess Looking at each buyer in turn, if a supplier is matched to that buyer, it produces for that buyer (see the previous procedure produceFor (subject)).

15. Procedure matchAgents;

16. Begin

17. ...

18. End procedure matchAgents;

Next is the declaration of the procedure matchAgents (1. 15), which implements the DCR algorithm. 
19. !declaration of variables;

20. !initialization;

Now the main loop of the program is entered, after some more variables are declared, such as experiment, run and timeStep (1. 19) and the simulation is initialized (1. 20). The number of buyers and suppliers in the simulation has to be supplied by the user, as well as the duration of the simulation (in timesteps) and the number of repetitions of each simulation (in runs), among others.

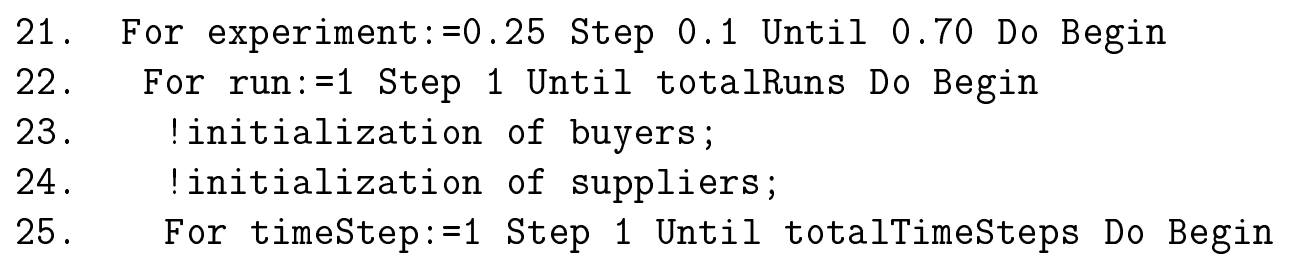

The actual simulation now begins. In this case, the experiments are hardcoded in the simulation (1. 21), in the form of different values for the variable experiment, which are then given to the variable differentiation of each buyerAgent. Within each experiment (the for-loop in line 21 is executed for each value of the experiment specified, i.e. $0.25,0.35, \ldots, 0.65$ ), a number of runs are executed (1. 22), in each of which, a number of timesteps is cycled through (1. 25). At the beginning of each run, the buyers and suppliers are re-initialized (1. 23-24), because their variables may still contain values from the previous run.

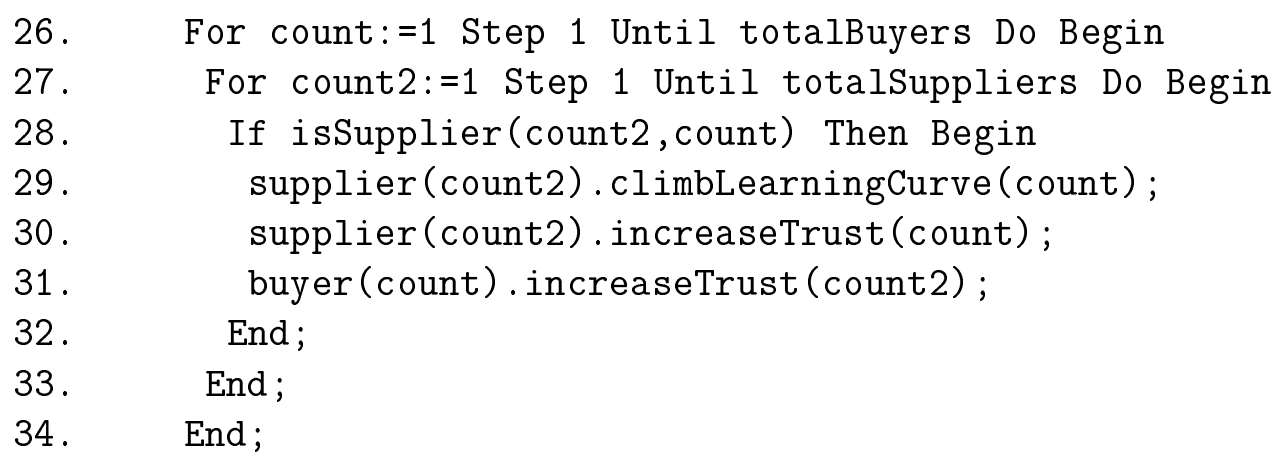


All possible combinations of agents are now examined (1. 26-27), to see whether they were matched to each other in the previous run. If they were, which is the case if the corresponding entry in the 2-dimensional boolean array, i.e. matrix is Supplier $(\cdot, \cdot)$ is True, then the supplier identified by the value of count2, climbs the buyer-specific learning curve for the buyer identified by count, (1. 29)) and they increase their trust in each other (1. 30-31).

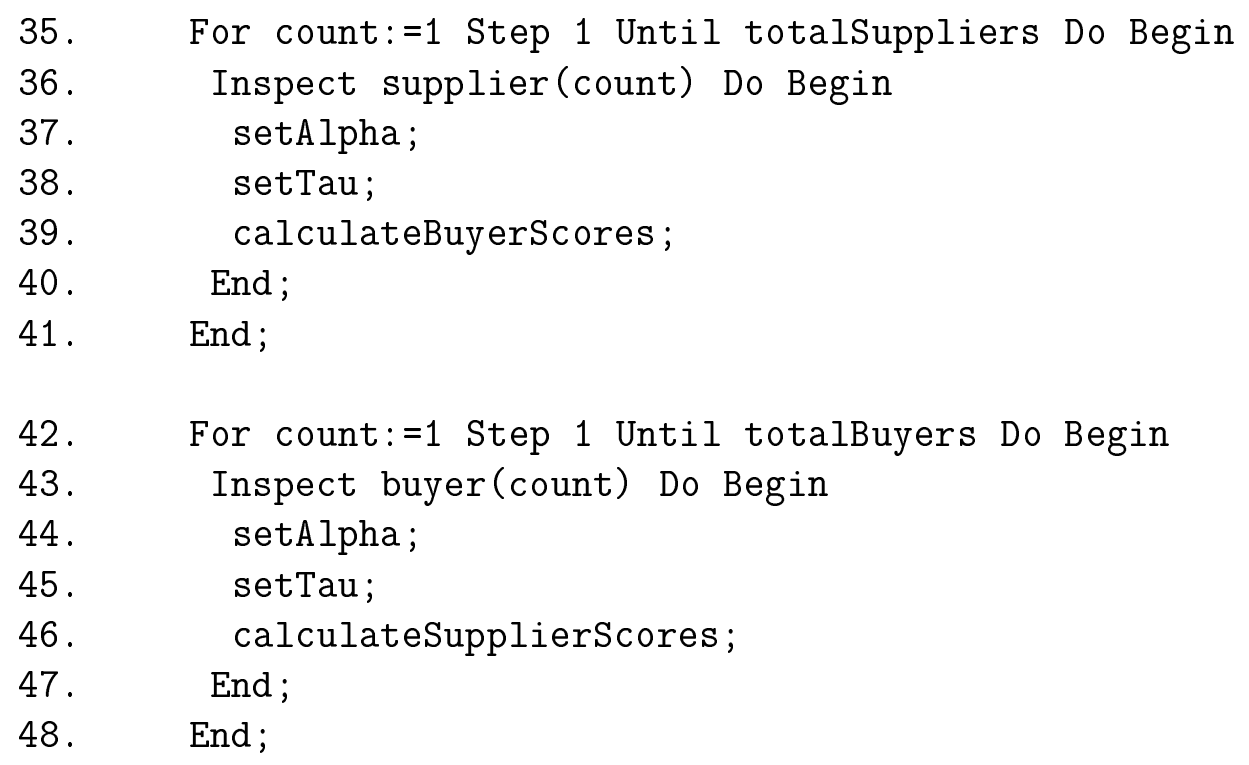

All suppliers now assign scores to all the buyers (1. 39) and all buyers assign scores to all suppliers plus themselves (1. 46). Before they do, however, they choose a value for $\alpha$ (1. 37 and 44) and for $\tau$ (1. 38 and 45).

49. For count:=1 Step 1 Until totalBuyers Do Begin

50. For count2:=1 Step 1 Until totalSuppliers Do Begin

51. wasSupplier (count2, count) :=isSupplier (count2, count) ;

52. is Supplier (count2, count) :=False ;

53. End;

54. End;

All connections from the previous timestep, stored in the boolean matrix isSupplier $(\cdot, \cdot)$, are now copied to the boolean matrix wasSupplier $(\cdot, \cdot)$ 
(1. 51), after which the first is emptied, i.e. set to False (1. 52). It will be re-filled on the basis of what happens during the matching.

55. matchAgents;

56. For count:=1 Step 1 Until totalBuyers Do Begin

57. For count2:=1 Step 1 Until totalSuppliers Do Begin

58. If requestSend (count, count2)

59. And Not hasRejected (count2, count)

60. Then Begin

61. isSupplier (count2, count) : =True ;

62. End Else Begin

63. If wasSupplier (count2, count) Then Begin

64. supplier (count2). efficiency (count) :=0;

65. If requestSend (count, count2) Then Begin

66. buyer (count). decreaseTrust (count2);

67. End Else Begin

68. supplier (count2). decreaseTrust (count);

69. End;

70. $\quad$ End;

71. End;

72. End;

73. End;

The procedure matchAgents is called (1. 55), which makes the agents establish strict preference-rankings on the basis of the scores they have just assigned, and matches them on the basis of those preference-rankings. All possible connections between buyers and suppliers are examined again (l. 56-57); if a request was send from buyer count to supplier count2 (1. 58 ), then they are matched (isSupplier (count2, count) is set to True; 1. 61) if the supplier did not reject that request (1. 59). Otherwise, the supplier drops off of his buyer-specific learning curve for buyer count-if he was on it (1. 63) - and the buyer decreases his trust in the supplier if he did send a request (1. 65-66), while the supplier decreases his trust in the buyer if the buyer did not send a request (1. 67-68). 


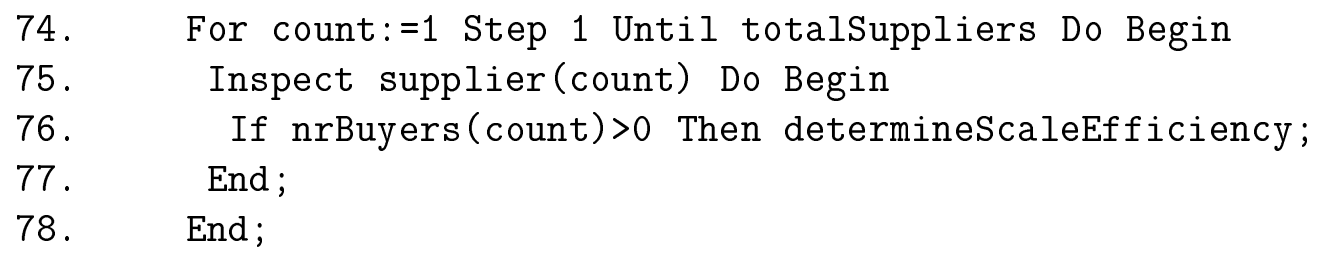

The buyers assigned scores to suppliers on the basis of their economies of scale in the previous timestep. Only after the matching, however, does it become clear to how many and to which buyers each suppliers is really matched, and what each supplier's real scale-efficiency is (1. 76).

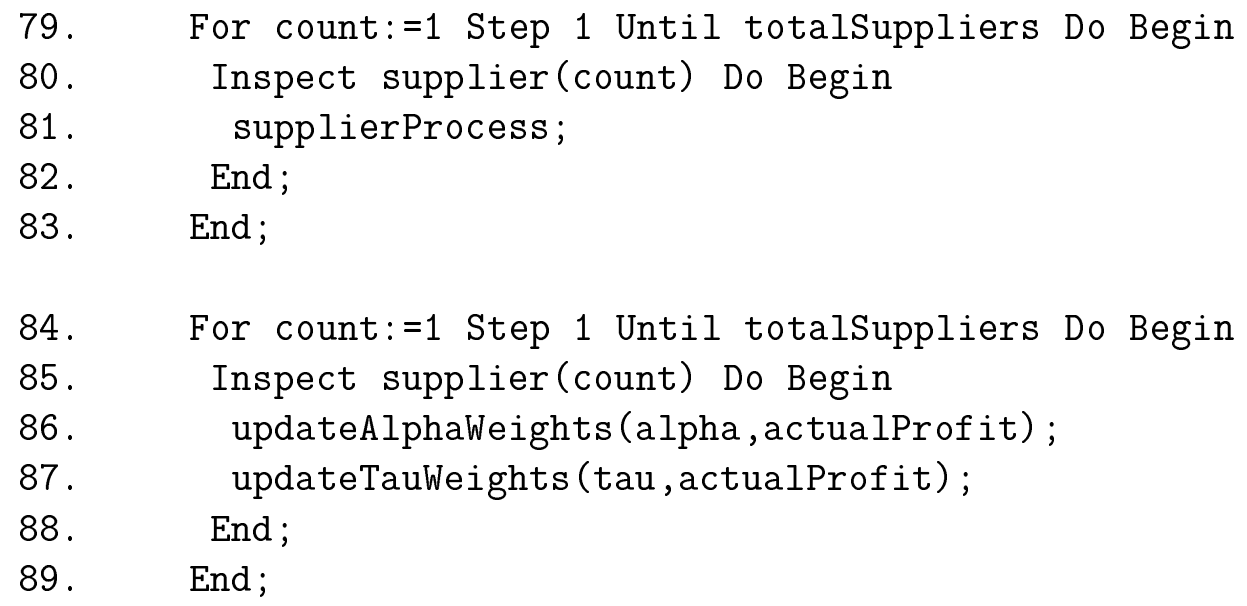

Each supplier now executes his main procedure, supplierProcess (1. 81). This procedure consists of producing for and supplying to all buyers the supplier is matched to. The fact that all suppliers have to execute their supplierProcess before each of them can update the strengths of the values used for $\alpha$ and for $\tau$, is a remnant from an earlier version of the simulation model that did not employ a matching algorithm as such (see Klos and Nooteboom 1998). In that model, what each supplier did affected the other suppliers' outlook for that timestep. The order in which the suppliers were activated was randomized for that reason (see Huberman and Glance's (1993) comments about synchronization of agent-interactions in relation to Nowak and May's (1992) computational prisoner's dilemma experiments). 
90. For count:=1 Step 1 Until totalBuyers Do Begin

91. Inspect buyer(count) Do Begin

92. buyerProcess;

93. updateAlphaWeights (alpha, actualProfit);

94. updateTauWeights (tau, actualProfit);

95. End;

96. End;

97. End timeStep-loop;

98. End run-loop;

99. End experiment loop;

100. End program;

Finally, the buyers execute their buyerProcess (1. 92), after which they update the strenghts of the values they used for $\alpha$ (1. 93) and $\tau$ (1. 94). During the course of the simulation, enormous amounts of data are written to files, and processed to produce graphs such as those in Chapter 4. 


\section{Appendix $\mathrm{C}$}

\section{Parameters and Variables}

\begin{tabular}{rlr} 
& parameter/variable & $\begin{array}{r}\text { value } \\
\text { range }\end{array}$ \\
\hline general & number of buyers, $I$ & $\{1,2, \ldots\}$ \\
& number of suppliers, $J$ & $\{1,2, \ldots\}$ \\
& number of runs, $R$ & $\{1,2, \ldots\}$ \\
& number of timesteps, $T$ & $\{1,2, \ldots\}$ \\
& number of values for $\alpha$ & $\{2,3, \ldots\}$ \\
& number of values for $\tau$ & $\{2,3, \ldots\}$ \\
& renormalization constant $C_{\alpha}$ & $\langle 0, \ldots\rangle$ \\
& renormalization constant $C_{\tau}$ & $\langle 0, \ldots\rangle$ \\
& baseTrust, $b$ & $\langle 0,1]$ \\
& initTrust(subject) & {$[0,1]$} \\
& trustFactor & {$[0,1]$} \\
\hline per & differentiation, $d_{i}$ & {$[0,1]$} \\
buyer $i$ & offer quota, $o_{i}$ & $\{1,2, \ldots, J\}$ \\
\hline per & acceptance quota, $a_{j}$ & $\{1,2, \ldots, I\}$ \\
supplier $j$ & scaleFactor & {$[0,1]$} \\
& learnFactor &
\end{tabular}

Table C.1: Parameters and variables allowed in the simulation. 


\section{Bibliography}

Albin, Peter S. and Duncan K. Foley (1992). Decentralized, dispersed exchange without an auctioneer: A simulation study. Journal of Economic Behavior and Organization 18(1), 27-51.

Alchian, Armen A. (1950). Uncertainty, evolution, and economic theory. Journal of Political Economy 58(3), 211-221.

Anderson, Simon P., André de Palma and Jacques-François Thisse (1992). Discrete Choice Theory of Product Differentiation. The MIT Press. Cambridge, MA.

Arthur, W. Brian (1991). Designing economic agents that act like human agents: A behavioral approach to bounded rationality. American Economic Review 81(2), 353-359.

Arthur, W. Brian (1993). On designing economic agents that behave like human agents. Journal of Evolutionary Economics 3(1), 1-22.

Arthur, W. Brian, John H. Holland, Blake LeBaron, Richard Palmer and Paul Tayler (1997). Asset pricing under endogenous expectations in an artificial stock market. In: The Economy as an Evolving Complex System, II (W. Brian Arthur, Steven N. Durlauf and David A. Lane, Eds.). Vol. XXVII of Santa Fe Institute Studies in the Sciences of Complexity Proceedings. pp. 15-44. Addison-Wesley. Reading, MA.

Axelrod, Robert (1984). The Evolution of Cooperation. Basic Books. New York. 
Axelrod, Robert (1987). The evolution of strategies in the iterated prisoner's dilemma. In: Genetic Algorithms and Simulated Annealing (Lawrence Davis, Ed.). pp. 32-41. Pitman. London.

Axtell, Robert L. (1999). The emergence of firms in a population of agents: Local increasing returns, unstable Nash equilibria, and power law size distributions. Working paper. Brookings Institution.

Birtwistle, Graham M., Ole-Johan Dahl, Bjørn Myhrhaug and Kristen Nygaard (1973). SIMULA Begin. Studentlitteratur. Lund, Sweden.

Blume, Lawrence E. and David Easley (1998). Optimality and natural selection in markets. Economics Working Paper 98-09-082. Santa Fe Institute.

Booker, Lashon B., David E. Goldberg and John H. Holland (1989). Classifier systems and genetic algorithms. Artificial Intelligence 40(13), 235-282.

Chiles, Todd H. and John F. McMackin (1996). Integrating variable risk preferences, trust, and transaction cost economics. Academy of Management Review 21(1), 73-99.

Coase, Ronald H. (1937). The nature of the firm. Economica NS 4(16), 386-405.

Coase, Ronald H. (1995). My evolution as an economist. In: Lives of the Laureates (William Breit and Roger W. Spencer, Eds.). pp. 227-249. The MIT Press. Cambridge, MA.

Dasgupta, P. (1988). Trust as a commodity. In: Trust: The Making and Breaking of Cooperative Relations (Diego Gambetta, Ed.). pp. 4972. Basil Blackwell. Oxford.

David, Paul A. (1985). Clio and the economics of QWERTY. American Economic Review 75(2), 332-337.

Davis, Lawrence (1991). Handbook of Genetic Algorithms. Van Nostrand Reinhold. New York. 
de Jong, Gjalt (1999). Causal Loops in Long-Term Supply Relations. Phd. thesis. Research Institute and Graduate School SOM. Groningen.

Deutsch, Morton (1973). The Resolution of Conflict: Constructive and Destructive Processes. Yale University Press. New Haven.

Enke, Stephen (1951). On maximizing profits: A distinction between Chamberlin and Robinson. American Economic Review 41(4), 566578.

Epstein, Joshua M. and Robert L. Axtell (1996). Growing Artificial Societies: Social Science from the Bottom Up. Brookings Institution Press/The MIT Press. Washington, DC/Cambridge, MA.

Friedman, Milton (1953). The methodology of positive economics. In: Essays in Positive Economics. pp. 1-43. The University of Chicago Press. Chicago, IL.

Gale, David and Lloyd S. Shapley (1962). College admissions and the stability of marriage. American Mathematical Monthly 69(January), 915 .

Gambetta, Diego (1988). Can we trust trust?. In: Trust: The Making and Breaking of Cooperative Relations (Diego Gambetta, Ed.). pp. 213237. Basil Blackwell. Oxford.

Glance, Natalie S. and Bernardo A. Huberman (1994). Social dilemmas and fluid organizations. In: Computational Organization Theory (Kathleen M. Carley and Michael J. Prietula, Eds.). pp. 217-239. Lawrence Erlbaum. Hillsdale, NJ.

Goldberg, David E. (1989). Genetic Algorithms in Search, Optimization and Machine Learning. Addison-Wesley. Reading, MA.

Gulati, Ranjay (1995). Does familiarity breed trust? The implications of repeated ties for contractual choice in alliances. Academy of Management Journal 38(1), 85-112. 
Hauk, Esther (1997). Leaving the prison: A discussion of the iterated prisoner's dilemma under preferential partner selection. Working paper. Universitat Pompeu Fabra.

Hill, Charles W.L. (1990). Cooperation, opportunism, and the invisible hand: Implications for transaction cost theory. Academy of Management Review 15(3), 500-513.

Holland, John H. (1975). Adaptation in Natural and Artificial Systems: An Introductory Analysis with Applications to Biology, Control and Artificial Intelligence. The MIT Press. Cambridge, MA.

Holland, John H. (1992). Complex adaptive systems. Daedalus 121(1), 17-30.

Holland, John H. and John H. Miller (1991). Artificial adaptive agents in economic theory. American Economic Review 81(2), 365-370.

Holland, John H., Keith J. Holyoak, Richard E. Nisbett and Paul R. Thagard (1986). Induction: Processes of Inference, Learning, and Discovery. The MIT Press. Cambridge, MA.

Huberman, Bernardo A. and Natalie S. Glance (1993). Evolutionary games and computer simulations. Proceedings of the National Academy of Sciences of the USA 90(16), 7716-7718.

Kirman, Alan P. and Nicolaas J. Vriend (2001). Evolving market structure: An ACE model of price dispersion and loyalty. Journal of Economic Dynamics and Control. forthcoming.

Klein, Benjamin, Robert G. Crawford and Armen A. Alchian (1978). Vertical integration, appropriable rents, and the competitive contracting process. Journal of Law and Economics 21(2), 297-326.

Klos, Tomas B. (1997). Spatially co-evolving automata play the repeated prisoner's dilemma. In: Simulating Social Phenomena (Rosaria Conte, Rainer Hegselmann and Pietro Terna, Eds.). Vol. 456 of Lecture Notes in Economics and Mathematical Systems. pp. 153-159. Springer. Berlin. 
Klos, Tomas B. (1999). Decentralized interaction and co-adaptation in the repeated prisoner's dilemma. Computational and Mathematical Organization Theory 5(2), 147-165.

Klos, Tomas B. and Bart Nooteboom (1998). Adaptive governance: The role of loyalty. Economics Working Paper 98-06-048E. Santa Fe Institute.

Klos, Tomas B. and Bart Nooteboom (2001). Agent-based computational transaction cost economics. Journal of Economic Dynamics and Control. forthcoming.

Kollman, Ken, John H. Miller and Scott E. Page (1992). Adaptive parties in spatial elections. American Political Science Review 86(4), 929937.

Koopmans, Tjalling C. (1957). Three Essays on the State of Economic Science. McGgraw Hill. New York.

Lancaster, K. (1966). A new approach to consumer theory. Journal of Political Economy 74(april), 132-157.

Lane, David A. (1993). Artificial worlds and economics, part II. Journal of Evolutionary Economics 3(3), 177-197.

Masuch, Michael and Perry J. LaPotin (1989). Beyond garbage cans: An AI model of organizational choice. Administrative Science Quarterly 34(?), 38-67.

McFadzean, David and Leigh S. Tesfatsion (1999). A C++ platform for the evolution of trade networks. Computational Economics 14, 109134 .

Miller, John H. (1989). The evolution of automata in the repeated prisoner's dilemma. Working Paper 89003. Santa Fe Institute.

Miller, John H. (1996). The coevolution of automata in the repeated prisoner's dilemma. Journal of Economic Behavior and Organization 29(1), 87-112. Originally published as (Miller 1989). 
Miller, John H. and Peter F. Stadler (1998). The dynamics of locally adaptive parties under spatial voting. Journal of Economic Dynamics and Control 23(2), 171-189.

Nooteboom, Bart (1992). Towards a dynamic theory of transactions. Journal of Evolutionary Economics 2(3), 281-299.

Nooteboom, Bart (1997). Will opportunism go away?. Research Report 97B06. Research Institute/Graduate School Systems, Organizations, Management. Groningen.

Nooteboom, Bart (1999a). Innovation and inter-firm linkages: New implications for policy. Research Policy 28, 793-805.

Nooteboom, Bart (1999b). Inter-Firm Alliances: Analysis and Design. Routledge. London.

Nooteboom, Bart (2000). Learning and Innovation in Organizations and Economies. Oxford University Press. Oxford.

Nowak, Martin A. and Robert M. May (1992). Evolutionary games and spatial chaos. Nature 359, 826-829.

Olson, Jr., Mancur (1965). The Logic of Collective Action: Public Goods and the Theory of Groups. Harvard University Press. Cambridge, MA.

Parkhe, Arvind (1993). Strategic alliance structuring: A game theoretic and transaction cost examination of interfirm cooperation. Academy of Management Journal 36(4), 794-829.

Péli, Gábor L. and Bart Nooteboom (1997). Simulation of learning in supply partnerships. Computational and Mathematical Organization Theory 3(1), 43-66.

Ring, Peter S. and Andrew van de Ven (1994). Developmental processes of cooperative interorganizational relationships. Academy of Management Review 19(1), 90-118. 
Roth, Alvin E. (1984). The evolution of the labor market for medical interns and residents: A case study in game theory. Journal of Political Economy 92, 991-1016.

Roth, Alvin E. and Marilda A. Oliveira Sotomayor (1990). Two-sided Matching: A Study in Game-theoretic Modeling and Analysis. Vol. 18 of Econometric Society Monographs. Cambridge University Press. Cambridge (UK).

Schelling, Thomas C. (1978). Micromotives and Macrobehavior. W.W. Norton \& Company. New York.

Sherstyuk, Katerina (1998). Efficiency in partnership structures. Journal of Economic Behavior and Organization 36(3), 331-346.

Stanley, E. Ann, Dan Ashlock and Leigh S. Tesfatsion (1994). Iterated prisoner's dilemma with choice and refusal of partners. In: Artificial Life III (Chris G. Langton, Ed.). Vol. XVII of Santa Fe Institute Studies in the Sciences of Complexity Proceedings. Addison-Wesley. Reading, MA. pp. 131-175.

Tesfatsion, Leigh S. (1997). A trade network game with endogenous partner selection. In: Computational Approaches to Economic Problems (Hans M. Amman, Berc Rustem and Andrew B. Whinston, Eds.). Vol. 6 of Advances in Computational Economics. pp. 249269. Kluwer. Dordrecht.

Tesfatsion, Leigh S. (2001). Structure, behavior, and market power in an evolutionary labor market with adaptive search. Journal of Economic Dynamics and Control. forthcoming.

Vriend, Nicolaas J. (1995). Self-organization of markets: An example of a computational approach. Computational Economics 8(3), 205-232.

Vriend, Nicolaas J. (1996). A model of market-making. Economics Working Paper 184. Universitat Pompeu Fabra. Barcelona. 
Vriend, Nicolaas J. (1998). An illustration of the essential difference between individual and social learning, and its consequences for computational analyses. Working Paper 387. Queen Mary and Westfield College, University of London. London.

Weisbuch, Gérard, Alan P. Kirman and Dorothea K. Herreiner (forthcoming). Market organisation and trading relationships. Economic Journal.

Williamson, Oliver E. (1971). The vertical integration of production: Market failure considerations. American Economic Review 61(2), 112-123.

Williamson, Oliver E. (1975). Markets and Hierarchies: Analysis and Antitrust Implications. The Free Press. New York.

Williamson, Oliver E. (1979). Transaction cost economics: The governance of contractual relations. Journal of Law and Economics 22(2), 233-261.

Williamson, Oliver E. (1981 a). The economics of organization: The transaction cost approach. American Journal of Sociology 87(3), 548-577.

Williamson, Oliver E. (1981b). The modern corporation: Origins, evolution, attributes. Journal of Economic Literature 19(4), 1537-1568.

Williamson, Oliver E. (1985). The Economic Institutions of Capitalism: Firms, Markets, Relational Contracting. The Free Press. New York.

Williamson, Oliver E. (1996). Transaction cost economics and the Carnegie connection. Journal of Economic Behavior and Organization 31(2), 149-155.

Winter, Sidney G. (1964). Economic "natural selection" and the theory of the firm. Yale Economic Essays 4(spring), 225-272. 


\section{Summary}

\section{Introduction}

This thesis is concerned with the organization of transactions. A transaction occurs when a good or service is transferred across a technologically separable interface, which is when one stage of activity terminates and another begins. There are different structural forms that can be used for organizing transactions. For example, both stages of activity that a transaction connects can be brought together within a single firm, in which case the firm's hierarchy is used to organize the transaction. Alternatively, the two stages can be distributed across different, specialized firms, in which case the market is used to organize the transaction. In more familiar terms, a firm has to decide between outsourcing and insourcing activities, i.e., between buying components on the market and producing them internally.

Chapter 1 describes the theoretical background for the research. Transaction cost economics (TCE) is often used to analyze the issue of make or buy, but many other questions of organizing as well. This theory originated in the paper The Nature of the Firm by Coase (1937) and was subsequently developed, among others, by Williamson $(1975,1985)$. Coase (1937, p. 390) wondered "why a firm emerges at all in a specialised exchange economy", and "why co-ordination is the work of the price mechanism in one case and of the entrepreneur in another" (1937, p. 389). According to Coase and transacion cost economics in general, the firm should not be studied in isolation as a production function to 
be optimized, but the transaction should be made the basic unit of analysis and the firm should be seen as one of several alternative ways to organize transactions. Costs are associated with transactions that vary with the characteristics of the transaction. Because organizational forms are differentially able to economize on those costs, different organizational forms are more suited for organizing transactions with particular characteristics than for others.

Transaction cost economics is about finding the most appropriatei.e., the economic - organizational form given the characteristics of a transaction. The relevant characteristics are the frequency of the transaction, the uncertainty surrounding it and the transactionspecificity of the assets invested in it. In its search for optimal, economic organizational forms, TCE assumes that people are boundedly rational as well as potentially opportunistic. The first assumption means that people are unable to gather as well as process all the information required to make optimal decisions. The second means that people do not simply seek self-interest, but that they may do so with guile, including "calculated efforts to mislead, distort, disguise, obfuscate, or otherwise confuse" (Williamson 1985, p. 47), and that differential trustworthiness is hard, if not impossible to predict.

\section{Motivation}

There are two main points on which we disagree with transaction cost economics. The first is that it hypothesizes that the optimal structural forms that result from its analysis are also the ones that are used for organizing transactions in reality, while the agents doing the organizing are explicitly assumed to be unable to perform the alignment of organizational forms with attributes of transactions. This issue is taken up in the second chapter. Our second point of disagreement with TCE is that the market is suggested as an alternative form to be used for organizing transactions, while in fact, a market has to be made before it can be used. The choice between make or buy is more appropriately framed as one among several alternative sources of supply, one of which is internal 
to the firm and some of which are external. There will be more information available about some alternatives than about others. This connects to TCE's view on opportunism which is based on the assumption "that some individuals are opportunistic some of the time and that differential trustworthiness is rarely transparent ex ante" (Williamson 1985, p. 64). In TCE, since it is hard to tell who will be opportunistic when, opportunism is always considered possible, and measures to counter its effects are always considered necessary.

The picture can be made clearer by introducting the distinction between room for and inclination towards opportunism (Nooteboom 1999b) and by considering that actual opportunism is a function of the two. TCE does not consider inclination towards opportunism, because "[i]nasmuch as a great deal of information about trustworthiness or its absence that is generated during the course of bilateral trading is essentially private information (...) knowledge about behavioral uncertainties is very uneven. The organization of economic activity is even more complicated as a result" (Williamson 1985, p. 59). In this thesis, however, the suggested increase in the complication of the organization of economic activity is not admitted as a justification for not addressing the relevant information about trustworthiness or its absence. Instead, individual agents are modeled, including their private information that they generate during the course of their bilateral exchanges with other individual agents.

Chapter 2 takes up our other point of disagreement with transaction cost economics, that it hypothesizes outcomes consistent with a rational analysis that the agents involved are assumed to be unable to carry out. This is not to say that those outcomes can not occur, because the agents may stumble upon them by accident or luck, for example; objections are raised against the argument underlying the hypothesis of efficient outcomes. This argument is one often used in economics more generally, that behavior consistent with inefficient outcomes will not occur because it does not survive on markets. However, markets are not totally efficient in weeding out suboptimal behavior and in producing only optimal behavior. For optimal behavior to survive, it has to be present in the first place, or be introduced during the selection process, which may not hap- 
pen because of barriers to entry. Even if the optimal behavior is present in the population, it has to be transferred from one agent to the next, which is not trivial and also not in the interest of the agent doing the transfer who may therefore try to sabotage this transfer.

Furthermore, the evolutionary natural selection argument is argued to be principally unsuited for described developments in economic systems. Drawing a parallel with an earlier critique (Klos 1999) of an application of a genetic algorithm, a computational model of an evolutionary processes, to the study of economic systems (Miller 1996), the appropriateness of the evolutionary metaphor is questioned. Agents typically only interact with other agents somehow close to them rather than with all other agents, and they are not given new behavior by an evolutionary process, but decide on changing their strategy themselves, based on a comparison with others close to them.

\section{An Agent-based Approach}

In order to cope with the two objections raised against (transaction cost) economics, an alternative, agent-based approach is proposed. This allows individual agents to trust and act upon their private knowledge and to make their own decisions about adapting their behavior in their search for better performance. The agents are allowed to adopt any possible form of behavior if they expect to benefit from it. They are also allowed to experiment and innovate and to make mistakes. In such a setting, it can be investigated whether-rather than assumed that - efficient outcomes arise. Because such systems of adaptive agents of any reasonable size are intractable analytically, we resort to computer simulations.

Chapter 3 describes the simulation model used. In each one of a sequence of timesteps, individual firms are confronted with the problem of organizing a transaction. On a final-goods market, they sell a product with a certain level of differentiation. They have to decide between making and buying a component required to produce their product. They do so in each of a number of timesteps, and base decisions in 
current timesteps on their experiences in previous timesteps, which are co-determined by the other agents' decisions.

Assets that a supplier invests in to produce the component for a buyer are specific to the transaction with the buyer to the extent that the buyer's product is differentiated. Suppliers may build up economies of scale in their accumulation of non-specific assets across the production for multiple buyers, and economies of learning in their continued, uninterrupted use of buyer-specific assets in their production for a particular buyer.

Buyers are assigned to a supplier (in which case they buy the component) or to themselves (in which case they make the component) on the basis of buyers' preferences for being matched to each one of a number of possible suppliers and to themselves and on the basis of suppliers' preferences for being matched to each one of the buyers. This is done by a so-called matching algorithm, i.c. Tesfatsion's (1997) Deferred Choice and Refusal (DCR) algorithm. Preferences are based on scores that agents assign to each other and on their loyalty for their current partner, if they have one. Loyalty means that the agents prefer their current partner over alternatives as long as the scores they assign to alternatives do not exceed the score they assign to their current partner by at least a certain threshold, $\tau$.

Scores are a function of profitability and trust: in essence, scores express expected profit - potential profit multiplied with the agent's trust in the other agent as an expression of the agent's subjective probability that the other agent will not behave opportunistically, but let him realize that potential profit. Because we want agents to be able to put differential weights on profitability versus trust, however, each agent raises other agents' profitability to the power of the value it uses for $\alpha$ and their trust to the power of $(1-\alpha)$. Buyers contribute to profitability through the positive effect that the differentiation of their products has on the returns they generate, while suppliers contribute to profitability through the negative effect that their economies of scale and learning have on the costs of production. Buyers are not able to produce with efficiency higher than 0 . Any profits made in a relation are shared among the two agents involved.

The agents' adaptation refers to the fact that they change their trust 
in other agents on the basis of their experiences in mutual interactions as well as the values they use for $\alpha$ and $\tau$. There are different values possible for each and in each timestep, when they need them for establishing preferences, the agents choose one value for each.

Chapter 4 presents and discusses the results from experiments with the model. First of all, a parametersetting has been chosen that make the results sensitive, but not too sensitive to changes in experimental variables. Then, the plausibility of the model was tested. A result from TCE that is not disputed here is the relation between increasing transactionspecificity of assets and an increasing proportion of economic activity that is organized internally rather than on the market. This relation was found in the results of a series of experiments in which the differentiation of the buyers' products on the final market was increased.

With some confidence in the model's sensitivity and plausibility, the two points of criticism of transaction cost economics could be dealt with. Concerning the investigation rather than assumption of efficient outcomes, it was established that the optimum is often not reached in a complex system of boundedly rational, adaptive agents. Only rarely does the system, by coincidence, develop a situation that is optimal for all agents involved. As for the second point of criticism, a direct comparison between TCE and our model is much harder, because TCE does not mention trust. It appears from the results that the agents learn to put slightly stronger emphasis on profitability than on trust. A more general conclusion that can be drawn from the results is that individual agents need to be investigated in order to understand what happens in the system. 


\section{Samenvatting (Summary in Dutch)}

\section{Inleiding}

Dit proefschrift gaat over het organiseren van transacties. Een transactie betekent dat een goed of dienst een technologische grens overschrijdt, wat het geval is als de ene activiteit ophoudt en de andere begint. Er zijn verschillende structuren waarin activiteiten kunnen worden georganiseerd. Beide activiteiten die door een transactie met elkaar worden verbonden kunnen bijvoorbeeld binnen één en hetzelfde bedrijf worden ondergebracht, in welk geval de hiërarchie binnen het bedrijf wordt gebruikt om de transactie te organiseren. De beide activiteiten zouden, aan de andere kant, ook over verschillende gespecialiseerde bedrijven kunnen worden verdeeld, in welk geval de markt wordt gebruikt om de transactie te organiseren. In wat bekendere terminologie moet een bedrijf besluiten activiteiten uit te besteden of zelf uit te voeren, dat wil zeggen om componenten zelf te maken of te kopen.

Hoofdstuk 1 beschrijft de theoretische achtergrond van het onderzoek. Transactiekostentheorie (TCE voor Transaction Cost Economics) wordt vaak gebruikt om het make-or-buy probleem te analyseren, maar ook voor vele andere organisatieproblemen. Deze theorie is ontstaan uit de publicatie The Nature of the Firm door Coase (1937) en verder ontwikkeld door, onder andere, Williamson $(1975,1985)$. Coase $(1937$, p. 390) vroeg zich af "why a firm emerges at all in a specialised exchange economy", 
en "why co-ordination is the work of the price mechanism in one case and of the entrepreneur in another" (1937, p. 389). Volgens Coase en de transactiekostentheorie in het algemeen, moet de onderneming niet in isolement worden bestudeerd als een te optimaliseren productiefunctie, maar moet de transactie eenheid van analyse worden gemaakt en moet de onderneming worden beschouwd als één van een aantal alternatieve manieren om transacties te organiseren. Aan het organiseren van transacties zijn kosten verbonden die variëren met de eigenschappen van transacties. Aangezien verschillende organisatievormen in verschillende mate in staat zijn op deze kosten te besparen, zijn sommige organisatievormen voor het organiseren van transacties met bepaalde eigenschappen meer geschikt dan (voor) andere.

Transactiekostentheorie gaat over het vinden van de meest geschiktedat wil zeggen de meest economische - organisatievorm, gegeven de eigenschappen van de transactie. Relevante eigenschappen zijn de frequentie van de transactie, de mate waarin de transactie door onzekerheid is omgeven en de transactiespecificiteit van activa. In de analyse van optimale, economische organisatievormen, veronderstelt TCE dat mensen beperkt rationeel zowel als mogelijk opportunistisch zijn. De eerste veronderstelling houdt in dat mensen niet in staat zijn alle voor optimale beslissingen benodigde informatie te verzamelen en te verwerken. De tweede veronderstelling houdt in dat mensen niet slechts hun eigenbelang nastreven, maar dat ze hierbij ook list en bedrog inschakelen, inclusief "calculated efforts to mislead, distort, disguise, obfuscate, or otherwise confuse" (Williamson 1985, p. 47), en dat individuele betrouwbaarheid moeilijk, zo niet onmogelijk vast te stellen is.

\section{Motivatie}

Op twee punten verschillen we met transactiekostentheorie van mening. Het eerste is dat TCE stelt dat de optimale structuren die resulteren uit haar rationele analyse ook de structuren zijn die in de werkelijkheid voor het organiseren van transacties worden gebruikt, terwijl tegelijkertijd degenen die organiseren expliciet verondersteld worden niet in staat 
te zijn organisatievormen optimaal op de eigenschappen van transacties af te stemmen. Op dit punt wordt in hoofdstuk 2 ingegaan. Ons tweede punt van kritiek is dat de markt wordt gesuggereerd als een van de alternatieve manieren die kunnen worden gebruikt om transacties mee te organiseren, terwijl een markt moet worden gemaakt voordat hij kan worden gebruikt. De keuze tussen kopen en zelf maken kan beter worden gezien als de keuze tussen een aantal alternatieve toeleveringsbronnen, waarvan er zich één binnen de onderneming bevindt en een aantal buiten de onderneming. Over sommige bronnen zal meer informatie beschikbaar zijn dan over andere. Dit sluit aan bij het perspectief van TCE op opportunisme, dat gebaseerd is op de assumptie "that some individuals are opportunistic some of the time and that differential trustworthiness is rarely transparent ex ante" (Williamson 1985, p. 64). Omdat het dus moeilijk te voorspellen is wie zich wanneer opportunistisch zal gedragen, wordt opportunisme altijd voor mogelijk gehouden en zijn maatregelen om negatieve effecten ervan tegen te gaan altijd nodig.

Het beeld kan worden verhelderd door het onderscheid tussen ruimte voor en neiging tot opportunisme te introduceren (Nooteboom 1999b) en zich te realiseren dat feitelijk opportunisme een functie van beide is. TCE beschouwt neiging tot opportunisme niet, omdat "[i]nasmuch as a great deal of information about trustworthiness or its absence that is generated during the course of bilateral trading is essentially private information (...) knowledge about behavioral uncertainties is very uneven. The organization of economic activity is even more complicated as a result" (Williamson 1985, p. 59). In dit proefschrift echter, wordt de gesuggereerde toename in de complexiteit van de organisatie van economische activiteit niet toegelaten als verantwoording voor het niet gebruik maken van relevante informatie over de aan- of afwezigheid van betrouwbaarheid. In plaats daarvan worden individuele actoren beschouwd, inclusief hun privé informatie die ze verzamelen tijdens hun interacties met andere actoren.

Hoofdstuk 2 gaat in op onze andere onenigheid met TCE, namelijk dat de theorie uitkomsten veronderstelt die consistent zijn met een rationele analyse die de betrokken actoren volgens de assumptie van be- 
perkte rationaliteit niet in staat zijn uit te voeren. Dit wil overigens niet zeggen dat dergelijke uitkomsten niet voor kunnen komen, aangezien de actoren er per ongeluk of toevallig voor zouden kunnen kiezen; ons bezwaar is gericht tegen het argument voor de hypothese van optimale uitkomsten. Dit argument wordt in de economische theorie vaak gebruikt, namelijk dat gedrag consistent met niet-optimale uitkomsten niet voor zal komen omdat het op markten niet overleeft. Markten zijn echter niet volledig effectief in het verwijderen van suboptimaal gedrag en het produceren van uitsluitend optimaal gedrag. Wil optimaal gedrag overleven, dan moet het aan het begin van dit evolutionaire proces al aanwezig zijn, of gedurende het proces tot stand kunnen komen, wat entreebarrières kunnen tegenhouden. Zelfs al is het optimale gedrag op zeker moment aanwezig, dan moet het van actor tot actor worden doorgegeven, wat een niet triviaal proces is en bovendien niet in het belang van de doorgevende actor, die het proces zal willen saboteren.

Afgezien van deze argumenten, wordt betoogd dat het evolutionaire natuurlijke selectie argument in het algemeen ongeschikt is voor het modelleren van ontwikkelingen in economische systemen. Aan de hand van een eerdere kritiek (Klos 1999) van een toepassing van een genetisch algoritme, een computationeel model van een evolutionair proces, voor het bestuderen van economische systemen (Miller 1996), wordt tegen de toepasselijkheid van de evolutionaire metafoor geargumenteerd. Actoren interacteren normaal gesproken alleen met bepaalde andere actoren in de 'groep' waartoe ze behoren en niet met alle andere actoren. Ze worden verder niet door een evolutionair proces nieuw gedrag gegeven, maar beslissen zelf over het aanpassen van hun gedrag, op basis van een vergelijking met anderen in de groep waartoe ze behoren.

\section{Een actorgebaseerde benadering}

Om met de beide punten van kritiek tegen transactiekostentheorie in het bijzonder en economische wetenschap in het algemeen om te kunnen gaan, wordt een alternatieve, actorgebaseerde benadering voorgesteld. Die benadering maakt het actoren mogelijk meer of minder vertrouwen 
in anderen te stellen, op basis van hun persoonlijke informatie over anderen te handelen en hun gedrag naar eigen goeddunken aan te passen in hun zoektocht naar betere prestaties. De actoren wordt het in principe toegestaan zich op elke mogelijke manier te gedragen, als ze menen daar beter van te worden. Het wordt ze ook toegestaan te experimenteren en te innoveren en fouten te maken. In een dergelijke omgeving kan worden onderzocht of -in plaats van verondersteld dat-optimale uitkomsten optreden. Omdat dergelijke systemen van adaptieve actoren met elke redelijke omvang niet analytisch te bestuderen zijn, is van computer simulaties gebruik gemaakt.

Hoofdstuk 3 beschrijft het gebruikte computersimulatiemodel. In elk van een reeks tijdsstappen, worden actoren geconfronteerd met het probleem een bepaalde transactie te organiseren. Ze verkopen een product dat in een bepaalde mate gedifferentieerd is. Ze moeten besluiten een component dat voor de productie van hun product nodig is te kopen of zelf te maken. Dit doen ze in elk van de tijdsstappen, waarbij ze beslissingen in huidige tijdsstappen baseren op hun ervaringen in vorige tijdsstappen, die deels worden beïnvloed door de beslissingen van andere actoren.

Activa waarin door een leverancier wordt geïnvesteerd ten behoeve van de productie van het component voor een bepaalde afnemer zijn specifiek voor de transactie met die afnemer in dezelfde mate waarin het product van de afnemer op de uiteindelijke markt gedifferentieerd is. Toeleveranciers kunnen schaalvoordelen opbouwen in niet-specifieke activa die ze gebruiken in hun productie voor meerdere afnemers en leervoordelen in hun continue, ononderbroken gebruik van afnemerspecifieke activa in hun productie voor die afnemer.

Afnemers worden aan een toeleverancier (in welk geval ze het component kopen) of aan zichzelf (in welk geval ze het component maken) toegewezen op basis van de preferenties van afnemers om aan elk van de toeleveranciers danwel aan zichzelf te worden toegewezen en op basis van de preferenties van de leveranciers om aan elk van de afnemers te worden toegewezen. Deze toewijzing wordt uitgevoerd door een zogenaamd toewijzingsalgoritme en meer bepaald door het Uitgestelde Keuze- en 
Weigerings- (DCR voor Deferred Choice en Refusal) algoritme. De preferenties zijn gebaseerd op scores die actoren aan elkaar geven en op hun loyaliteit voor hun huidige partner, als ze die hebben. Loyaliteit betekent dat actoren hun huidige partner prefereren boven alternatieven zolang de scores die ze aan alternatieven geven niet hoger zijn dan de score van hun huidige partner plus een bepaalde drempel, $\tau$.

Scores zijn een functie van winstgevendheid en vertrouwen; in essentie drukken scores verwachte winst uit — potentiële winst vermenigvuldigd met het vertrouwen in de andere actor als een uitdrukking van de subjectieve waarschijnlijkheid van de actor dat de andere actor zich niet opportunistisch zal gedragen en hem in staat zal stellen dat winstpotentieel ook daadwerkelijk te realiseren. Omdat we het de actoren echter mogelijk willen maken verschillend belang aan winstgevendheid versus vertrouwen te hechten, verheft elke actor de winstgevendheid van andere actoren tot de macht $\alpha$ en zijn vertrouwen in andere actoren tot de macht $(1-\alpha)$. Afnemers dragen aan winstgevendheid bij via het positieve effect dat de differentiatie van hun product heeft op de opbrengsten die ze genereren, terwijl leveranciers aan winstgevendheid bijdragen via het negatieve effect dat hun schaal- en leervoordelen hebben op de kosten van productie. Afnemers zelf kunnen geen schaal- of leervoordelen behalen. Alle winst die in een relatie tussen twee actoren wordt behaald wordt gedeeld.

Het adaptieve aspect van de actoren betreft het feit dat ze hun vertrouwen in andere actoren aanpassen op basis van hun ervaringen met die anderen en dat ze de waarden aanpassen die ze gebruiken voor $\alpha$ en $\tau$. Er zijn verschillende mogelijke waarden voor elk van beide parameters en in elke tijdsstap, als ze een waarde nodig hebben, trekken ze er een op basis van het succes dat ze in het verleden met de verschillende waarden hebben behaald.

Hoofdstuk 4 presenteert en bespreekt de resultaten van experimenten met het model. Ten eerste zijn parameterinstellingen gekozen die de resultaten van het model wel gevoelig, maar niet te gevoelig voor veranderingen in de variabelen maken. Vervolgens is een test van de plausibiliteit van de resultaten van het model gedaan. Een hier niet betwist 
resultaat van TCE is de relatie tussen stijging van de transactiespecificiteit van investeringen en stijging van het percentage activiteit dat intern wordt georganiseerd in plaats van uitbesteed. Deze relatie is gevonden in een serie experimenten waarin de differentiatie van de producten die afnemers op de uiteindelijke markt verkopen is opgevoerd.

Met enig vertrouwen in de gevoeligheid en de plausibiliteit van de resultaten van het model, zijn vervolgens de beide punten van kritiek op TCE behandeld. Wat de assumptie van optimale uitkomsten betreft, is vastgesteld dat het optimum in veel gevallen niet wordt bereikt, wanneer een systeem van adaptieve actoren allemaal hun eigen prestaties proberen te verhogen. Slechts in een enkel geval komt het systeem per toeval terecht in een situatie die voor ieder optimaal is. Wat het tweede kritiekpunt betreft valt een directe vergelijking veel moeilijker te maken tussen wat TCE stelt en wat er daadwerkelijk uit het model komt, omdat TCE over vertrouwen en loyaliteit helemaal niets zegt. Het blijkt uit de resultaten dat de actoren een licht sterkere nadruk leren te leggen op winstgevendheid dan op vertrouwen. Een algemene conclusie is dat, teneinde te begrijpen wat er in het systeem gebeurt, de analyse op het niveau van individuele actoren plaats dient te vinden. 


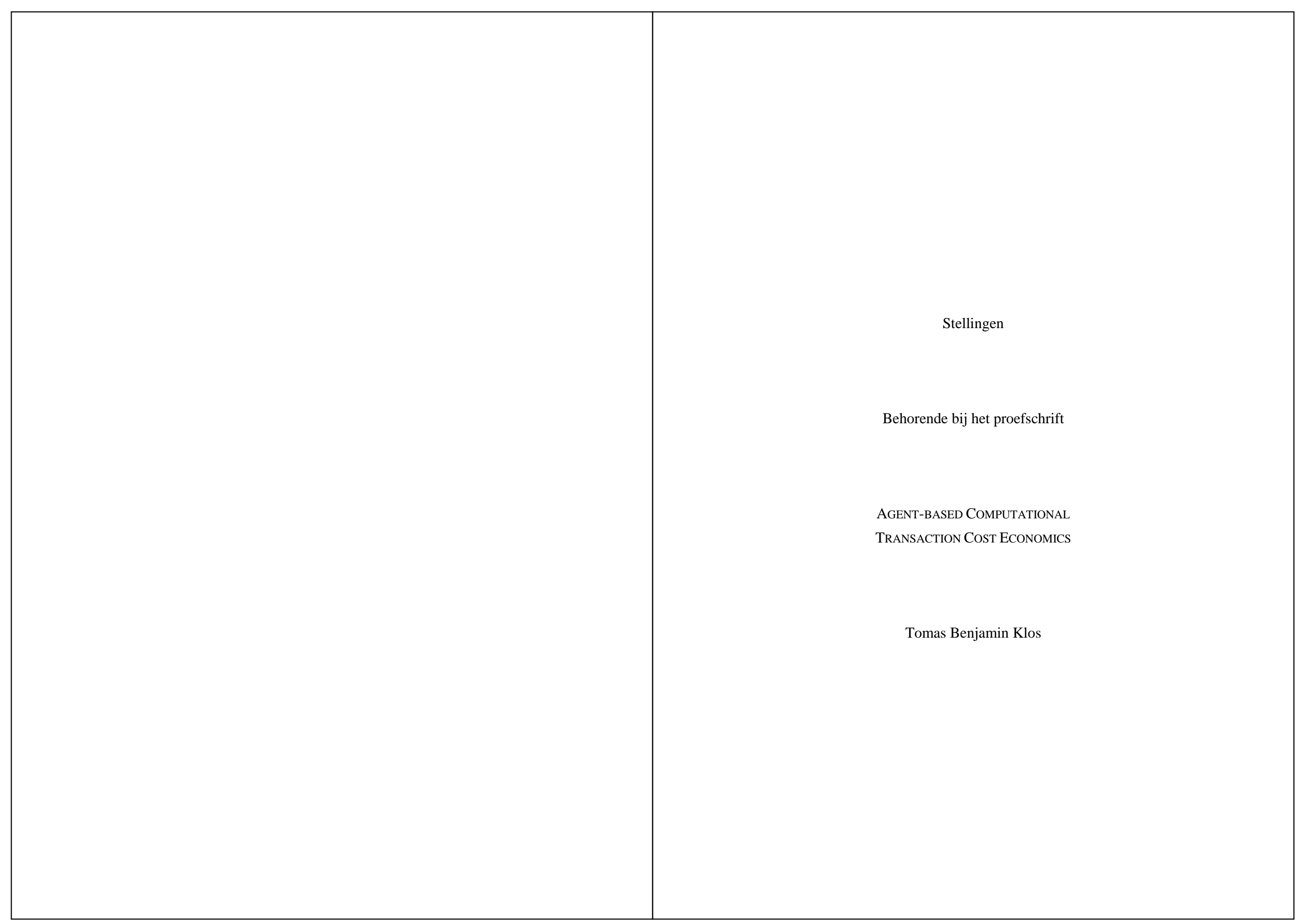


1. Loyaliteit staat efficiënt organiseren in de weg (dit proefschrift, hoofdstuk 4)

2. Het evolutionaire argument kan niet gebruikt worden om rationele analyses van optimale uitkomsten te rechtvaardigen (dit proefschrift, hoofdstuk 2).

3. Uitkomsten van simulatie-experimenten worden te vaak ten onrechte als verrassende resultaten ('emergent phenomena') bestempeld. Dit kan voorkomen worden door van te voren het model goed te analyseren en na te denken over wat verwacht mag worden.

4. Het feit dat aan een promotie-traject alleen al wordt begonnen duidt op noodzakelijke, maar niet noodzakelijk op voldoende bekwaamheid.

5. Elk promotie-traject voert over zijn eigen, specifieke fitness-landschap. De-tijdens het onderzoek zeer bruikbare-kaart van dit landschap kan pas aan het eind van het traject worden opgemaakt.

6. In de organisatie van aio-projecten wordt te weinig rekening gehouden met het spanningsveld dat ontstaat door de scheiding van het eigendom van en de controle op dergelijke projecten.

7. Teneinde het gevoel van eigendom over een project bij een aio te vergroten, verdient het aanbeveling aio's hun eigen onderzoeksvoorstel te laten schrijven.

8. Het feit dat de verlaging van transactiekosten door het toepassen van moderne informatie- en

communicatietechnologie minder groot is dan hij zou kunnen zijn, heeft een psychologische en geen technische oorzaak.
9. In de discussie over het al dan niet op geautomatiseerde wijze verzamelen van gegevens over het gedrag van internetgebruikers wordt te weinig rekening gehouden met de voordelen in termen van het afstemmen van

dienstverlening op de (latente) behoeften van gebruikers en te veel gewezen op het vermeende big-brother karakter hiervan.

10. De stelling dat volgens randstedelingen de afstand van Groningen naar de Randstad kleiner is dan de afstand van de Randstad naar Groningen, is alleen in de Randstad als stelling de moeite waard.

11. De enige goede aio is geen aio. 